مجلة كلية التربية بالإسماعيلية - العدد الأربعون - يناير 1^ ب r

دراسة إثنوجرافية لمجالس الأمناء والآباء والمعلمين في ضوء مدخل

\title{
لامركزية الإدارة
}

إعد)

د/ هند سيد أحمد الثوربجي*

مقدمة

يعيش الأفراد في مجتمع، تربطهم علاقات ومصالح، ويتفاعلون مع بعضهم البعض بطرق

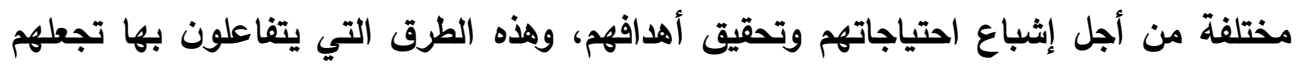

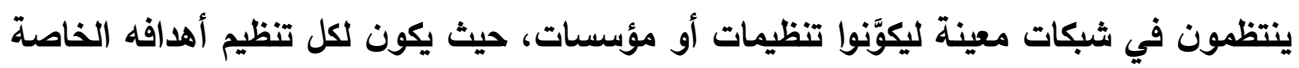

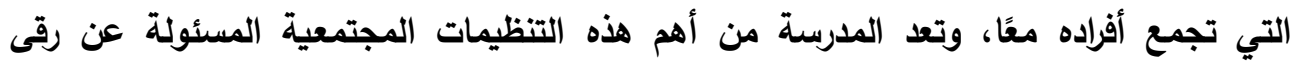
المجتمع وازدهاره من خلال حصول أفراد المجتمع على مستوى تعليمي معين. ومن هنا يمكن القول إن المجتمع مسئول عن التعليم، كما أن المدارس التي يتم بها التعليم من أجل المجتمع؛ لايها مسئولية تجاه المجتمع؛ لذلك توجد علاقة وثيقة بين المجتمع والمدرسة. وفي إطار توطيد هذه العلاقة وتفعيل الشراكة بين المدارس وأولياء الأمور والمجتمع، وسعيًا

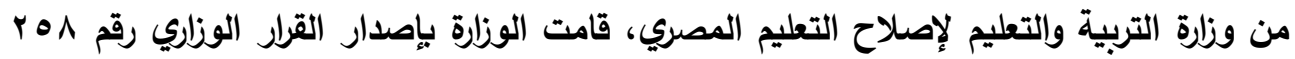

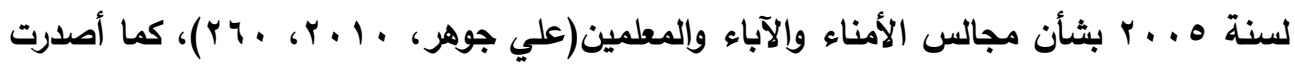

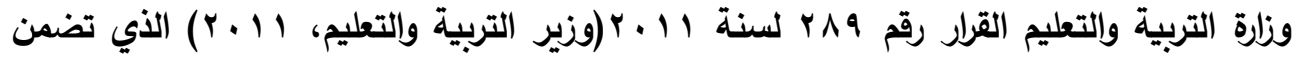
إنثاء مجلس للأمناء والآباء والمعلمين بكل مدرسة، وبكل إدارة تعليمية، وبكل مديرية تعليمية، وكذلك تكوين مجلس أعلى للأمناء والآباء والمعلمين بوزارة التربية والتعليم، وتحديد أهداف هذه المجالس. فالمشاركة الجماعية المنظمة بالمجتمع يكون عائدها أكبر وأوسع من المبادرات الفردية (محمد

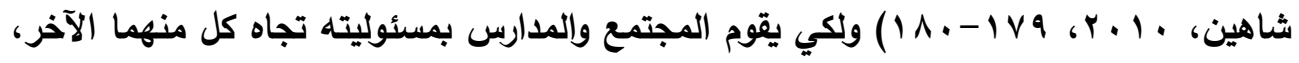
كان على مجالس الأمناء والآباء والمعلمين كتنظيم ممثل للمدرسة والمجتمع أن تقوم بلورها والأي يمثل مسئوليتها في إطار علاقة كل من المدرسة بالمجتمع. مدرس الإدارة التربوية - كلية الدراسات العليا للتربية - جامعة القاهرة 
وعلى الرغم من أهمية العلاقة والمسئولية المتبادلة بين تنظيمات المجتمع لتحقيق أهدافه،

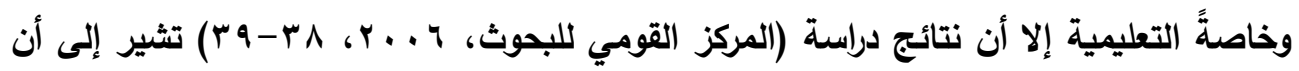

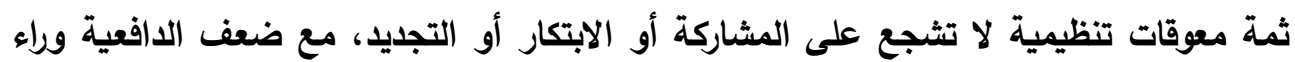
حركة المشاركة المجتمعية، نتيجة لضعف فهم الهرف الحقيقي من عمليات المشاركة.

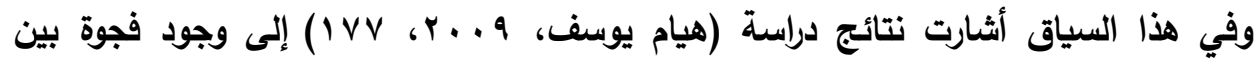
المدرسة والمجتمع المحلي، وأرجعت ذلك إلى عدة أسباب منها: ضعف الاتصال بينهم، وقلة المعلومات المتوفرة عن المدرسة ومشكلاتها لدى أعضاء المجتمع المحلي، وإنخفاض المدئ الوعي بدور المدرسة لاى المجتمع، وإنخفاض الوعي بدور المؤسسات المجتمعية وما تقوم به من

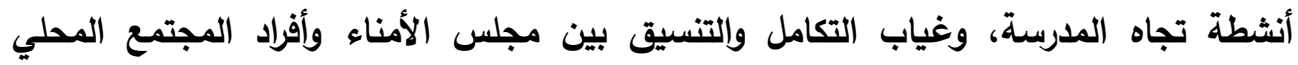
والمدرسة، وضيق الوقت وكثرة المشاغل لاى أفراد المجتمع المحلي، واعتقاد الأهالي بأن النياء التبرعات لا توجه إلى المجالات التي خصصت لها، وإنففاض مشاركة أعضاء المجتمع المحلي في صنع القرار داخل المدرسة، وأن هذه المشاركة قاصرة على فئات معينة مثل بعض أولئ أولياء الأمور ذوي النفوذ، وأنها محدودة تقف عند مجرد تقديم المشورة وإبداء الرأي فقط، كما أوضحت فئه فئه هذه الدراسة أن مشاركة بعض أولياء الأمور غير إيجابية لأن هدفها محدد لخدمة التلميذ فقط

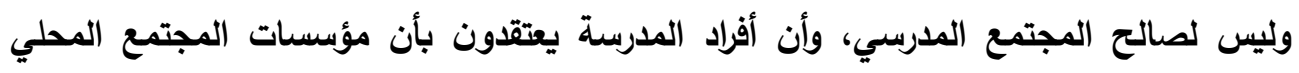
ليس لايها الخبرة بأسلوب التربية والتعليم، وبالتالي فهي تحتاج منها المشورة فقط.

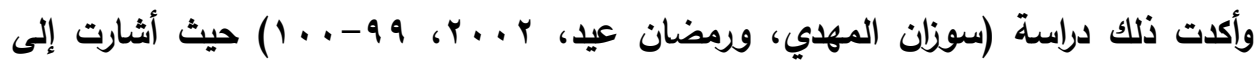
غياب الوعي بأهمية التكامل بين كافة الأطراف المعنية بأمور التعليم، وضعف التنسيق فيما بينها، وأيضا قلة مشاركة التنظيمات الثعبية على المستوى القومي في رسم السياسة التعليمية في المجتمع المصري، وهو ما يعني في المحصلة النهائية أن السلطة التعليمية المركزية تستأثر وحدها- في أكثر الأحوال - بتحديد الأهداف المجتمعية للسياسة التعليمية.

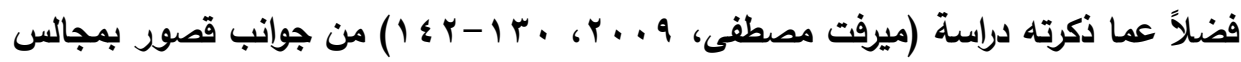
الآباء في القيام بدور فعال للربط بين المدرسة والمجتمع، والتي أوضحت أسبابها في قلة اهتمام

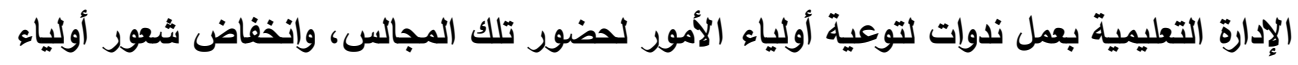
الأمور بمدى هذه الأهمية، وأن الوزارة لا توفر الدعم المادي لمجالس الآباء، وأن ندرة استجابة الأبهاء

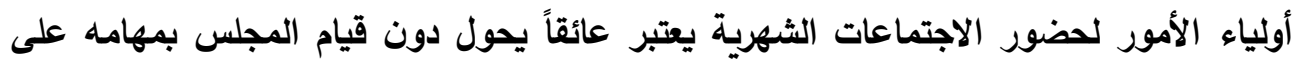


مجلة كلية التربية بالإسماعيلية - العدد الأربعون - يناير 1^ ب r

أكمل وجه، وأن معظم المدارس لا تضع خطة واضحة للربط بين المدرسة والأسرة، كما أضافت أن من أهم السلبيات لمجلس الأمناء: أنه تم فرض أسماء من المحليات ليس لهان الها علاقة بالعملية التعليمية، وأنه تم تهميش دور مدير المدرسة وأصبحت الرئاسة من خارج المدرسة مما يحد من من من مات إتاحة عرض الاحتياجات المطلوبة والعمل أحيانا على غير صالح المدرسة. ومن هنا تكون الدراسات السابقة قد أكدت وجود عدد من التحديات التي تواجه مجالس الأمناء والآباء والمعلمين، والتي أغلبها تحديات أو معوقات إدارية. ومن هنا يتبين الحاجة إلى تبني مدخل إداري يساعد على التظلب على هذه المعوقات والمثكلات، حيث أكلات بعض الاراسات

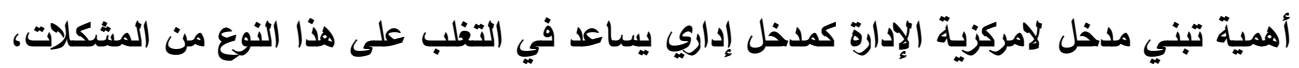
وأهميته في تطوير التعليم والنهوض بله، خاصة بمشاركة المجتمع الخارجي بما يحقق مسئولية

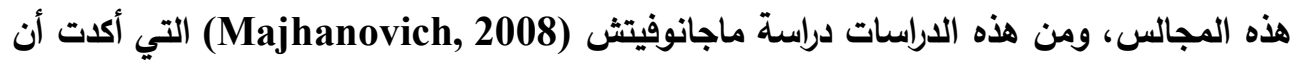
اللامركزية توفر مدى كبير من الإتاحة والايمقراطية في نظام التعليم، وأن اللامركزية تنجح عندما

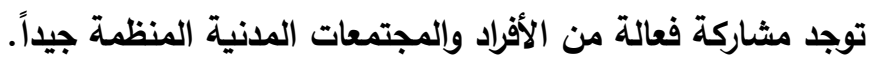

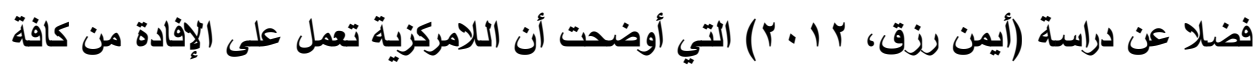
الموارد والقدرات والطاقات للعمل بكفاءة، وتعمل على تعزيز الكفاءة والثفافية والمساءلة في تقديم الخدمات التعليمية على المستوى المحلي، وتعطي المعلمين والآباء والمديرين مساحة أكبر من السلطة في صنع واتخاذ القرار، وأن التحول إلى اللامركزية في إدارة النظم التعليمية أصبح من

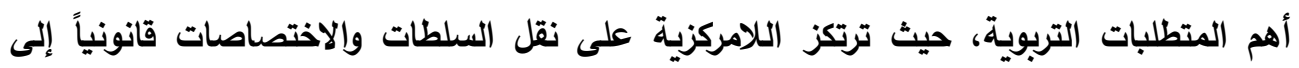
السلطة المحلية. وهنا تتأكد الحاجة إلى تعرف واقع إدارة مجالس الأمناء والآباء والمعلمين؛ من أجل وضع مجموعة من البدائل والآليات المقترحة لتطوير إدارة هذه المجالس في ضوء مدخل لإمركزية الإدارة، وبما يساهم في تحقيق مسئولياتها بالتعليم. مشكلة الاراسة وأسئلتها:

باستقراء نتائج الدراسات السابقة يتضح أن مجالس الأمناء والآباء والمعلمين تنظيمات أنشأها أفراد المجتمع لتحقيق أهدافه؛ حيث تساهم هذه المجالس في تحقيق الأهداف الاجتماعية عامةً، والأهداف التعليمية بصفة خاصة، وأن هناك قصورًا في تحقيق هذه المجالس لمسئولياتها، وأن من أهم أسباب هذا القصور هو مشكلات ومعوقات إدارية تنظيمية. 
دراسة إثنوجرافية لمجالس الأمناء والآباء والمعلمين --------- د / هند سيد أحمد

لذلك تسعى الدراسة الحالية إلى تفعيل دور مجالس الأمناء والآباء والمعلمين في تحقيق مسئولياتها بالتعليم للتفلب على هذا القصور من خلال استخدام أحد المداخل الإدارية الحديثة وهو لامركزيـة الإدارة.

وللتصدي لهذه المشكلة تحاول الدراسة الحالية الإجابة عن الأسئلة الآتية: كيف يمكن تحقيق مسئوليات مجالس الأمناء والآباء والمعلمين بالتعليم في ضوء مدخل

$$
\text { أهداف الدربية الإدارة؟ }
$$

هدفت الاراسة الإجابة عن الأسئلة الفرعية الآتية: 1. ما مسئوليات مجالس الأمناء والآباء والمعلمين ومعوقات تحقيقها؟ r. ما الأطر النظرية لمدخل لامركزية الإدارة لمجالس الأمناء والآباء والمعلمين؟

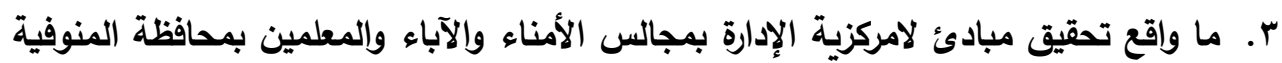
(دراسة إثنوجرافية)

ء. ما البدائل والآليات المقترحة لتطوير إدارة مجالس الأمناء والآباء والمعلمين في ضوء مدخل لامركزية الإدارة؟ أهمية الارراسة: تتمثل أهمية الاراسة النظرية والتطبيقية في الآتي:

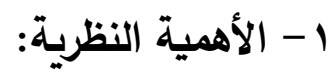
- تستمد الدراسة أهميتها من أهمية المؤسسة التربوية والمجتمعية (المدرسة) والتي يتوقف عليها إعداد المواطن القادر على تحمل المسئولية وذلك للنهوض بالمجتمع. - تنبع أهمية الدراسة النظرية من أهمية الموضوع الذي تتناوله وهو مسئولية مجالس الأمناء

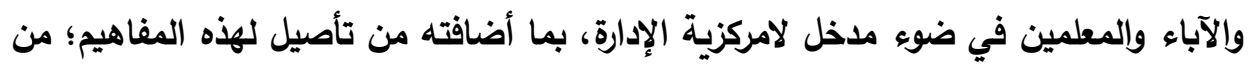
شأنها أن تعظم الإفادة من هذه المفاهيم بجميع تنظيمات المجتمع، وبصفة خاصة المنوطة والمهتمة بالتعليم؛ بما يساعد في النهاية على تحقيق الأهداف المجتمعية عامةً والتعليمية خاصةً. كما تساعد الباحثين المهتمين بهذا بها المجال. 
مجلة كلية التربية بالإسماعيلية - العدد الأربعون - يناير 1^ ب r - قد تساهم الدراسة في التحديد الدقيق لمجالس الأمناء والآباء والمعلمين بالتعليم، وتحديد معوقات تحقيقها لمسئولياتها؛ بما يفيد الباحثين المهتمين بهذه المجالس. - تستمد الدراسة أهميتها من خلال ما توصلت إليه من مبادئ وآليات لمدخل لامركزية الإدارة؛ تفيد به القيادات وإلباحثين المهتمين بهذا المدخل. r - الأهمية التطبيقية: - من المأمول أن تعمل الدراسة على تطوير الكفاءات الإدارية لمجالس الأمناء والآباء والمعلمين من خلال تطوير الأساليب الإدارية التي يستخدمونها مما يساعد على تحقيق الأهداف المنوطة بهم على أكمل وجه ويتم ذلك باستخدام مدخل لامركزية الإدارة.

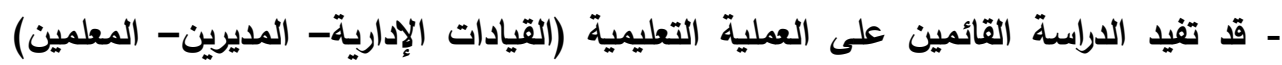
وأعضاء المجتمع المحلي، من خلال تطبيق البدائل والآليات المقترحة وفقاً لمدخل لامركزية الإلية الإدارة؛ بما يساعد في تحقيق الأهداف التعليمية. - قد تفيد الدراسة واضعي السياسات ومتخذي القرارات التعليمية في وضع واتخاذ القرارات التي تفَعِّل دور مجالس الأمناء والآباء والمعلمين وتساعدها على تحقيق مسئولياتها ولتحقيق الأهداف التربوية عامة. حدود الدراسةة: اقتصرت الدراسة على الحدود الآتية: الحدود الموضوعية: وضع بدائل وآليات مقترحة لتطوير إدارة مجالس الأمناء والآباء والمعلمين، لتعزيز مسئولياتها بالتعليم في ضوء مدخل لامركزية الإدارة. الحدود البشريـة : أعضاء مجالس الأمناء والآباء والمعلمين ببعض المدارس. الحدود المكانية: تم اختيار محافظة المنوفية لأنها إحدى محافظات الوجه البحري، لها طبيعة متشابهة مع كثير من محافظات الجمهورية مما قد يساعد في تعميم نتائج الاراسة مع وضع في الاعتبار بعض الظروف الخاصة من مقدار ما يتوافر لديها من إمكانات وموارد مقارنةً بالمحافظات الأخرى. 
دراسة إثنوجرافية لمجالس الأمناء والآباء والمعلمين --------- د / هند سيد أحمد

$$
\text { منهج الاراسة: المنهج الإثنوجرافي }
$$

اعتمدت الاراسة على منهج البحث الإثنواجرافي الذي يعتمد على الطرق والأساليب الكيفية في

الوصف التحليلي للظواهر الاجتماعية وعلاقتها بغيرها من الظواهر داخل المجتمع، وصولا لحقيقة

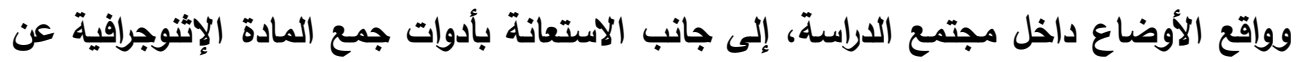
طريق الاستعانة بطرق وأدوات المنهج الإثنواجرافي، والتي تمثلت في الاعتماد على إجراء

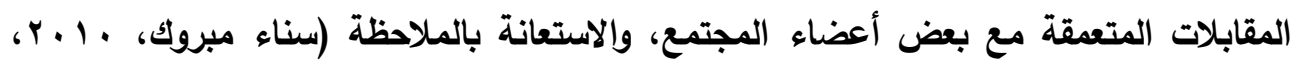

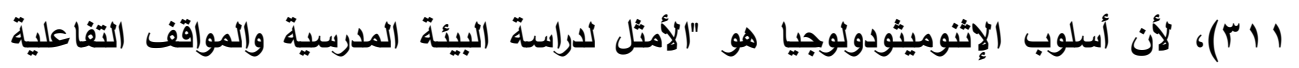
داخلها بين المعلمين والطلاب، والمعلمين والإدارة، والطلاب والطلاب، والمعلمين والمعلمين، والإثنوميثودولوجيا أسلوب بحثي، تمت استعارته من الأنثروبولوجي، وهو من الأساليب الكيفية في البحث الاجتماعي، الذي يقوم على المعايثة مع الجماعات الصغيرة لمدة طويلة موظفاً أدوات

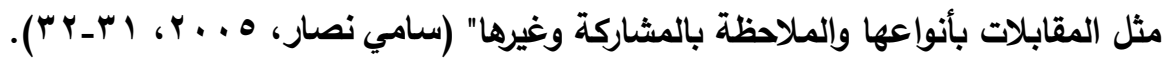

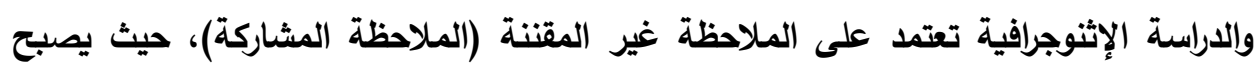
الباحث عضواً في الجماعة التي يلاحظها، ويحاول فهم الأشياء كما هي موجودة عليه بالفعل؛ حتى يكون قادراً على التعبير عن أنماط السلوك والعلاقات المتبادلة بينها بطريقة موضوعية.

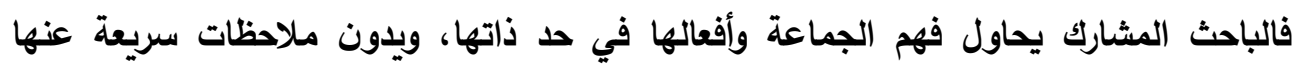

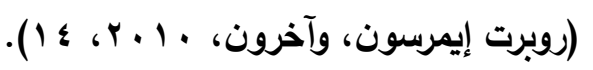

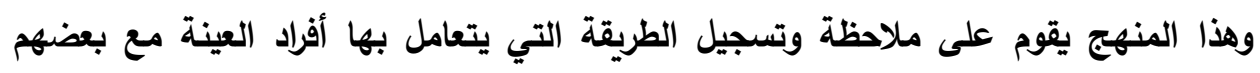
البعض (أعضاء مجالس الأمناء والآباء والمعلمين)؛ بدرجة عالية من الدئة الدقة، وملاحظتهم وهم يتصرفون بثكل طبيعي، وذلك من خلال معايشة الباحثة لأعضاء هذه المجالس، ومن خلال حضور بعض اجتماعاتهم. كما استخدمت الدراسة المنهج الوصفي الأي لا يتوقف عند حد وصف الظاهرة أو المشكلة بل يتعداها إلى تفسيرها والتعمق فيها وتحليلها ومقارنتها بغيرها من الظاهرات أو المشكلات المختلفة. فالمنهج الوصفي يستخلم لتحليل الواقع الكمي لإدارة مجالس الأمناء والآباء والمعلمين في تعزيز

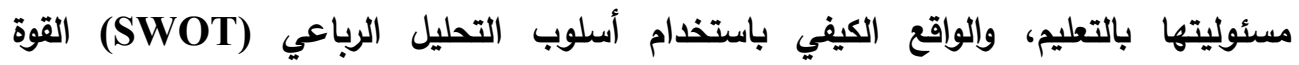
Threats والضعف Opportunities والتفرص Optrengths 
مجلة كلية التربية بالإسماعيلية - العدد الأربعون - يناير 1^ ب r بهاف الإفادة من هذا التحليل البيئي في وضع بدائل وآليات مقترحة لتطوير إدارة هذه المجالس في ضوء مدخل لامركزيـة الإدارة. أداة الدراسةة: - ماءة

استخدمت الدراسة بطاقة المقابلة وهي مقابلة متعمقة حيث إنها تتيح الحصول على معلومات متعقة من متخصصين في مجالهم وعلى علم بموضوع البحث. وتم تطبيقها على أفراد العينة المتمثلة في الددود البشرية لتعرف واقع تحقيق مبادئ لامركزية الإدارة بمجالس الأمناء والآباء والمعلمين بمحافظة المنوفية. مصطلحات الاراسة: باستقراء الأدبيات والأطر النظرية تتحدد المصطلحات الرئيسة للاراسة فيما يأتي: 1- مجالس الأمناء والآباء والمعلمين Boards of Trustees, Parents, and Teachers من الأعضاء هم آباء ومعلمين ومدير المدرسة وأحد الأخصائيين الاجتماعيين وبعض أفراد المجتمع المهتمين بالعملية التعليمية. وهدف هذه التظيمات توثيق العلاقة بين المدرسة والمجتمع المحلي في إطار من التعاون والمشاركة والتكامل وفي ظل نظام لامركزي. وذلك

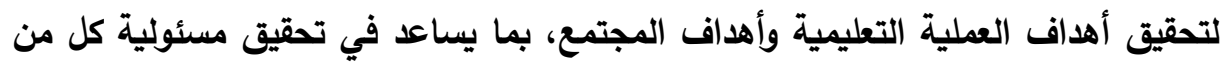
المؤسسة التعليمية والمجتمع. ץ- لامركزيـة الإدارة Decentralization: وتعرف إجرائياً بأنها قيام مجلس الأمناء بتسيير شئونه ذاتياً، في إطار من اللامركزية من خلال امتلاكه سلطة صياغة المهام وتحديد مسئوليات الأعضاء واتخاذ القرارات بناء على موارد المجلس وإحتياجاته إلى جانب احتياجات المجتمع، وتنفيذ هذه القرارات وتقويمها، مع تحمل أعضاء المجلس لمسئولية هذه

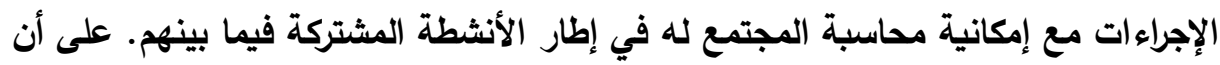
يتم ذلك من خلال التعاون بين أعضاء المجلس والتنسيق والاتصال بين هؤلاء الأعضاء والمشاركة في جميع الأعمال، وذلك في وجود إتاحة المعلومات مع توافر تفويض السلطات والصلاحيات من قائد المجلس إلى أعضائه. 
دراسة إثنوجرافية لمجالس الأمناء والآباء والمعلمين --------- د / هند سيد أحمد

خطوات الدراسـة:

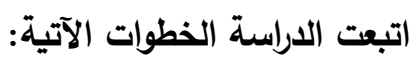

الخطوة الأولى: إعداد الإطار النظري للادراسة، ويشمل الآتي:

المحور الأول: مسئوليات مجالس الأمناء والآباء والمعلمين ومعوقات تحقيقها، ويتضمن ملامح

هذه المجالس، وعرض مسئولياتها، والمعوقات التي تحول دون تحقيق مسئولياتها.

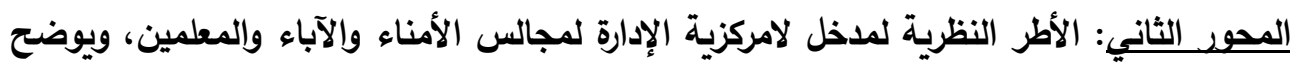

ماهية وأهداف وأهمية ومبادئ مدخل لامركزية الإدارة.

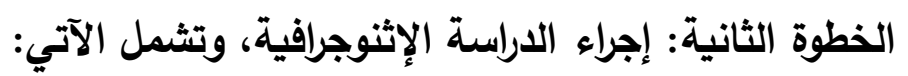

المحور الثالث: واقع تحقيق مبادئ لامركزية الإدارة بمجالس الأمناء والآباء والمعلمين (دراسة الآنة

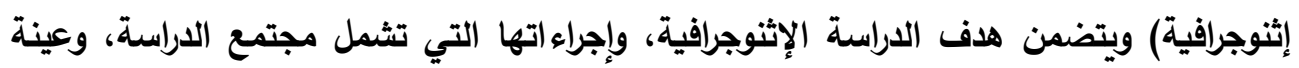
الدراسة، وتصميم أداة الدارة التي طبقت على العينة، وإجراءات تطبيق الاراسة الإثنوجرافية،

وصولاً إلى النتائج التي توضح واقع مجالس الأمناء والآباء والمعلمين.

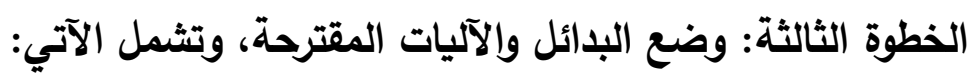

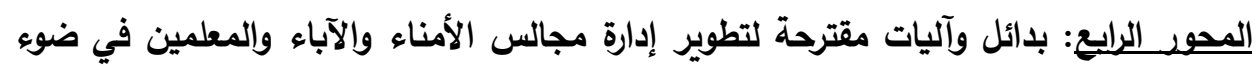

مدخل لامركزية الإدارة، من أجل تحقيق مسئولياتها بالتعليم.

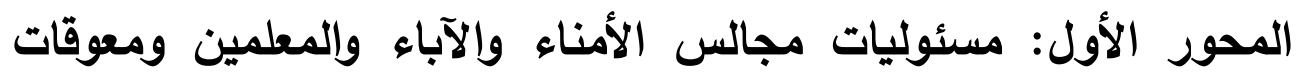

تحقيقها

ويتضمن ملامح مجالس الأمناء والآباء والمعلمين، وعرض مسئولياتها، والمعوقات التي تحول

دون تحقيق هذه المسئوليات.

أولاً: ملامح مجالس الأمناء والآباء والمعلمين هذه المبنولين

بالنسبة لهذه المجالس يمكن توضيح ماهيتها، وأهميتها، وأهدافها، وتثكيلها على الألحاء والأهو الآتي: أ- ماهية مجالس الأمناء والآباء والمعلمين

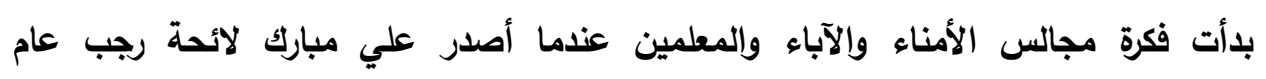

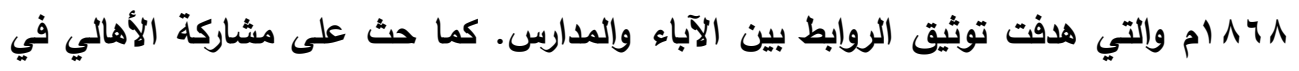

$$
\text { r.. }
$$




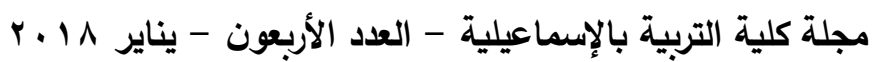

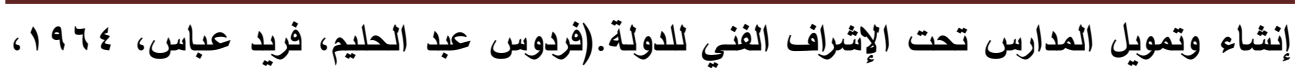
؛ ه)، وتم إنثاء أول مجلس للآباء والمعلمين في مدرسة النقراشي الثانوية النموذجية عام

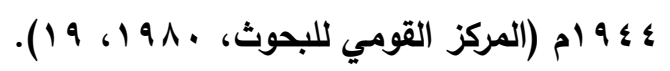

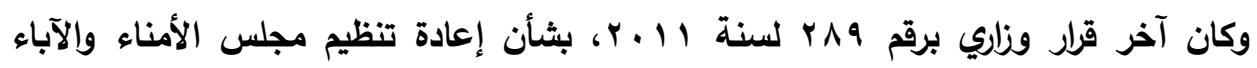
والمعلمين(وزير التربية والتعليم، 11 (ب)، حيث تضمن إنشاء مجلس للأمناء والآباء والمعلمين في كل مدرسة من مختلف مستويات المراحل التعليمية، يضم ممثلين للآباء والمعلمين وأعضاء من أفراد المجتمع المدني المهتمين بالعملية التعليمية. كما تضمن تثكيل مجلس للأمناء والآباء

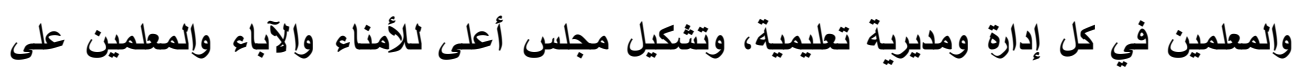
مستوى الجمهوريـة. إن مجلس الأمناء والآباء والمعلمين هو صيغة تنظيمية تربوية وإدارية، وهو تنظيم يعمل في اتجاه توثيق العلاقة بين المدرسة ومجتمع التلاميذ لصالح العملية التربوية، ولصاءلح كل من

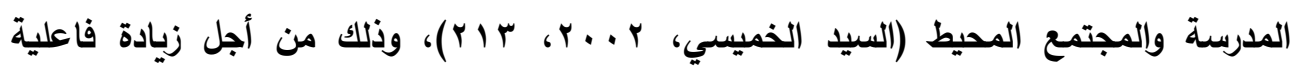

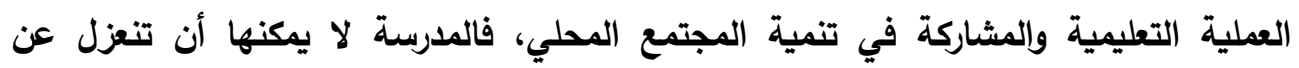
المجتمع الذي تتواجد به، وإنما تتفاعل معه من خلال مجالس الأمناء والآباء والمعلمين التي تسعى لتحقيق أهداف المدرسة وتساهم في تحقيق الأهداف العامة للمجتمع. وهذه المجالس تعتبر من الأنساق الاجتماعية الفرعية التي تساعد الإدارة المدرسية في تطوير العملية التربوية. ولذا فإن مجالس الآباء لها مدخلات ومخرجات، وتغذية عكسية، ومدخلاتها: الإدارة المدرسية ذات الخبرة المتميزة، والأخصائيون الاجتماعيون ذوو المهارات العالية، وكذلك ملكاء الآباء الذين لايهم الإدراك الكافي لمسئوليات المجلس، وأساليب التصرف بميزانية المجلس - كل ذلك سوف يؤدي إلى مخرجات تقاس بحساب العائد والتغذية المرتدة لزيادة وتدعيم العملية

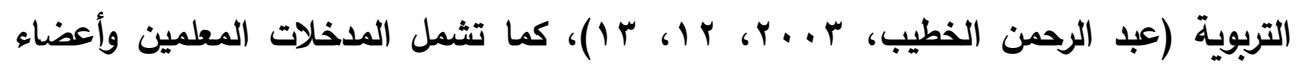
آخرين سيأتي ذكرهم في التثكيل، هؤلاء الأعضاء توجد بينهم علاقات وتفاعلات تسعى لتحقيق أهداف هذا التنظيم. ومن خلال هذه العلاقات يتم تبادل المعلومات والأفكار والآراء، ويحكم هذه العلاقات والأفعال التي يقوم بها هؤلاء الأعضاء قيم ومعايير وقواعد وضوابط محددة، وتتوقف قوة هذه العلاقات ومدى تحقيق الأهداف على شخصية وطبيعة هؤلاء الأفراد، كما أن أهداف هذاء التظيم هي في وفي وفي 
دراسة إثنوجرافية لمجالس الأمناء والآباء والمعلمين --------- د / هند سيد أحمد

حد ذاتها منبثقة من الأهداف العامة للمجتمع الذي تتواجد فيه المؤسسة التعليمية؛ ولذلك فإن هذه العلاقات والأفعال والتبادلات تمتد لتشمل علاقة هذا التنظيم (مجلس الأمناء) بتنظيمات المجتمع الأخرى لتتشارك وتتعاون وتتكامل مع بعضها البعض لتحقيق الأهداف العامة للمجتمع. فضلاً عن ذلك فإن الآباء يشاركون في مناقشة قرارات برامج المدرسة، والأشياء التي تدرس في الصف. كما أن تفاعل الطلاب مع آبائهم يساعد في معرفة التوقعات التعليمية لما بعد المدرسة الثانوية (Wells; et al., 2011, 1-32)، وتقترح بعض البلاد تعيين أشخاص من ذوي

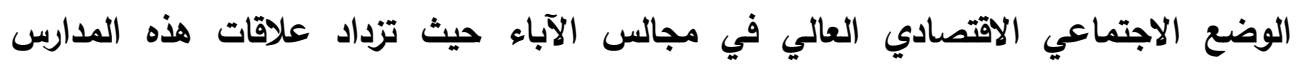
بالمجتمع، كما أن وجود الآباء في هذه المجالس يساعد على توسيع شبكاتهم الاجتماعية وتفعيل

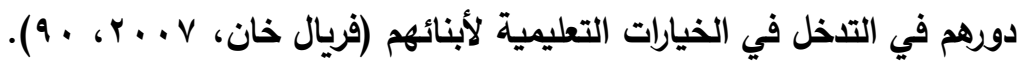
وهنا يتضح الأساس الأي تقوم عليه مجالس الأمناء والآباء والمعلمين فهي تقوم على مثاركة كل أعضائها في العملية التعليمية، بالإضافة إلى أن تفاعل الآباء في المجالس يؤدي إلى مزيل

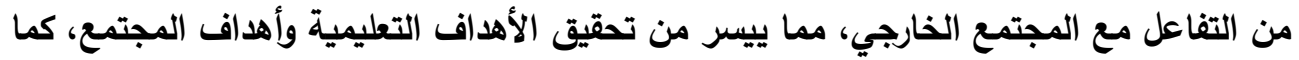
يوفر فوائد أخرى مثل زيادة تفهم كل من الآباء والمعلمين للتتلاميذ وزيادة تعرف اهتماماتهم ومن ثم يتم توجيههم التوجيه الأنسب للمرحلة التعليمية التالية. وفعاليات مجالس الآباء تتمثل في زيادة الدعم، حيث إن اللامركزية التي يتمتع بها مجلس الأمناء هي التي تسمح بوصول هذا الدعم من المجتمع الخارجي إلى مجلس الأمناء، ويتوقف

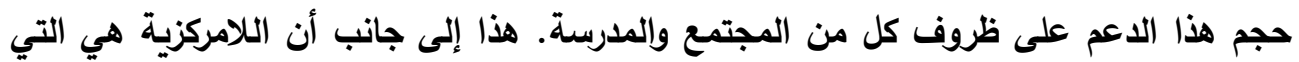
تسمح بتيسير الإجراءات المطلوبة لإتمام الأنشطة المختلفة. ومن هنا فإن مجالس الأمناء والآباء وإلمعلمين تعرف إجرائياً كما ورد بمصطاء الإسطات الإداسة. ب- أهمية مجالس الأمناء والآباء والمعلمين: يمكن تناول أهمية هذه المجالس من خلال أربعة أبعاد وهي: توطيا العلاقة بين المدرسة

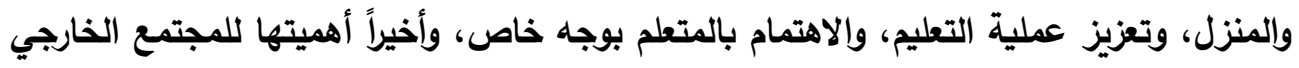
وأفراده والتي تعبر على نحو كبير عن مسئوليتها تجاه المجتمع. وهذا ما تعرضه الاراسة استناداً

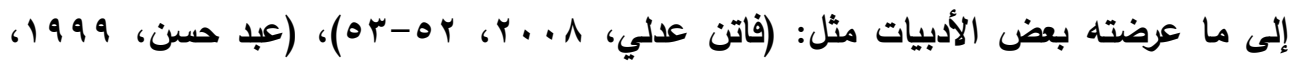

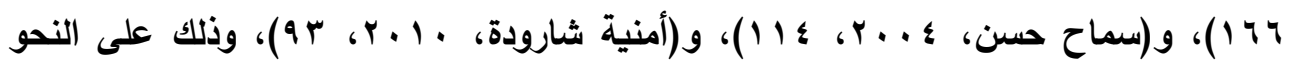
الآتي: 


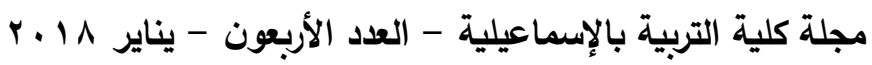
فبالنسبة إلى أهمية محالس الأمناء والآباء والمعلمين لتوطيد العلاقة بين المدرسة والمنزل وزيادة مستويات الثقة فيما بينهم؛ فتتضح في القضاء على تعارض وجهات النظر التربوية بين المدرسة والبيت، وتوفير الاعم المتبادل بين الآباء والمربين، فالمربون يدعمون الآباء بتقديم بضض البرامج التعليمية التي تستجيب لاهتمامات الآباء واحتياجاتهم، بينما يدعم الآباء المربين من خلال تطوع الآباء في المدارس وتنظيم الأنشطة وتخطيطها وتوفير الدعم المالي، واتخاذ القرارات التشاركية، كما تساعد هذه المجالس على إنشاء اتصال ثنائي، فلكل من الآباء والمربين معلومات حيوية يشاركون فيها معاً، مما ينشئ توقعات مشتركة بالنسبة للتلاميذ والمدرسة.

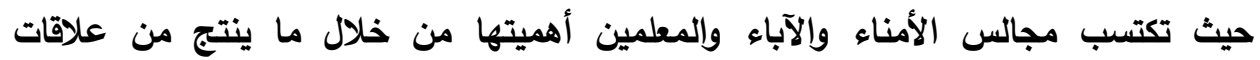
ومشاركة وتبادل للمعلومات، ودعم وإحداث توافق بين جميع الأطراف، مما يجعل أعضاء هذه المجالس يسيرون على نفس الطريق في توقعاتهم لمستقبل الطلاب. وهذا يزيد من مستوى الثقة فيما بينهم مما يحقق أهداف العملية التعليمية وبما يؤدي إلى تحقيق الصالح العام للمجتمع. وبالتالي تحقيق الفوائد المرجوة. أما أهمية مجالس الأمناء والآباء والمعلمين لتعزيز عملية التعليم فتتبين من خلال توفير البيئات التعلمية الفعالة في محيط المدرسة والبيت والبيئة المحيطة، ومناقشة القضايا والأمور المرتبطة بالعملية التعليمية/ التعلمية. والتخطيط للأنشطة التربوية الإيجابية. إلى جانب الإفادة من كافة الإمكانات الموجودة سواء على مستوى المدرسة أو على المستوى

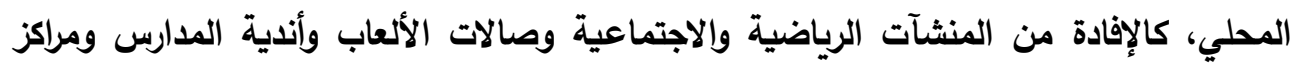
الشباب، والورش والمختبرات والمسارح والقاعات وغيرها. وتعد المشاركة الأبوية عاملاً مساعداً في إزالة المعوقات التي تعرقل تقدم العملية التعليمية التربوية من خلال طرح الأفكار وإبداء الآراء. والمساهمة في إعداد مخرجات تعليمية وتربوية سليمة قادرة على مواكبة المتطلبات الحياتية، وعندما تساهم مجالس الأمناء والآباء والمعلمين في ذلك فإنها تجذب الطلاب للمدرسة وتجعلهم يقبلون على التعليم وبالتالي تعمل على انخفاض معدل تسرب التلاميذ. وفيما يخص أهمية هذه المجالس للمتعلم على وجه التحديد، فتظهر من خلال تقديم أقصى قر مستطاع من العون للمتعلم لمساعدته على إحراز أفضل ما يستطيع تعلمه في جميع مجالات التعلم المختلفة. وتعزيز نتائج التعلم المدرسي، وتنظيم وقت المتعلم، وتقديم التوجيه والإرشاد 
دراسة إثنوجرافية لمجالس الأمناء والآباء والمعلمين --------- د / هند سيد أحمد

المناسب له. بالإضافة إلى دورها في التنشئة الاجتماعية للمتعلم من خلال تبادل الرأي بين المعلمين والآباء.

هذا إلى جانب الدور الديني من خلال المساهمة في تنظيم البرامج التثقيفية والأنشطة المدرسية التي تدعم القيم الدينية. واستثمار المناسبات الدينية لتقوية الوازع الديني لاى التلاميذ. وتوفير الكتب الاينية.

وبالنسبة إلى أهمية هذه المجالس للمجتمع الخارجي وأفراده فتتمثل في المساهمة في حملات التوعية والتثقيف على مستوى المجتمع المحلي والعالمي. من خلال ما تقوم به هذه المجالس من إجراء الاتصالات اللازمة مع المسئولين في أجهزة الإعلام المختلفة، لتعمل على تنمية الوعي مأهي التربوي عن طريق تنظيم الندوات والمؤتمرات وغيرها. فهي تساهم في زيادة الوعي بين الأفراد

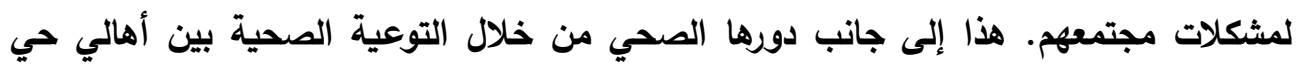
المدرسة. والتعاون مع وزارة الصحة في وضح الخطط للوقاية من التعرض للأمراض المعدية. فضلاً عن دورها في تكوين وتنمية العمل الجماعي(التعاون) حيث تمارس فيها الديمقراطية. وتساعد هذه المجالس على تحول المواطنين من مجرد متلقين لبرامج وسياسات التعليم، إلى شركاء فاعلين تسهم أصواتهم وممارساتهم في عمليات اتخاذ القرار. وهذا ما أكده (علي جلبي، مناه

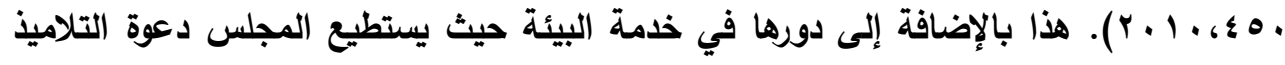
وأولياء أمورهم وشباب الحي إلى تحسين مستوى البيئة، وتحفيزهم على التطوع في مشروعات وبرامج تنمية مجتمعاتهم المحلية. فضلا عن تنظيم الرحلات والمعسكرات والزيارات. ونظراً لأهمية مجالس الأمناء والآباء والمعلمين لجميع أطراف العملية التعليمية، وللمجتمع ككل؛ فإن ذلك يتطلب تحقيق أهداف محددة، والتي تشتق من أهداف المجتمع الذي تتواجد فيه المؤسسة التعليمية. جـ - أهداف مجالس الأمناء والآباء والمعلمين: ويمكن تحديد أهداف مجالس الأمناء والآباء والمعلمين من خلال الاطلاع على الأدبيات

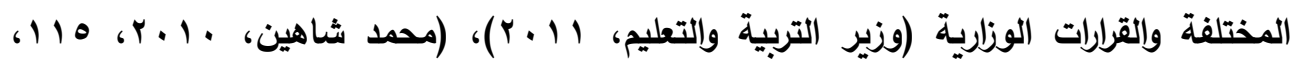

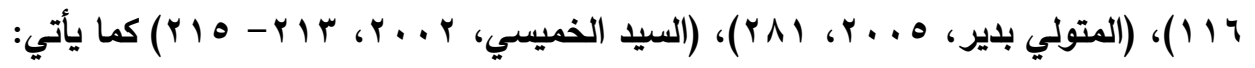
إن أول هذه الأهداف هو تعلم الايمقراطية وغرسها في نفوس أعضاء المجلس والعاملين بالمدرسة والطلاب عن طريق تطبيقها فعلياً. وهذا ما يتم عند تطبيق اللامركزية التي تعتبر هدفاً 


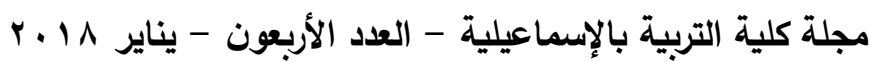

آخر لهذه المجالس والتي تتم هي الأخرى عن طريق توزيع السلطة على جميع الأعضاء وعدم تمركزها في شخص واحد. على أن يتم تحقيق اللامركزية في الإدارة وصنع القرار والمتابعة والتقويم.

ومن أهم أهداف هذه المجالس أيضاً: العمل على تحقيق التقارب بين المدرسة والمنزل بهدف تهيئة فرص التلاقي بين الآباء والمعلمين في جو ودي. وهذا ما يتم إيجاده من علاقات اجتماعية

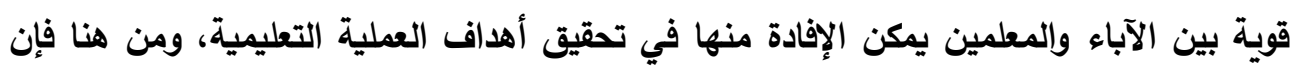
هذه المجالس تهاف إلى توثيق الصلات والتعاون المشترك بين الآباء والمعلمين وأعضاء المجتمع المدني في جو يسوده الاحترام المتبادل من أجل دعم العملية التعليمية ورعاية الطلاب. ويمكن أن يتحقق هذا الههف من خلال نشر الوعي التربوي والتعليمي وتبصير الآباء وأعضاء

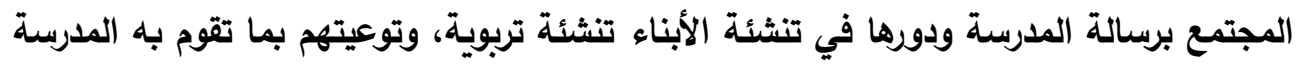
من أنثطة رياضية وثقافية واجتماعية وفنية ليتعاونوا مع المدرسة لتحقيق رسالتها لتعود الفائدة على الطلاب. وحتى يتم هذا التعاون بين الآباء والمعلمين وأفراد المجتمع والطلاب؛ من الضروري تحقيق أهداف أخرى مثل إكساب هؤلاء الأطراف المعلومات والمعارف والقيم الأخلاقية والاتجاهات السليمة التي تساعد على تعميق روح الانتماء للمجتمع والوطن. وتثجيع الجهود الذاتية والتطوعية لأعضاء المجتمع المدني لتوسيع قاعدة المشاركة المجتمعية والتعاون في دعم العملية التعليمية. وهذا يتم من خلال تعبئة جهود المجتمع المحلي من أجل توفير الرعاية المتكاملة للطلاب، وبصفة خاصة الفائقين والموهوبين وذوي الاحتياجات الخاصة لحل مشكلاتهم وللارتقاء بهم علمياً وثقافياً. هذا إلى جانب التنسيق مع الأجهزة المساعدة في المجتمع المحلي لاستثمار إمكاناتها في

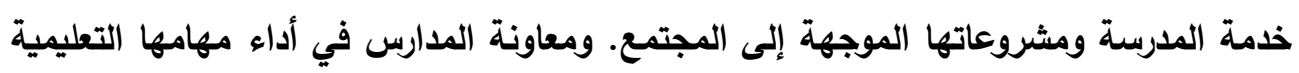

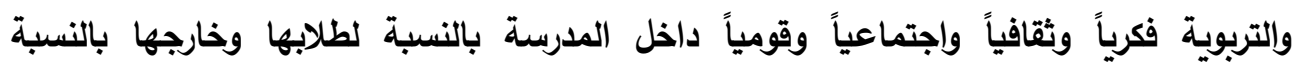

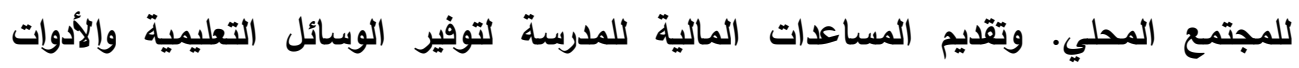
والخامات. فمن أهداف هذه المجالس تثجيع التبرعات والبحث عن مصادر تمويل غير تقليدية وإخال تكنولوجيا التعليم بالمدارس بهدف المساهمة في دعم العملية التعليمية. وهذا يهدف إلى ربط المدرسة بالبيئة المحيطة بها. 
فضلاً عن ذلك فإن مجالس الأمناء والآباء والمعلمين تهاف إلى الارتقاء بالعملية التعليمية من خلال التظلب على المشكلات والمعوقات التي قد تعترضها بالتعاون بين الأمناء والآباء والمعلمين. وذلك عن طريق دراسة المشكلات التي قد تعترض الطلاب سواء في البيت أو المدرسة. وإثعار التلاميذ بقدر من الاطمئنان النفسي والاهتمام بمشكلاتهم مما يساعد على مضاعفة جهودهم في التحصيل الدراسي. وتقديم المساعدات الفنية للمدرسة في مجال التعامل مع الطلاب والتغلب على التى هذه الصعوبات والمثكلات. واكتثاف وجذب الكفاءات الثخصية المختلفة من بين الآباء والأمهات للمشاركة في حل المشكلات. وإبداء الرأي في اختيار مدير المدرسة، أو ناظر المدرسة وفي تقويم أداء عمل كلا منهما عند التجديد لأي منهما.

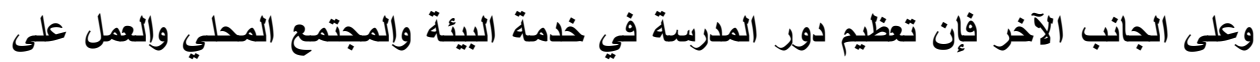
التغلب على مشاكلها وتحقيق طموحاتها. يمثل هدف مهم من أهداف مجالس الأمناء والآباء والمعلمين. وهذا يتم من خلال التعاون بين الأسرة والمدرسة لحل بعض مشكلات البيئة المحلية مثل المواصلات والنظافة والتغذية بما يجعل المدرسة مركز إثعاع يخدم البيئة ومتطلباتها. ومن هنا فإن تحقيق مجلس الأمناء والآباء والمعلمين لأهداف العملية التعليمية بل وأهداف المجتمع ككل؛ يتطلب وجود تشكيل محدد لهذه المجالس يضم عناصر من جميع الأطراف المهتمة بالعملية التعليمية. د - تثكيل مجالس الأمناء والآباء والمعلمين: تبين الدراسة تثكيل مجالس الأمناء والآباء والمعلمين على مستوى كل من المدرسة، والإدارة التعليمية، والمديرية التعليمية، ووزارة التربية والتعليم كما يأتي (وزير التربية والتعليم، 1 الـ ب): المستوى الأول: على مستوى المدرسة: تثكل الجمعية العمومية لأولياء الأمور على مستوى المدرسة من أولياء أمور كافة تلاميذ

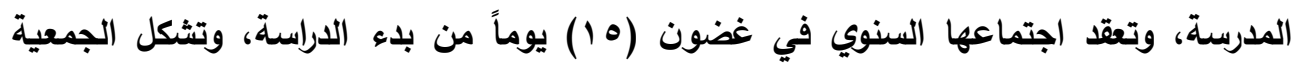
العمومية للمعلمين على مستوى المدرسة من جميع معلمي المدرسة، وتعقد اجتماعها السنوي في غضون 10 يوم من بدء الدراسة. يثكل مجلس الأمناء والآباء والمعلمين للمدرسة من (ب آ) عضواً على النحو الآتي: (0) أعضاء يمثلون أولياء أمور التلاميذ من غير المعلمين والعاملين بالمدرسة يتم انتخابهم عن طريق الجمعية العمومية لأولياء الأمور ، ( ) أعضاء من الثخصيات العامة المهتمة بالتعليم 


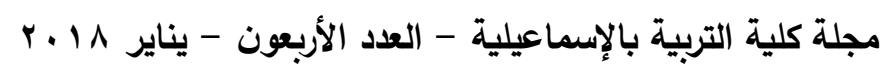

يختارهم المحافظ المختص، (T) من معلمي المدرسة ينتخبهم المعلمون في اجتماع الجمعية العمومية للمعلمين ممن ليس لهم أبناء بالمدرسة، بالإضافة إلى مدير المدرسة. ويتم انتخاب التماب

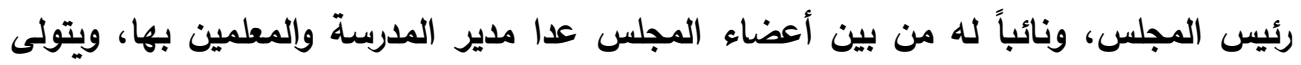

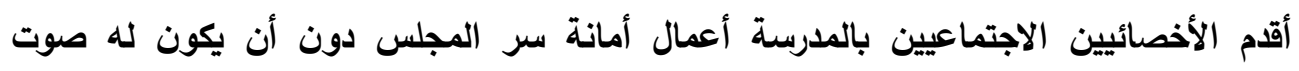

معدود.

ويعقد مجلس الأمناء والآباء والمعلمين للمدرسة جلسة واحدة على الأقل كل شهر، وكذلك كلما

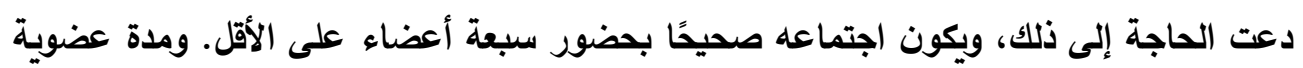

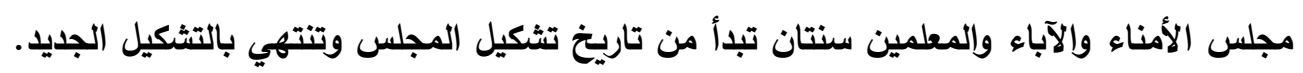
ويكون مدير المدرسة هو حلقة الاتصال بين المجلس وهيئة التدريس والعاملين والطلاب تلاب بالمدرسة، ويعتبر التوجيه المالي والإداري بالإدارات التعليمية مسئول عن متابعة الجوانب المالية

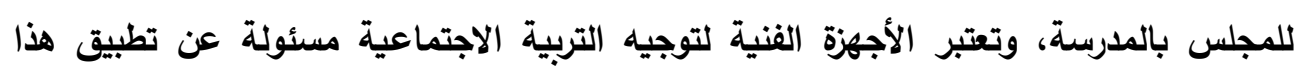
القرار والالتزام بأحكامه. المستوى الثاني: على مستوى الإدارة التعليمية: يثكل المجلس على مستوى الإدارة التعليمية من عدد(10 1 ) عضواً على النحو الآتي:

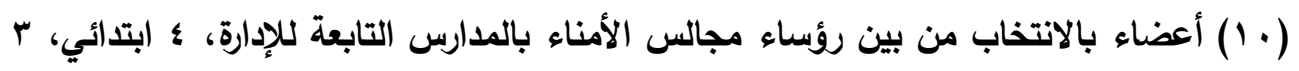
إعدادي، ب ثانوي منهم واحد فني)، (؛) أعضاء من الثخصيات العامة والمهتمين بالتعليم يختارهم المحافظ المختص، بالإضافة إلى مدير الإدارة التعليمية. ويتم انتخاب رئيس المجلس

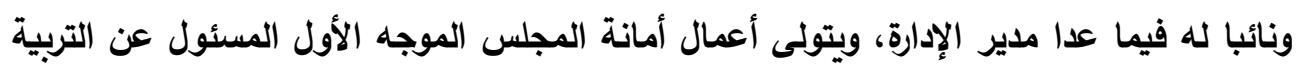
الاجتماعية بالإدارة.

المستوى الثالث: على مستوى المديرية التعليمية: يثكل المجلس على مستوى المديرية التعليمية من (0 1 ) عضواً بطريقة تثبه تشكيله في الإدارة التعليمية. المستوى الرابع: على مستوى ديوان عام الوزارة بالجمهورية:

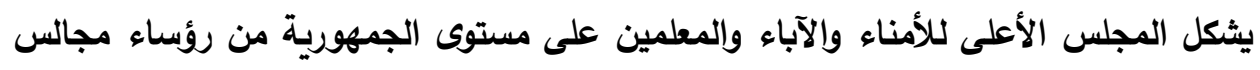
الأمناء بالمديريات التعليمية، و(ه) أعضاء من المهتمين بالعملية التعليمية والتربوية يختارهم وزير التربية والتعليم، ورئيس الإدارة المركزية للخدمات التربوية بالوزارة. ويتم انتخاب رئيس لائيس 
دراسة إثنوجرافية لمجالس الأمناء والآباء والمعلمين ---------_ / هند سيد أحمد

المجلس ونائب له فيما عدا رئيس الإدارة المركزية للخدمات التربوية، ويتولى مدير عام الإدارة العامة للتربية الاجتماعية بالوزارة أمانة سر المجلس. تعقد مجالس الأمناء مرة واحدة على الأقل شهرياً بالإدارة، ومرة واحدة على الأقل كل شهرين بالمديرية، ومرة واحدة على الأقل كل ثلاثة أشهر بالنسبة للمجلس الأعلى للأمناء.

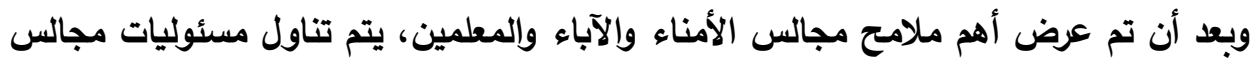
الأمناء والآباء والمعلمين وذلك على النحو الآتي: ثانياً: مسئوليات مجالس الأمناء والآباء والمعلمين إن مجالس الأمناء والآباء والمعلمين تعاون المدرسة وتيسر قيامها بأهم مسئولياتها وهي تعليم أبناء المجتمع؛ من خلال تربية الطلاب علمياً وثقافياً، ودينياً، وخلقياً، واجتماعياً، وسياسياً، لهاء وفنياً، وأدبياً، وذوقياً. كما تقوم بإكساب الطلاب القيم المختلفة والارتقاء بمهاراتهم، من خلال

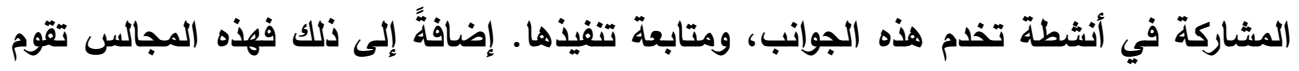
بالمشاركة في برامج تقويم سلوك الطلاب، فهي تعاون المدرسة في إرشاد الطلاب ورعايتهم نفسياً وتنمية قراتهم لمواجهة الظواهر السلبية التي يتعرضون لها (تلخين، إدمان، عنف، وغيرها...)، فقد يكونون محرومين من الرعاية الاجتماعية والنفسية على مستوى أسرهم، ويتم ذلك من خلال

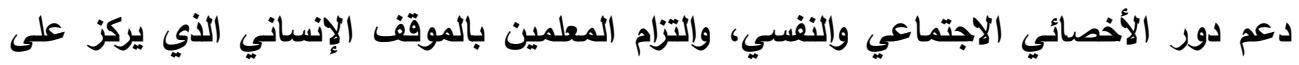
العلاقة الثخصية المتبادلة بين المعلمين والطلاب، إلى جانب تأصيل ثقافة السلام والتسامح. ومن مسئوليات هذه المجالس الحث والتعاون على حل المشكلات المجتمعية من خلال تشجيع

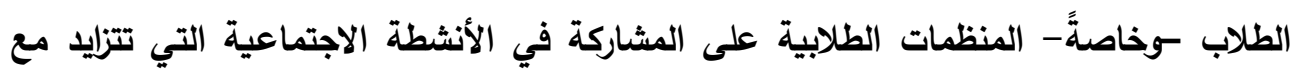
تبني مفهوم المسئولية الاجتماعية للمؤسسات التعليمية بما يبين البعد الإنساني لها واهتمامها لهابها بمشكلات المجتمع. كما تبين أن الطلاب يكونون منفتحين على العمل التطوعي، وأنه يمكن الجمع بين متابعة الدروس والالتزام الاجتماعي المتمثل في المشاركة في الأنثطة الاجتماعية. ومن هذه

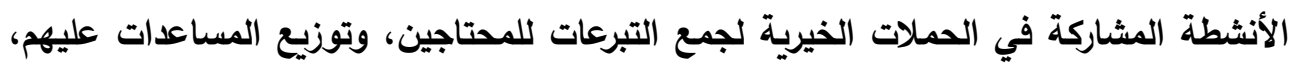
وزيارات دور الأيتام، أو المسنين، أو المعاقين، وغيرها، والمشاركة في تقديم دروس للمحتاجين، وأعمال الخدمة العامة (كالتظيف والتشجير والدهانات)، ويتم تنظيم هذه الأنثطة من خلال عقد اجتماعات مع منظمات المجتمع المدني خاصة المهتمة بالتعليم. وهذا ما أكده بعض الباحثين 
مجلة كلية التربية بالإسماعيلية - العدد الأربعون - يناير 1^ ب r

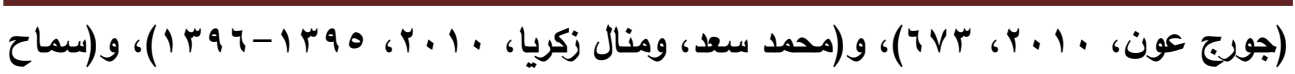

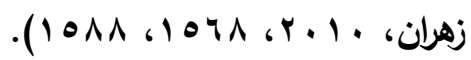

ومن جانب آخر فإن مجالس الأمناء والآباء والمعلمين عليها أن تنسق مع قطاع الأعمال. إما من خلال مشاركة بعض رجال الأعمال في عضوية هذه المجالس؛ وإما من خلال تكوين علاقات

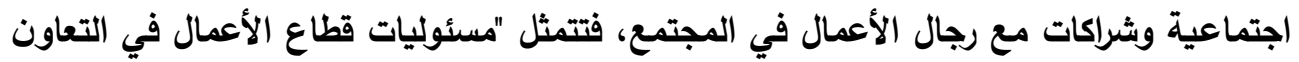
مع مؤسسات التعليم في المجتمع من خلال إتاحة الفرصة للطلبة والدارسين بها على التعليم

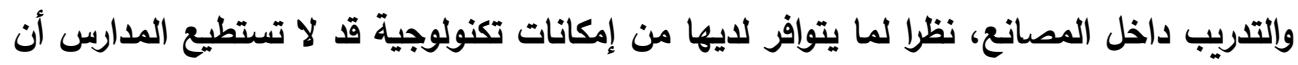

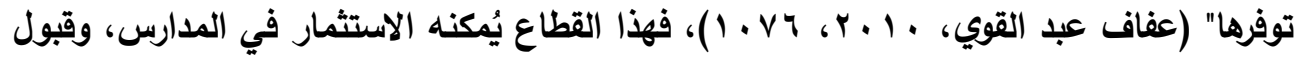
نسبة من الطلبة المتفوقين محدودي الاخل كمنح دراسية بشروط يتفق عليها (عبد الراضي

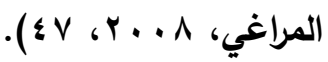

إن مجالس الأمناء والآباء والمعلمين أصبحت من الأهمية لكي يسود التعاون بين المدرسة

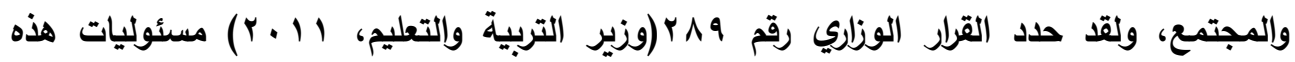
المجالس في مصر وهي: المساهمة الفعالة وعقد مناقشات مع إدارة المدرسة وغيرها من المشرفين على المدرسة، تتضمن تقديم الخبرة والرأي في مختلف المجالات التربوية والتعليمية حول أوضاع التعليم، والموازنات، والبيئة التعليمية للمدرسة بما تثمله من أمور تتعلق بالمناهج وطرق التدريس والطلاب والموظفين، ووضع خطة متكاملة لتحقيق أهداف تطوير المدرسة تصنة ومتابعة تنفيذها واتخاذ قرارات بشأنها، والمشاركة في تذليل الصعوبات والمشكلات الطلابية والتعليمية التي قد تواجهها، والعمل على توفير الرعاية اللازمة والبرامج والأنشطة التربوية للفئات الخاصة من الطلاب مثل الفائقين والموهوبين وذوي الاحتياجات الخاصة، وتوفير الرعاية الاقتصادية والاجتماعية للطلاب غير القادرين. كذلك حدد القرار الوزاري رقم (Y^9) نمط التعاون من خلال العمل على دعم العملية التعليمية وتطويرها وتحديثها بمصادر تمويل غير تقليدية عن طريق تثجيع الجهود الذاتية للأفراد القادرين ورجال المجتمع المدني، لمواجهة تنامي الطلب الاجتماعي على التعليم، والنهوض بمتطلبات الجودة وذلك من خلال البحث عن شراكات مع المحيط الخارجي، وهذا ما أكده (أحمد أوزي،

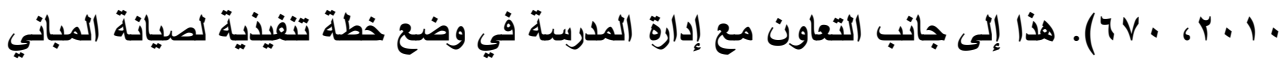

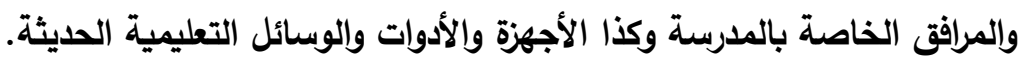


فضلاً عن ذلك فإن من مسئوليات هذه المجالس؛ تقدير وإنفاق أي مبلغ من أمواله لتحقيق الخطة التي قررها المجلس في حدود الموازنة. واعتماد الحساب الختامي للمدرسة وفق الخطة المقدمة. وإعداد التقرير السنوي الذي يعطي صورة مفصلة عن نشاطه وأعماله والذي يتضمن المشروعات والخدمات التي قام بها أو شارك فيها مقرونة بما أنفق عليها والصعوبات التي حالت فئل دون تنفيذ بعض ما ورد في خطته، ولا يجوز عرض التقرير السنوي على الجمعية العمومية إلا

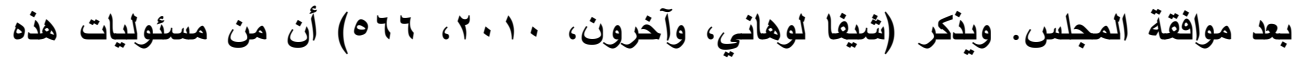
المجالس السيطرة على حسابات المدرسة، وفحص الإدارة المالية والأداء المدرسي بأكمله،

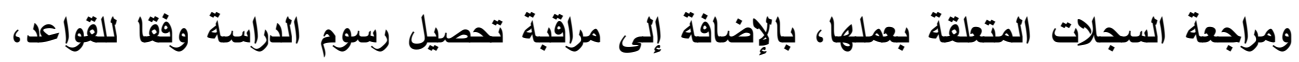
وتحديث ومراجعة المعلومات الخاصة بالأنشطة التعليمية للمدرسة. إلى جانب التعاون بين المدرسة والمؤسسات الأخرى كالجامعات ومراكز الثباب والجمعيات الأهلية والإعلام والثقافة لاستغلال ما يوجد بها من إمكانات تستثمر في دعم العملية التعليمية

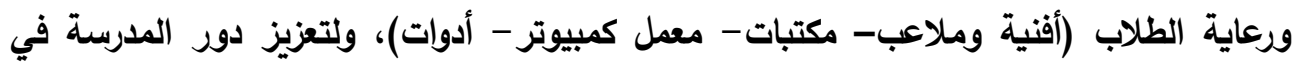
خدمة البيئة المحيطة والتعامل مع مشاكلها وطموحاتها مثل؛ توفير فرص تعليم وتدريب غير معلير رسمية، وفتح فصول محو الأمية وتقديم مجموعات تقوية، وتعليم المهارات الحياتية والمهارات

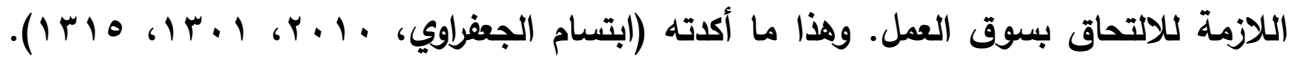
إلى جانب التوعية الاجتماعية بمشكلات المجتمع وقضاياه المختلفة، وزيادة فعالية النادي الصيفي. هذه كانت أهم مسئوليات مجالس الأمناء والآباء والمعلمين، والتي تقوم بها بالتعاون مع تنظيمات المجتمع الأخرى. ومما تقدم يتضح أن هذه المسئوليات تدور بصورة مباثرة حول

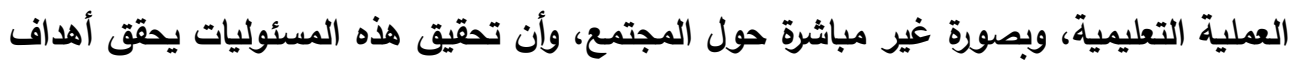
العملية التعليمية بصفة خاصة، وأهداف المجتمع العامة. ولكن يتبين من الأدبيات والدراسات السابقة أن هناك ما يعوق هذه المجالس عن تحقيق مسئولياتها. ثالثا: معوقات تحقيق مجالس الأمناء والآباء والمعلمين لمسئولياتها: ويمكن تصنيفها إلى معوقات مجتمعية، ومعوقات بشرية (تتعلق بأولياء الأمور)، ومعوقات 


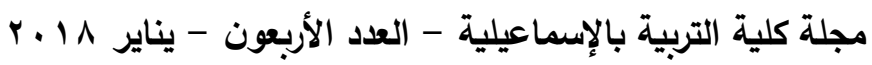

أ- بالنسبة للمعوقات المجتمعية فهي ترجع للمجتمع المحلي والمشاركة المجتمعية، وتتمثل في ضعف الوعي بقيمة مجالس الأمناء والآباء والمعلمين وأهميتها في العملية التعليمية، ووجود فجوة عميقة بين المدرسة ومجتمعها المحلي، حيث لا تهتم المدرسة بمشكلات مجتمعها المحلي، ولا تتعاون هيئات المجتمع ومؤسساته بالثكل الكافي مع مجالس الأمناء والآباء والمعلمين بالمدارس، وهذا قد يرجع إلى غياب ثقافة المسئولية الاجتماعية.

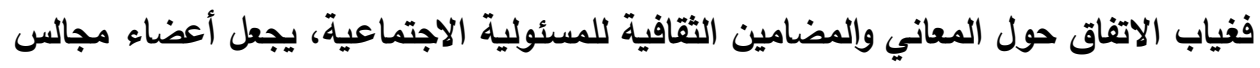
الأمناء أو أفراد المجتمع لا يدركون حقوقهم وواجباتهم والقيم والمبادئ التي تحفز القيام بهذه

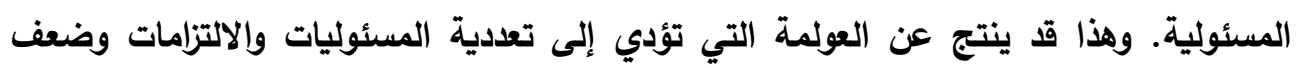
تحديدها وتداخلها. كما تؤدي إلى تعددية القيم والمعايير التي تتؤثر على درجة الثقة في هذه

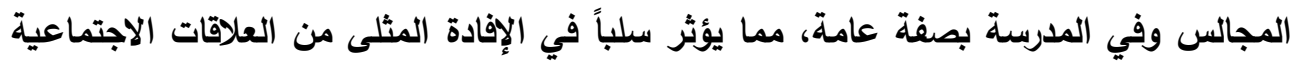

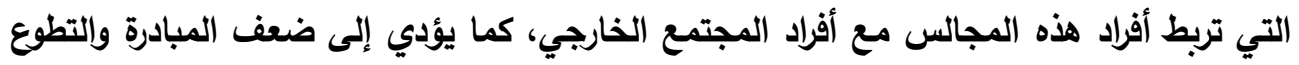
والتعاون بين أفراد المجتمع وأعضاء هذه المجالس. وفي إطار غياب ثقافة المسئولية الاجتماعية، فقد يكون من أسبابها أيضاً الإعلام الأي يلعب دوراً أساسياً في تشويه الحقائق المتعلقة بالمجتمع ومؤسساته ومنها المدرسة، كما يؤثر على قيم ومعايير ومعتقدات الفرد والتي تؤثر بالضرورة على اهتماماتهم مما يؤثر سلباً على قيامهم

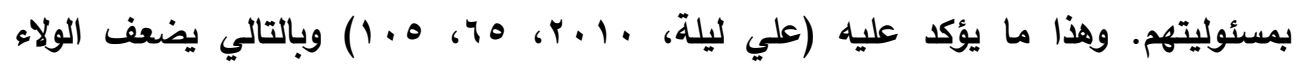
والانتماء للمتمع، وتقل الثقة في تنظيماته مثل المدرسة ومجالسها، كما تقل ثقة هذه التنظيمات في بعضهم البعض، وبالتالي يعزف أعضاؤها عن المشاركة في الحياة العامة، وبالتالي قصور في تحقيق مسئوليات هذه المجالس. فضلاً عن ذلك فالمعوقات المجتمعية تشمل ما يسود المجتمع من تنوع في المؤسسات التعليمية من تعليم أجنبي وآخر حكومي الأمر الذي يجعل النظام التعليمي لا يعمل وفق أسلوب لهن

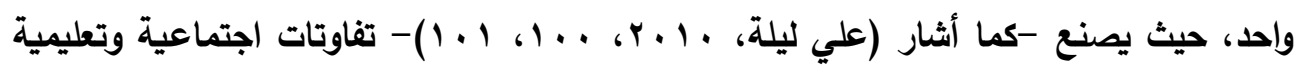
بين التلاميذ، يتلوها تفاوت في القدرة على الحصول على نصيب من الفرص الاجتماعية يترتب عليها تفاوتات في مستويات الانتماء للمجتمع، وتخلي المعلم عن مسئوليته في تعليم التلاميذ من خلال آلية الدروس الخصوصية، وبالتالي تقل مشاركة التلاميذ والمعلمين في ما تقوم به مجالس الأمناء والآباء والمعلمين من أنشطة تحقق مسئولياتها. 
دراسة إثنوجرافية لمجالس الأمناء والآباء والمعلمين --------- د / هند سيد أحمد

ومن هنا فإن هذه المعوقات المتمثلة في غياب ثقافة المسئولية الاجتماعية، والعولمة، والإعلام، وتنوع المؤسسات التعليمية وأنظمة التعليم؛ من شأنها أن تقلل من اهتمام أعضاء

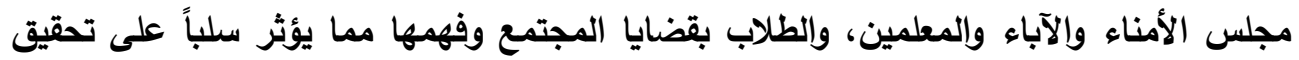
مسئولياتها، فعندما يتبنى هؤلاء الأعضاء بعض القيم أو الثقافة ذات الطبيعة الجامدة؛ فإنها تصرفهم عن فهم احتياجات المجتمع، وتجعل من الصعب عليهم التنبؤ بالتحديات والمشاكل الاجتماعية. وتمتد المعوقات المجتمعية لتشمل الضغوط الاقتصادية التي تضعف من قدرة أعضاء هذه المجالس وأفراد المجتمع على المشاركة الاجتماعية. ب- بالنسبة للمعوقات البشرية: فمنها ما يرجع إلى أولياء الأمور؛ وتتمثل في ندرة المعلومات المتوافرة عن المدرسة ومثكلاتها لاى الآباء مما لا يسمح لهم بالمشاركة النثطة الإيجابية في الحياة المدرسية. وإنخفاض المستوى التعليمي والثقافي والاقتصادي والاجتماعي لبعض الأسر، وبالتالي تلني لإني مستوى الوعي التربوي لايهم وانخفاض إدراكهم لأبعاد هذا التظيم ومسئولياته وأهميته (سماح

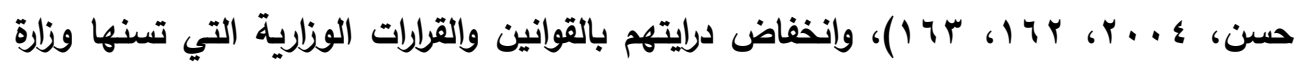
التربية والتعليم والمديريات والإدارات التعليمية والخاصة بمشاركة أولياء الأمور في متابعة وتطوير

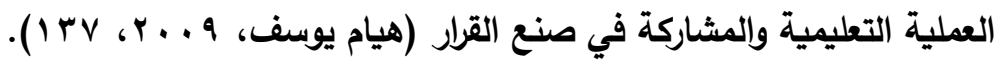
كما أن ضعف اهتمام بعض الآباء بقضايا مجتمعهم؛ لا يجعهم يحاولون القيام بجذب من

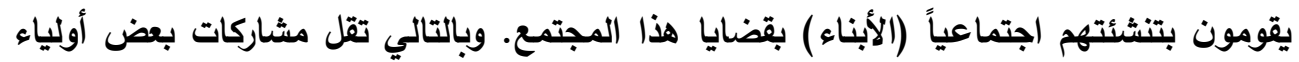
الأمور وبعض الطلاب في ما تقوم به مجالس الأمناء من أنثطة اجتماعية. إن ما قد يعوق التمام بعض أعضاء مجالس الأمناء والآباء والمعلمين بقضايا مجتمعهم ومشكلاته؛ سعى بعض الأعضاء لتحقيق مصالحهم الخاصة على حساب المصالح الاجتماعية العامة. وضعف العلاقات الإنسانية الطيبة فيما بين الأعضاء أو بينهم وبين الإدارة؛ أو بينهم وبين تنظيمات المجتمع الأخرى، وقصور الاتصالات المباشرة بينهم. هذا إلى جانب نقص الخبرة

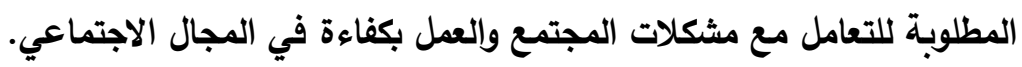
ج- وفيما يتعلق بالمعوقات الإدارية:

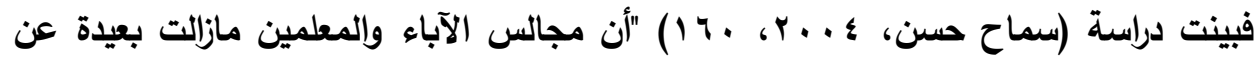
الصورة التي يجب أن تكون عليها، وأنها تعاني قصوراً شديداً سواء في أهدافها أو في تنظيماتها 


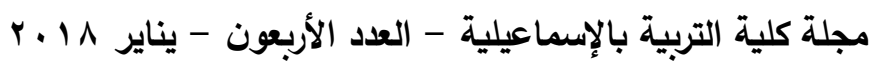
أو في أدوارها أو في الطريقة التي تدار بها"، فأداء هذه المجالس يتصف بالثكلية، وواقعها بالقصور، وتنظيماتها تفتقر للمصداقية، وبالتالي تفقد قيمتها. وهذا ما يظهر من خلال ما أشارت

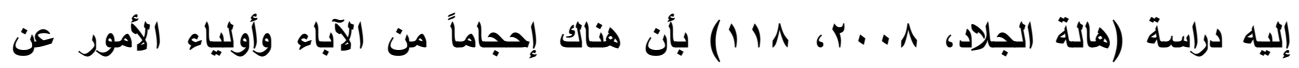

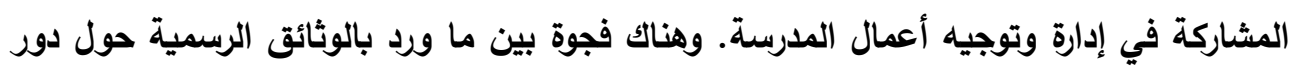
هذه المجالس وبين ممارساتها الفعلية نتيجة لما عانته تنظيماتها من قصور في نوعية فئه المشتركين وضعف حماسهر.

وهناك من المعوقات الإدارية ما يحول دون جذب اهتمام أعضاء هذه المجالس نحو قضايا

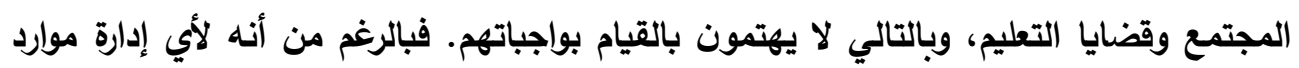

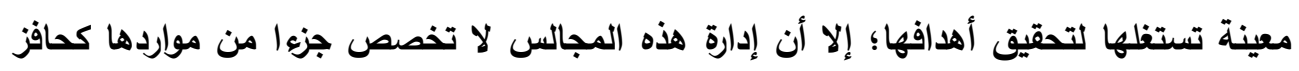

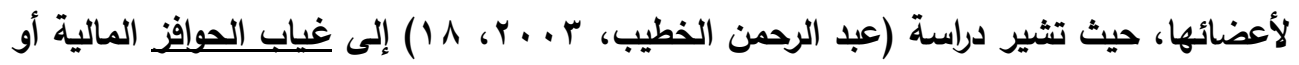

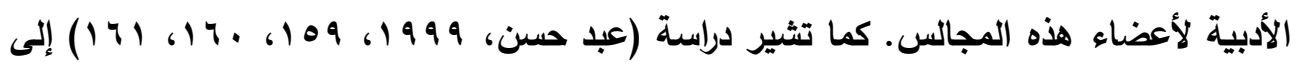

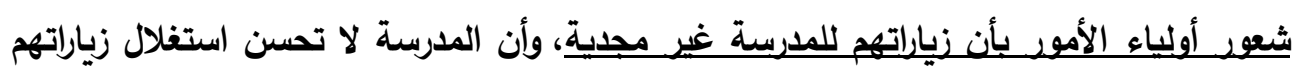
إليها، وأنها لا تطرح قضايا مهمة للمناقثة معهم. وتؤكد ذلك دراسة (وداد على الرحمن، وشهيرة

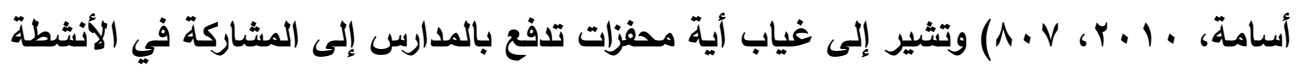

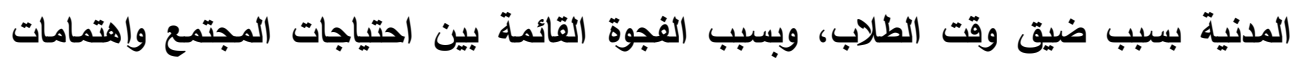
الطلاب.

كما أن الضغوط المهنية والإدارية لأعضاء مجالس الأمناء والآباء والمعلمين؛ والتي تتمثل في وجود أعمال أخرى مضافة إليهم غير كونهم أعضاء في هذه المجالس مثل: العمل المهني

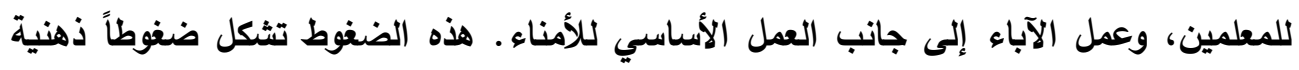

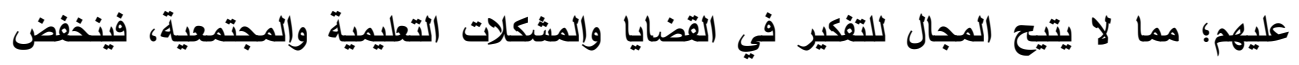
التزامهم بالمسئولية، هذا بالإضافة إلى أن الأعضاء لا يجدون الوقت الكافي لممارسة مسئولياتهم. فضلاً عن أنه من الأمور التي تضعف اهتمام أعضاء مجالس الأمناء بالمواقف المحيطة بهم في المجتمع وقضايا التعليم؛ فلسفة التعليم في مصر التي تقوم على المركزية والتي جعلت الناس التهاء يعتمدون على الحكومة في كل شيء يتعلق بالتعليم خاصةً التمويل، مما أدى إلى غياب التخطيط فيط 
دراسة إثنوجرافية لمجالس الأمناء والآباء والمعلمين --------- د / هند سيد أحمد

وروح المبادرة والسلبية، وافتقاد آليات التنظيم والإدارة للجهود الثعبية، وضعف إحساس السلطات المحلية بمسئولياتها عن التعليم وتمويله. وفي إطار المعوقات التي تضعف من اهتمام أعضاء مجالس الأمناء والآباء والمعلمين بالقضايا التعليمية والمجتمعية؛ سيادة قيم اجتماعية سلبية بين الأعضاء مثل الانعزلية والعزوف عن العمل العام أو العمل الجماعي، وغياب الروح التعاوني. إلى جانب العلاقات الاجتماعية التي

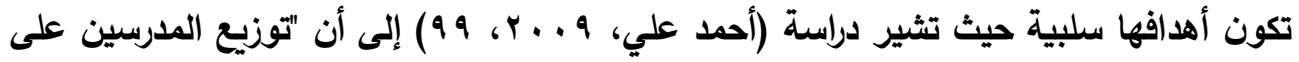

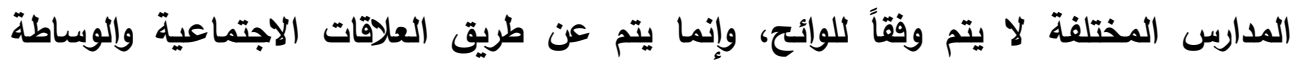
والمحسوبية، وبعيداً عن الاحتياجات الفعلية للعمل"، وهذا قد ينتج من ضعف اهتمام أعضاء مجالس الأمناء بالحاجات الفعلية للمجتمع. هذا بالإضافة إلى اهتزاء مكانة التعليم نتيجة لتخلي الدولة عن دورها في تعيين الخريجين،

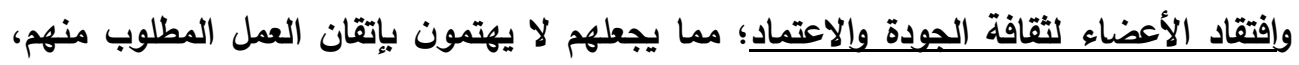
وبالتالي يجعل أفراد المجتمع يفقدون الثقة في التعليم، وبالتالي لا يتوافر لايهم الاهتمام لاعم التعليم وتحقيق مسئوليتهم تجاهه. وهناك من المعوقات الإدارية ما يعوق فهم أعضاء مجالس الأمناء للمدرسة وللمجتمع ولقضاياهم، وبالتالي تعوق تحقيق مسئولياتهم؛ حيث إن كفاءة هذه المجالس والتفويض الواسع الممنوح لها لا يسير بثكل منتظم. وقد يرجع ذلك إلى غياب فلسفة المشاركة المجتمية والعمل التطوعي، وندرة اطلاع أعضاء هذه المجالس على تجارب مجالس الآباء في الاول الأجنبية

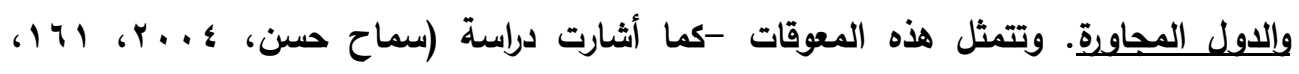

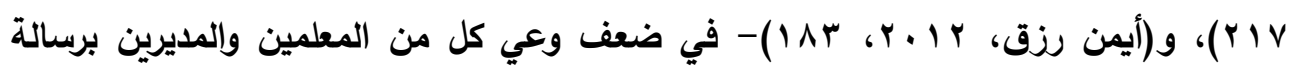

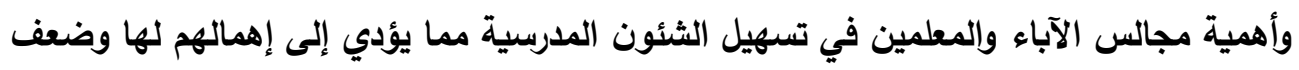
اهتمامهح بها، وضعف وضوح العلاقات والاختصاصات والمسئوليات بين ديوان عام الوزارة والمديريات والإدارات التعليمية.

هذا إلى جانب مقاومة الأعضاء لتحمل المسئولية بسبب قصور الفهم الناتج عن نقص البيانات والمعلومات والمعرفة، أي قصور الثفافية والعلانية التي تعين على التغيير والتطوير التير واتخاذ القرار. والتي تساعد الأعضاء على أداء مهامهم، وهذا ما أكلته دراسة (نجدة سليمان،

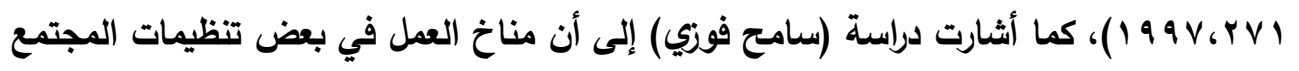




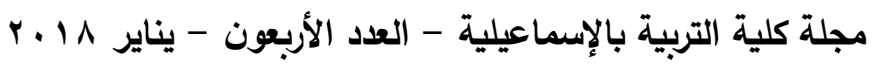

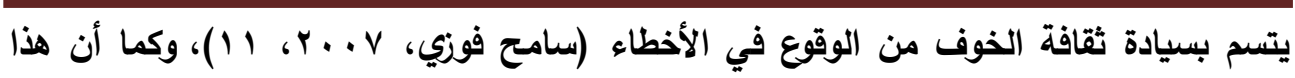
ينتج من ضعف الثقة؛ فإنه أيضاً يؤثر في روح الثقة بين الأعضاء وبعضهم البعض، وبين المجلس والأطراف المعنية بالتعليم. إلى جانب ذلك فإن قلة توافر المعلومات؛ يقلل من قدرة المجلس على تحديد احتياجات المدرسة والمجتمع؛ كما يؤدي بدوره إلى سوء توزيع السلطات والمسئوليات، وتداخل الأعمال والاختصاصات مما يعوق تحقيق مسئوليات المجلس. ومن المعوقات غياب الثقافة التظظيمية الإيجابية المشتركة. حيث تشير دراسة (هيلين مراد،

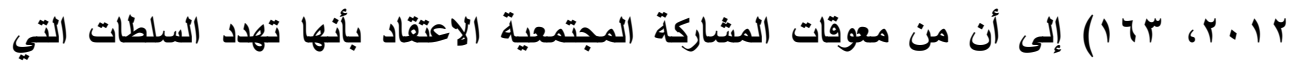

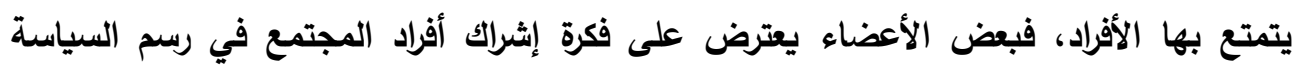
المدرسية اعتقاداً أن ذلك سلباً لبعض اختصاصاتهم وسلطاتهم، كما أن بعضهم يفضل عزل البهل

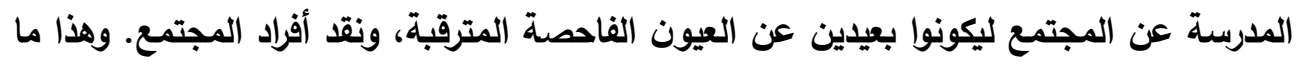

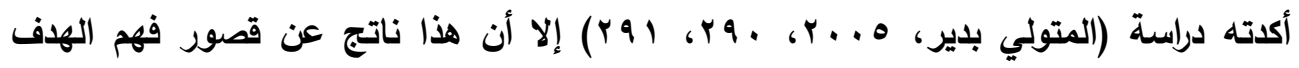
الحقيقي من عمليات المشاركة وإنففاض الدافعية للمشاركة المجتمعية، كما أنه ناتج عن سوء الفهم وضعف الوعي بأهمية أدوار باقي أفراد المجتمع. سواء بالنقد الذي يساعد على التحسين

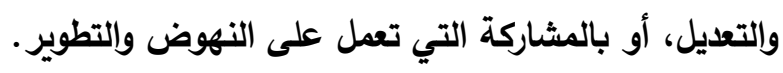
وهذه الثقافة التظظيمية السلبية تشجع الجهود الفردية، ولا تفسع المجال للجهود الجماعية.

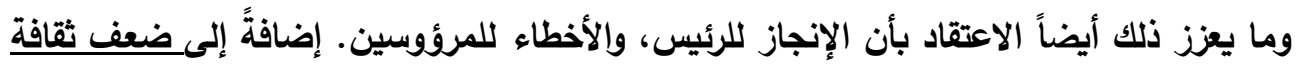

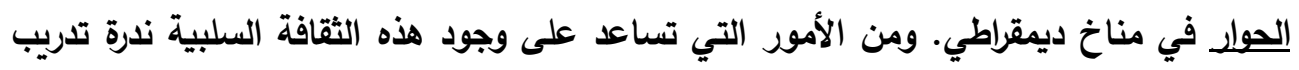

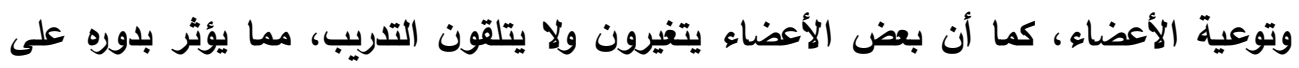

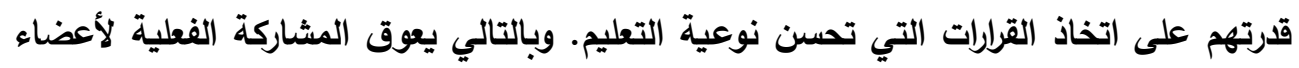
هذه المجالس عند قيامهم بتنفيذ أدوارهم وتقويمها. وهناك معوقات إدارية تحول دون مشاركة أعضاء مجالس الأمناء وقيامهم بمسئولياتهم وتتمثل في ضعف الإمكانات المادية والبشرية. فبالنسبة للمعوقات المادية فتتضمن نقص الدعم وتوفير مصادر وموارد للصرف والإنفاق على أنشطة المجالس. حيث إحجام أصحاب الأموال عن المشاركة. بالإضافة إلى الدروس الخصوصية التي تستقطع جزءً كبيراً من ميزانية الأسرة مما فيأ

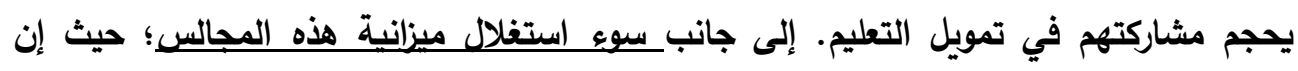
الإنفاق من حصيلة المجلس يتم دون تخطيط مسبق أو برامج متفق عليها، فضلاً عن أن كثيراً 
دراسة إثنوجرافية لمجالس الأمناء والآباء والمعلمين ---------_ / هند سيد أحمد

من المدارس تلجأ إلى الإنفاق من إيرادات المجالس على أعمال ومشروعات قـ تم تخصيص

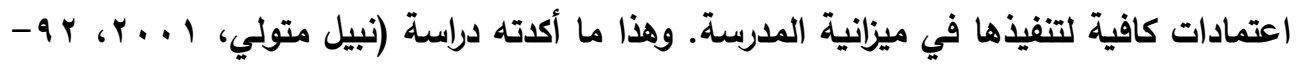

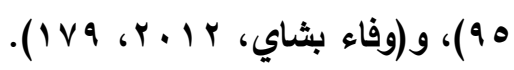

وتمتد المعوقات المادية لتشمل قدم مباني المدرسة ونقصها في بعض المناطق وهذا يؤثر سلباً

على بعض الأنشطة التي يمكن أن تخدم بها المدرسة المجتمع. وهنا يظهر معوق آخر أشارت

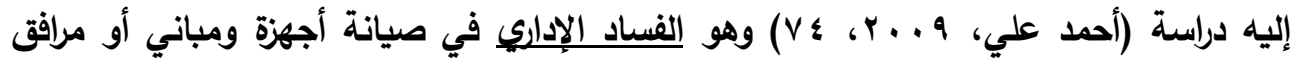
بعض المدارس سواء على الورق فقط أو بصورة غير مُرضية. مما يعوق المشاركة الفعالة وتحقيق الغرض منها. وعندما تحاول هذه المجالس القيام بمشروعات أو أنشطة أو إنشاء بناء داخل المدرسة يزيد من مواردها؛ فإنه غالباً ما يواجهها الروتين وجمود مناخ العمل نتيجة كثرة

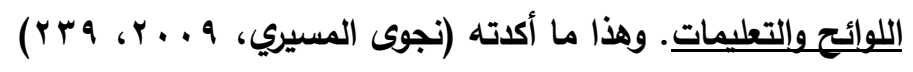

وهنا تظهر المعوقات الإدارية التي تتمثل في ضعف الأساليب الإدارية التي يمارسها أعضاء مجالس الأمناء الآباء والمعلمين والتي تعوق المشاركة في تنفيذ الأنثطة المتفق عليها. وتتمثل في قصور التنسيق والتكامل فيما بين أعضاء المجلس، وفيما بين المجلس وباقي تنظيمات المجتمع. وضعف نظام المتابعة والرقابة والإثراف على أعمال المجلس ومدى تنفيذ القرارات التي يتخذها. كما أن أسلوب الإدارة يكتم بمفهوم الرقابة والضبط والتفتشيش والعمل تحت ضغط، أكثر اعثي من اهتمامه بمفهوم التوحيه والمشاركة في المسئولية، بالإضافة إلى ضعف المرونية ومقاومة التغيير، وضعف التقويم المستمر لنتائج العمل، ووجود قصور وضعف واضح في قنوات الاتصال بين المستويات الإدارية، كذلك بين المدرسة والمجتمع، وبين المدرسة والأسرة، ووجود أسباب عديدة تعوق التعاون بين المدرسة والأسرة منها ضعف تنظيم المدرسة لأوجه التعاون، وشكلية

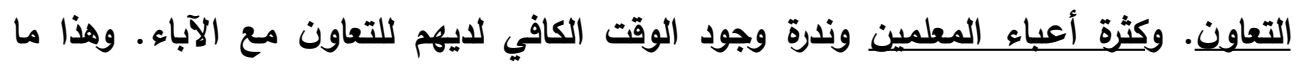

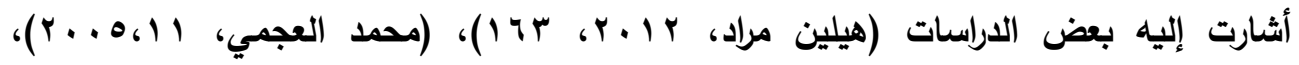

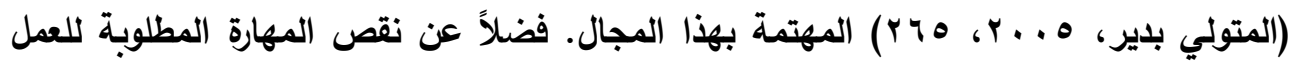
الجماعي، مما يعرقل المشاركة في رفع كفاءة وفعالية المدرسة. وبالرغم من أن مجالس الأمناء والآباء والمعلمين تعتمد في عملها بشكل أساسي على عقد الاجتماعات؛ إلا أن هذه الاجتماعات ينتابها مجموعة من المعوقات التي تؤثر على فعاليتها مما يعوق تحقيق مسئولية المجالس. فهناك من هذه المعوقات ما يحول دون جذب اهتمام أعضاء 


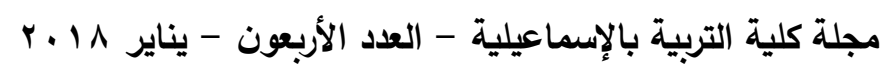

مجلس الأمناء ومنهم أولياء الأمور لحضور الاجتماعات. فتنخفض استجابة أولياء الأمور للمدرسة، ويعزفون عن حضور الاجتماعات. ومن هذه المعوقات -كما أشارت دراسة (عبد حسن،

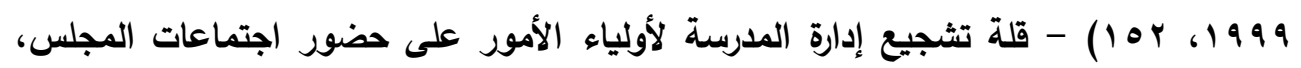

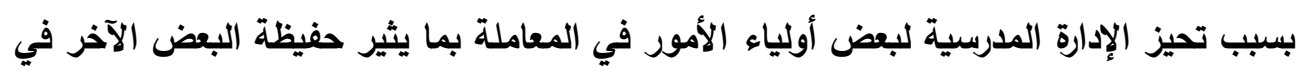

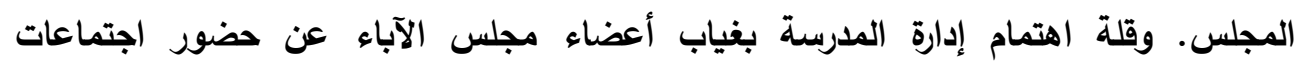
المجلس، بالإضافة إلى التبرعات المالية التي تطلبها المدرسة منهم، والتقصير في وصول دعوة إعلاء

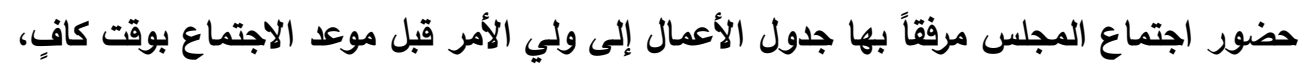

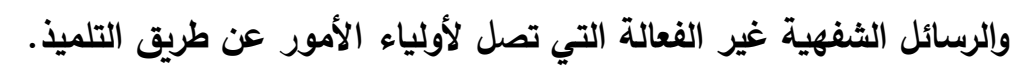
فضلاً عن سوء التخطيط الجيد لأعمال انعقاد الاجتماعات. والذي يعوق لهاء فهم الأعضاء لهاء للقضايا

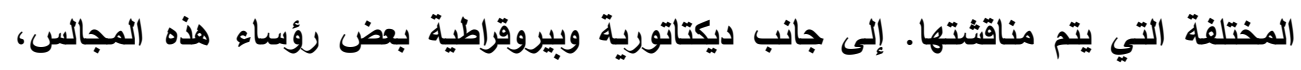
لأنهم يرون في المشاركة انتقاصاً من شأنهم وقدراتهم وسلباً لاختصاصاتهم، ومن ثم فإنهم

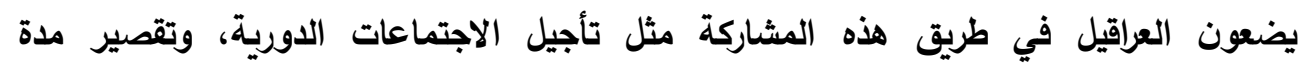

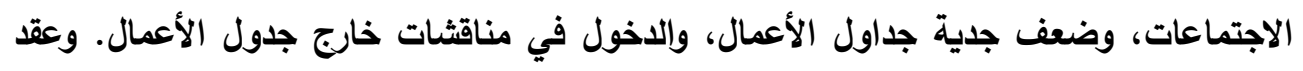
الاجتماعات خلال الوقت المحدد للعمل الحكومي مما لا يتيح للموظفين من أولياء الأمور إمكانية

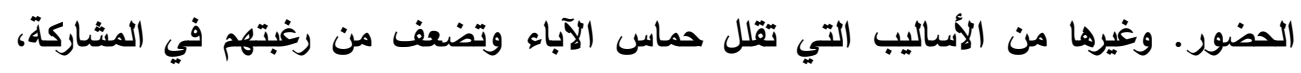

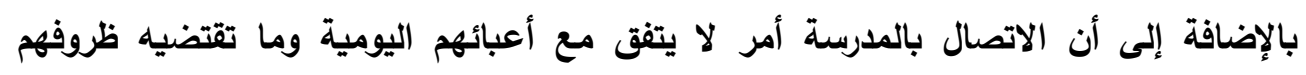

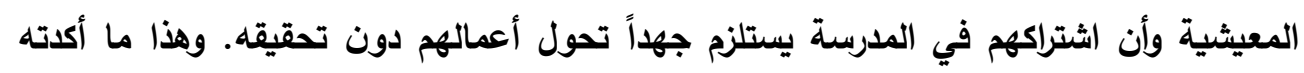

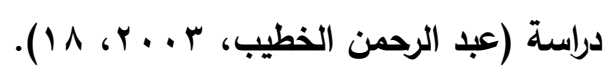

إن مساهمات أعضاء مجالس الآباء في القرارات التعليمية مساهمات جزئية فقط؛ فأعضاء المجلس ذوو النفوذ يميلون إلى توجيه القرارات التي يتخذها المجل، وأيضا يترك اتخاذ القرارات للقليلين من الأعضاء الذين يحضرون، كما أن الاقتراحات التي يقدمها بعض الأعضاء قد لا تجد

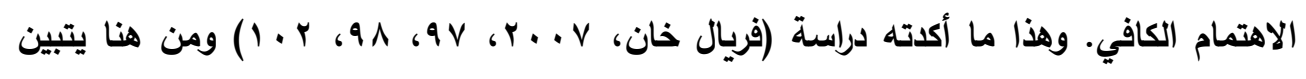
استحواذ بعض أعضاء مجلس الأمناء على اتخاذ القرالت عن البعض الآخر مما يعوق المشاركة العادلة بين جميع الأعضاء. وهنا تظهر المركزية الإدارية التي تظهر في الهيكل التنظيمي للإدارة وصنع القرار، وفي مركزية

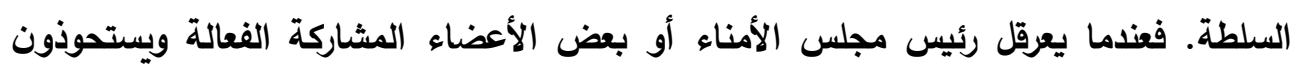


دراسة إثنوجرافية لمجالس الأمناء والآباء والمعلمين --------- د / هند سيد أحمد

على اتخاذ القرارات؛ فإن ذلك يكون -كما أثار (ستوارت باركر، V . . Y، ؛ )- في ضوء اعتقاد مؤداه أن هناك إجابة صحيحة واحدة في التعليم، وهذه الإجابة يعرفها فقط المدراء والمسئولون، الأمر الذي أدى إلى قمع التنوع في الآراء والاجتهادات وطرح البدائل وادله هذا بالإضافة إلى افتقار عملية اتخاذ القرار إلى المشاركة والديمقراطية، وفقدان التوازن بين السلطة والمسئولية، وافتقاد القدرة على القيادة. وتأجيل البت في الكثير من الأمور وتعطيل العمل أو تأجيله لحين موافقة الجهات المسئولة، كما أثرت التعقيدات المالية على إمكانية تزويد المدرسة بالأجهزة والأدوات ومن ثم على حسن سير العمل ومستوى الأداء بالمدرسة، فالواقع يثير إلى المركزية دون إدراك حقيقي لاحتياجات وظروف المناطق المحلية، وتجاهل للحاجات

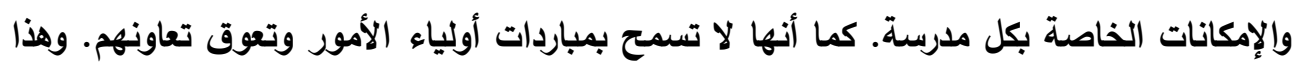

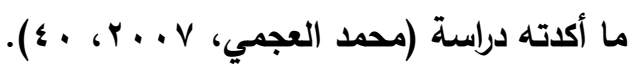
ويتضح مما سبق أن أغلب هذه المعوقات إدارية وتؤثر على تحقيق وتعزيز مسئولية مجالس الأمناء والآباء والمعلمين، وللتفلب على هذه المعوقات وتحقيق هذه المسئوليات على أكمل وجه الهـ فإن هذه التظيمات في حاجة إلى مدخل إداري يتناسب مع طبيعتها وطبيعة مسئوليتها ألا وهو مدخل لامركزية الإدارة، ويمكن تناول الأطر النظرية لهذا المدخل في الآتي: المحور الثاني: الأطر النظربة لمدخل لامركزية الإدارة لمجالس الأمناء والآباء والمعلمين يتناول هذا المحور ماهية مدخل لامركزية الإدارة، وأهدافه، وأهميته. إلى جانب مبادئ هذا المدخل. وذلك على النحو الآتي: أولاً: مدخل لامركزية الإدارة ماهيته، أهدافه، أهميته الهية تبين الدراسة ماهية مدخل لامركزية الإدارة، وأهدافه وأهميته على النحو الآتي: 1 - ماهية مدخل لامركزية الإدارة يمكن توضيح المقصود بمدخل لامركزية الإدارة من خلال ثلاثة جوانب. الأول: ينظر إليه من منظور فردي أي إدارة الفرد لذاته، والثاني: يركز في تعريف هذا المدخل على المنظور الجماعي أي إدارة جماعة معينة أو فريق معين لنفسه ذاتياً، والثالث: يتناول هذا المدخل على على أنه نظام،

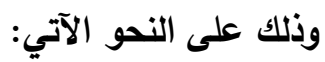




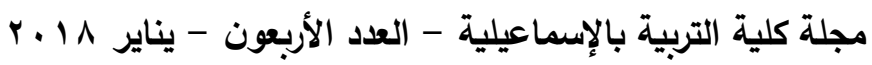

الجانب الأول: تعريف مدخل لامركزية الإدارة من منظور فردي: حيث يعرف (إبراهيم الايب،

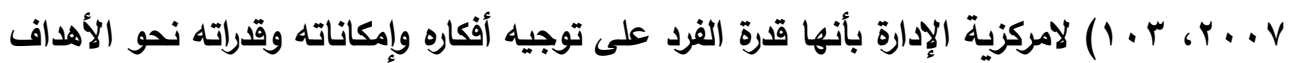

التي يصبو إلى تحقيقها، واستغلالها الاستغلال الأمثل.

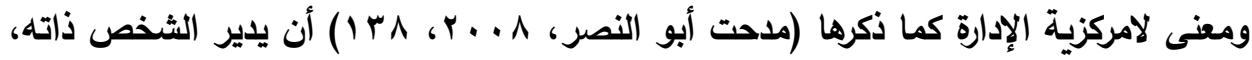

وأن يتحكم في نفسه، وفي مشاعره ويعدل اتجاهاته حتى تصبح مناسبة وإيجابية، وأن يعدل

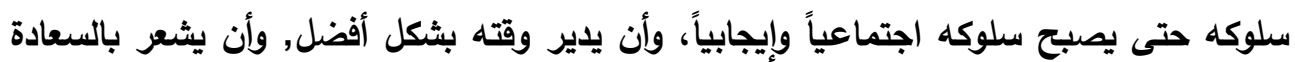
والتفاؤل في عمله وفي حياته، وأن يزيد من كفاءة وفعالية أدائه في العمل. وعليه فإن لامركزية الإدارة ثورة في الشئون الإنسانية تتطلب تغييرا كبيراً في الأفكار والأفعال.

الجانب الثاني لتعريف مدخل لامركزية الإدارة من المنظور الجماعي توضحه التعريفات الآتية. هو مدخل صُمم لجمع أعضاء المجتمع والمدرسة في نفس الإطار للتحدث حول تحقيق أفضل استثمار لهم في التعليم(Lane, 1992, 120)، فهو يقوم على تيسيير العمل في المدرسة بأسلوب ديمقراطي سليم، من خلال إتاحة الفرصة أمام جميع المعنيين بأمور التعليم (المعلمين والإداريين، والآباء، وأعضاء المجتمع المحلي، والطلاب) للمشاركة الفعالة في العمل المدرسي

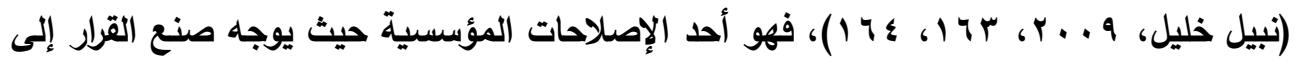
مستوى المدرسة. وبتضمين الآباء والمجتمع في المدارس يتوقع من مدخل لامركزية الإدارة أن

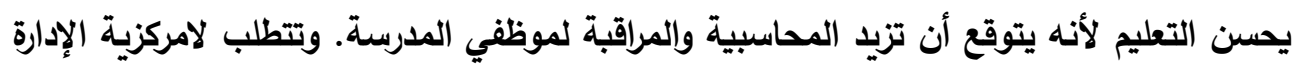
الحكم الذاتي للمدرسة، وإجراء تقييمات وتقديرات (Bando, 2010, 1)، وتتفق مع ذلك (رشيدة

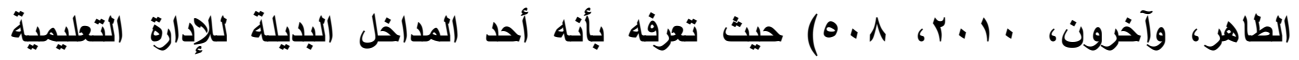
والمدرسية وهو أن يعه باتخاذ القرارات الإدارية للمستويات الدنيا في الهرم، وهي المستويات المجتمعية، مما يعزز مشاركة الأطراف المعنية في إدارة التعليم، كما أن نقل السلطة إلى مستوى المديه المدرسة وإستقلالها في صنع القرار يؤدي إلى كفاءة أكثر في تحديد واستخدام الموارد. ومن خلال مدخل لامركزية الإدارة يتم انتهاج العمل ضمن فريق وتشجيع التعاون والانفتاح بالمدرسة على المجتمع المحلي المحيط بها فدعم (لامركزية الإدارة) هو السبيل الأنسب للتغلب على المثكلات التعليمية وتفعيل دور المجتمع في إدارة المدرسة بثكل أفضل ومن ثم الحرية في الإدادي اتخاذ القرارات التي تمكنها من النهوض بأدوارها بكفاءة، وفي ظل مناخ قوامه الثفافية والمساءلة أمام الرأي العام المجتمعي، وتوسيع قاعدة المشاركة المجتمعية في صناعة القرارات التربوية على لماته 
دراسة إثنوجرافية لمجالس الأمناء والآباء والمعلمين --------- د / هند سيد أحمد

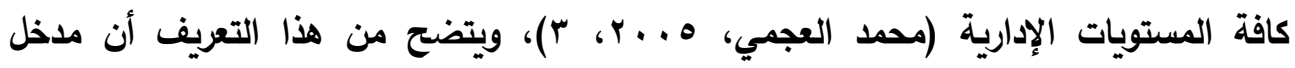

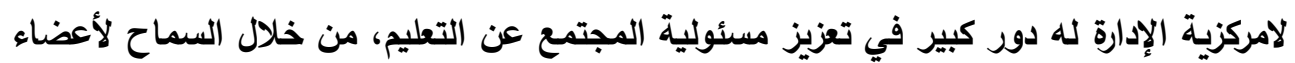

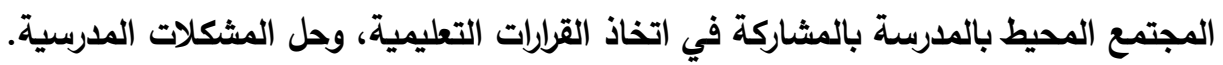
فلامركزية الإدارة هي "التحول الرسمي للهياكل التظظيمية، كصيغة من صيغ اللامركزية التي

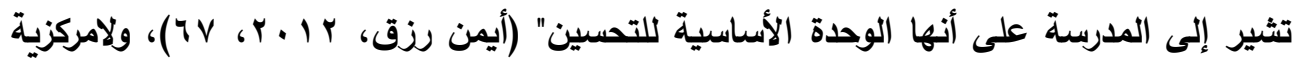
الإدارة تعد آلية تحقق جودة الأداء المدرسي ومنح المديرين مزيباً من السلطة والمسئوليات والحرية لتحقيق أهداف الإدارة من خلال مشاركة أفراد المجتمع المدرسي في عملية اتخاذ القرارات حيث إن للمجتمع المدرسي رؤية فريدة عن كافة جوانب الأداء المدرسي، ومعرفة وواقعية أكبر

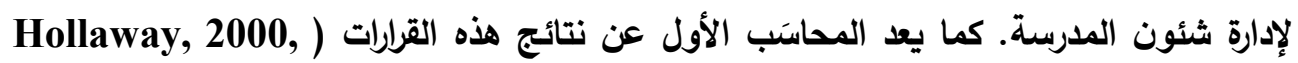
81, 82 (81)، فها المدخل يشمل "توزيع الأعباء والمسئوليات بين كافة العاملين، بجانب تبادل أدوار السلطة للمساهمة في حل مشكلات التلاميذ، وتحفيز العاملين بالمدرسة نحو ضرورة تحسين

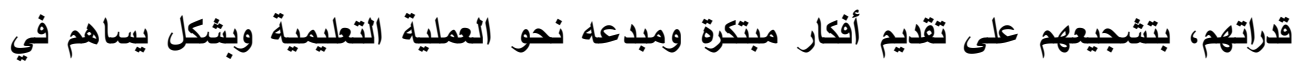

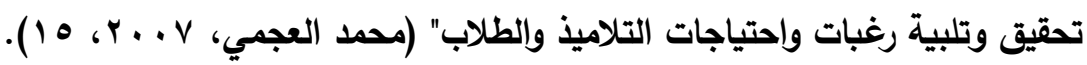
ويقوم هذا المدخل على الإحساس بالمجتمع والالتزام المشترك. و"يتضمن نمطاً من المجالس المكونة من أصحاب المصالح في المدرسة، وأحيانا تشارك هذه المجالس مدير المدرسة في فئي السلطة، فتساعده في صناعة القرارات وأحياناً أخرى يكون رأي هذه المجالس استثارياً فحسب".

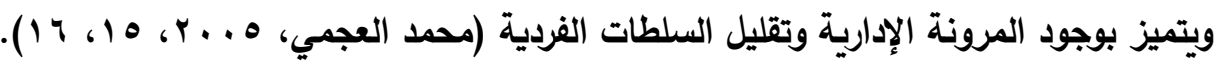
أما الجانب الثالث تناول من خلاله مجموعة من الباحثين مدخل لامركزية الإدارة على أنه نظام. ويمكن تناول وجهة النظر هذه في الآتي: لامركزية الإدارة ليست فقط إصلاح هيكلي أو إصلاح تعليمي ولكنها نظام تعليمي يهدف إلى الى التركيز على الإعداد والمساندة للمعلمين الذين يتم تدريبهم، وتركز على القيادات والمشرفين، والموارد المتاحة من كتب أو موارد تعليمية من خلال التنمية المهنية، وكذلك مشاركة الآباء

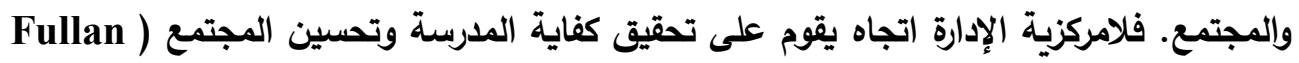

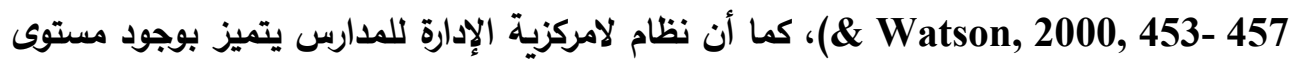
إداري لامركزي مستمد من مستوى سلطة المدرسة لاتخاذ القرارات المرتبطة بتخصيص الموارد 


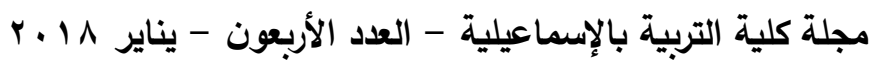

Cheng \& Chan, ) المختلفة التي تثمل: المعرفة، والتكنولوجيا، والأفراد والوقت، والتمويل .(2000, 205-232 ويتكون مدخل لامركزية الإدارة كنظام متكامل من مدخلات وعمليات ومخرجات كالآتي: المدخلات الإدارية: وتتمثل في الأفراد المشتركين في الإدارة وهم أعضاء مجالس الأمناء بالمدارس. وما يتسمون به من خصائص وسمات شخصية. وما يتوافر لديهم من ثقافة واستعداد. بالإضافة إلى القيم والمعتقدات والمعايير السائدة في البيئة، والتي تمثل رأس المال الاجتماعي. لئل هذا إلى جانب العلوم والمعارف والأساليب ومجالات تطبيق الإدارة. ويضيف (ماهر على) المعلومات المتصلة بالأوضاع والمواقف والأدوات والإمكانات والثفر والتقيود التي تتم في إطار

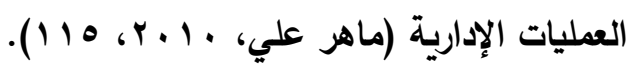
وبالنسبة للعمليات الإدارية: فهي تثمل أنشطة البحث والدراسة والتحليل، وعمليات التخطيط

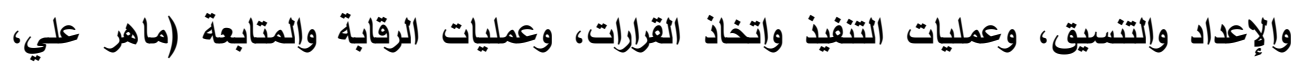

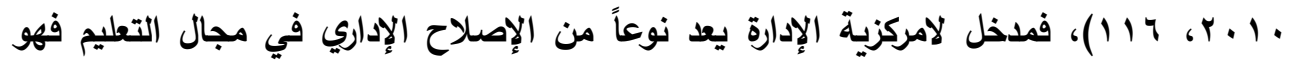
يسعى لتحقيق الأهداف العامة والخاصة التي تخطط المدرسة لها في ضوء عملية التحليل البيئي، وتقويمها في ضوء عملية التنفيذ. وهو عملية تتضمن مجموعة من الأنثطة والآليات المخططة

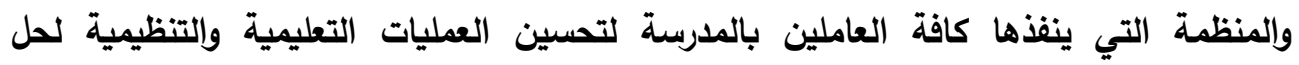

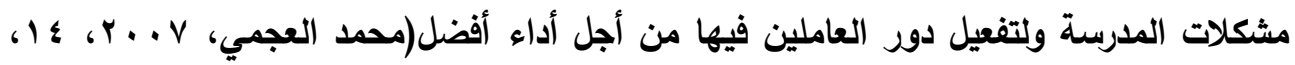
كما أنه عملية إعادة توزيع السلطة من خلال اللامركزية بإحداث المشاركة الجماعية من المعلمين والآباء وأفراد المجتمع المحلي في وضع سياسة المدرسة التعليمية، وصناعة القرارات التربوية على صعيد المدرسة. وصياغة وتسيير مهامها طبقا لظروف احتياجاتها، وبذلك يصبح أعضاء الإدارة المدرسية أكثر استقلالية وفعالية واستجابة ومسئولية في اتخاذ القرارات المتعقة بالمناهج الدراسية والتنمية المهنية وتوزيع الموارد البشرية والمادية في المدرسة، وأكثر استقلالية ومسئولية في توظيف الموارد المتاحة لحل المشكلات وتفعيل الأنشطة التربوية الفاعلة لتطوير المدرسة على المدى البعيد. كما يوفر هذا المدخل المناخ الإبداعي اللازم من أجل المشاركة

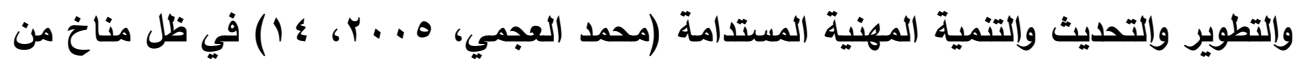


دراسة إثنوجرافية لمجالس الأمناء والآباء والمعلمين --------- د / هند سيد أحمد

الثقة والديمقراطية والثفافية والمساءلة التعليمية التي تمتد لتشمل مستوى التلاميذ الدراسي وأداء المعلم داخل المدرسة.

أما المخرجات الإدارية: فهي الاستراتيجيات والخطط، والقرارات على كافة المستويات، والإنجازات

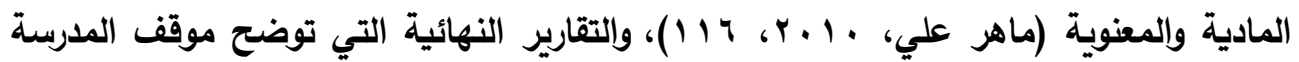
سواء بالإيجاب أو السلب. وبناء على ما سبق يتضح تعريف مدخل لامركزية الإدارة من اتجاهات مختلفة منها ما تناوله

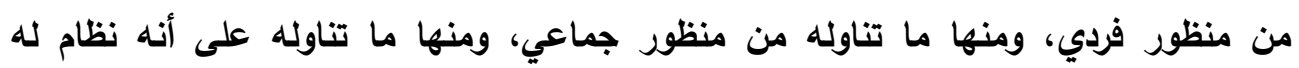
مدخلات وعمليات ومخرجات. وتأسيساً على ما سبق فإنه يمكن تعريف مدخل لامركزية الإدارة إجرائياً كما ورد بمصطات البحث.

كما يمكن تعريف هذا المدخل أيضاً بأنه مشاركة أعضاء المجلس وتعاونهم في جميع الوظائف الإدارية من تخطيط وتنظيم وتنسيق وتنفيذ وتوجيه ومتابعة ورقابة وتقويم، مع تثاركهم جميعاً

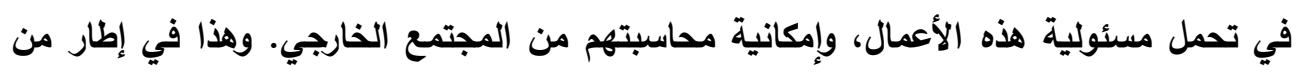
التعاون والتماسك والتكامل بين أعضاء المجلس في وجود مناخ من الثقة والعلاقات الاجتماعية الإيجابية بين الأعضاء. وكل ذلك لتحقيق أهداف المدرسة وأهداف المجتمع الذي وجلت فئ فيه لتحقيق أهدافه واحتياجاته وتلبية التزاماتها وواجباتها نحوه. ونظراً لأن محاولة تطبيق أي مدخل تتطلب معرفة الأهداف التي يهدف إليها، والتي استدعت

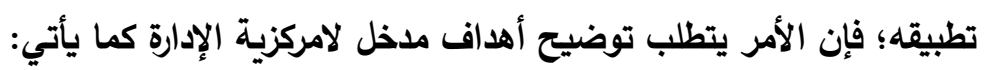
r - أهداف مدخل لامركزية الإدارة: تتمثل أهداف هذا المدخل في توفير القيادة الإدارية الواعية والمناسبة لأداء المهام، وتوفير

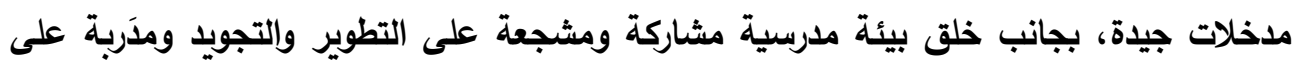
آلياته، والوقاية وحل المشكلات الناتجة مباشرة في ظل التوظيف الدقيق والذكي لتقنيات التعليم Smith \& ) والتكنولوجيا التعليمية ووجود قاعدة بيانات يمكن استخدامها بصورة دورية .(Clinton, 2001 كما يهدف مدخل لامركزية الإدارة بالمدارس إلى زيادة كفاءة الإدارة وذلك من خلال هيكل تظظيمي غير مركزي، بجانب تعزيز دعم الرأي العام والثقة في المدارس. فهو يهـف إلى دعم rr 


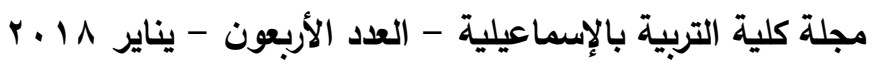

وتعزيز سلطات الآباء في مجلس إدارة المدرسة، وتحسين كفاءة استخدام الموارد في الخدمة التعليمية؛ ويهذف هذا المدخل إلى ضمان تطبيق مبادئ الجودة الشاملة على مستوى المدرسة. وتحسين جودة العملية التدريسية والمهارات الإدارية، بما يضمن دعم مسئولية إدارة المدرسة ومجالسها نحو تجويد مخرجاتها من الطلاب. وذلك في ظل شمول برامج التنمية المهنية والإدارية كافة الكوادر العاملة بالمدرسة. وتدعيم الروابط والتفاعل والمشاركة بين فريق إدارة المدرسة والمعلمين وأولياء الأمور وكذا المهتمين بقضايا التعليم على صعيد المجتمع المحلي المحيط بالمدرسة، مما يتيح فرصة تحديد العوامل المسهمة في خفض الأداء بالمدرسة وتفسيرها بموضوعية كبيرة، ومن ثم صياغة مجموعة من الحلول الابتكارية للقضاء على هذه العوامل وبما

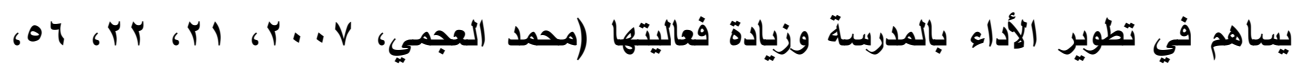

هذا إلى جانب تغيير ثقافة المدرسة بثكل إيجابي يضمن هذا التفاعل البناء، ويتيح فرصة تبني أدواراً جديدة تدعم اللامركزية وتضمن مزيدا من العلاقات الإيجابية بين المنزل والمدرسة والمجتمع المحلي المحيط بها، وتوثيق الصلة بينهم بما يضمن تحقيق المشاركة المجتمعية في إدارة وتمويل العلية التعليمية، فها المدخل يهذف إلى تحقيق الربط بين الأنثطة التي تقدمها المدرسة ومتطلبات المجتمع المحيط بها، وتلبية احتياجاته. بالإضافة إلى تهيئة البيئة المدرسية المجتمعية القائمة على المشاركة والالتزام، مما يزيل من الإحساس بالاقتدار والجدارة والثعور بالملكية والالتزام بين المشاركين، والقدرة الفائقة على الإنى الإنجاز. وتحسين عملية صنع القرار المدرسي. وتحفيز العاملين فيها نحو حتمية التجويد

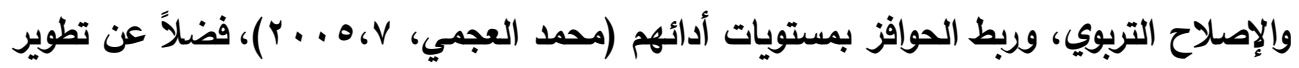
الرقابة الأتية والمحاسبية والمساءلة التعليمية لكافة العاملين داخل المدرسة، وحول استخدام الموارد، وذلك من خلال الاتفاق معاً على مواصفات الأداء الفعال، وإحداث تغيير جذري بنقل واتله سلطات معينة من الإدارة التعليمية إلى مدير المدرسة، وضرورة الاهتمام ببيئة المعلم والمتعلم.

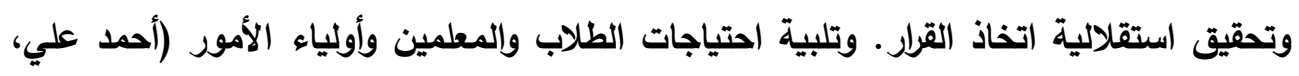

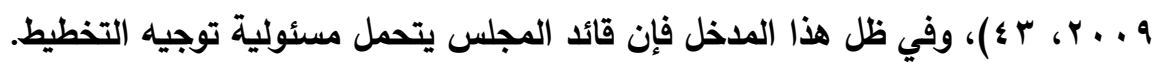
هذا إلى جانب أن هذا المدخل يهدف إلى زيادة وعي العاملين بالتشريعات المنظمة لعملهم، وتفعيل تطبيق اللوائح المرتبطة بأساليب الثواب والعقاب حسب مستوى الأداء، وتفعيل دور 
دراسة إثنوجرافية لمجالس الأمناء والآباء والمعلمين --------- د / هند سيد أحمد

أعضاء المدرسة من خلال تشجيعهم على العمل الجماعي، ورفع روحهم المعنوية عن طريق توفير السلطة والحرية والمرونة والموارد، وذلك للنهوض باتخاذ الإجراءات السربعة وإلمناسبة، لحل المشكلات التعليمية الخاصة بالمدارس على نحو مستقل. وتههف لامركزية الإدارة إلى تحقيق التطوير والتميز الإيجابي في أداء كل من الطلاب والمعلمين، وتوفير نظم التغذية الراجعة لكل منهم بصفة مستمرة، بتحديد نقاط القوة ونقاط الضعف. بجانب العمل على تطوير القدرات الإدارية والتنظيمية والمالية للمدرسة ككل (نجوى

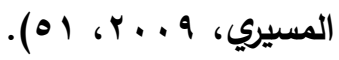
وتأسيساً على ما سبق يتضح أن أهداف مدخل لامركزية الإدارة ترتكز على تحقيق كفاءة إدارة المؤسسات وبالتالي تعرف المشكلات التي تواجهها أثناء تحقيق المسئوليات التي تقع على عاتقها؛ مما يتطلب إثراك جميع العاملين في المؤسسة مع أفراد المجتمع الخارجي في مناقثة جميع الموضوعات والقضايا المتضمنة في مسئولياتها، وبالتالي المشاركة في اتخاذ القرار وإعطاء فرصة للإبداع والابتكار لتحقيق التميز وتحقيق الجودة في القيام بالمسئوليات. وفي إطار تركيز الاراسة على مدخل لامركزية الإدارة فإن الأمر يتطلب تناول أهمية هذا المدخل على النحو الآتي: r- أهمية مدخل لامركزية الإدارة في تعزيز المسئولية بالتعليم إن تكامل أدوار كل من الأفراد ومنظمات المجتمع يساعد على تحقيق المسئولية بالتعليم؛ ولذلك يمكن تناول أهمية مدخل لامركزية الإدارة من خلال ثلاثة جوانب، الأول: أهمية هذا المدخل لأعضاء مجالس الأمناء (كأفراد)، والثاني: أهمية هذا المدخل للمؤسسات التعليمية، والثالث: أهمية هذا المدخل للمجتمع ككل. الجانب الأول: أهمية مدخل لامركزية الإدارة لأعضاء مجالس الأمناء (كأفراد): إن لأعضاء مجالس الأمناء الحق في المشاركة المجتمعية في العملية التعليمية، وبالتالي فإن للمجلس مسئولية حسب ما يملكه من سلطات ومعارف، فهذا المدخل يزود الأعضاء بالسلطة والآليات التي تمكنهم من حل المشكلات؛ من خلال الثعور بالاستقلال وحق التصرف وحرية الأداء.

إن استخدام أعضاء مجالس الأمناء والآباء والمعلمين لمدخل لامركزية الإدارة يكون مفيدا لهم

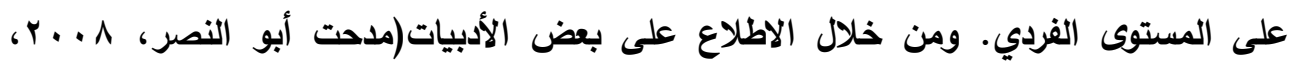

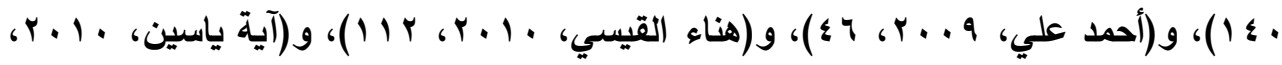




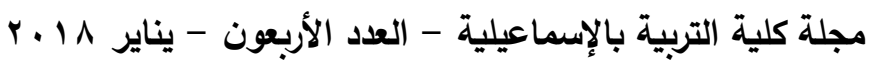

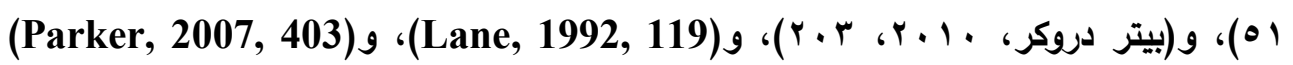
تبين أن الإدارة الفعالة للذات تؤدي إلى توفير الوقت واستثماره، والإفادة من الفرص من خلاله. وحسن إدارة الذات يجعل الشخص ذا شخصية قوية وإيجابية وفاعلة بما يسهل وييسر لله عملية إدارة الآخرين وقيادتهم بثكل سليم ومناسب، فهذا المدخل يسمح بحسن إدارة الوقت. إن مدخل لامركزية الإدارة يعتبر مجال للتدبر والتفكر، فهو يساعد على حثد القوى المادية والمعنوية والعقلية، من خلال جمع المعلومات والتدريب وإعداد الخطط. كما أن مبدأ الثورى الإدئي والمشاركة في اتخاذ القرار الذي يقوم عليه هذا المدخل يساعد على وضع الحلول والمقترحات للمشكلات، حيث يراعى التنوع والحق في إصدار قرارات متناسبة مع البيئة، الأمر الذي يشجع التطوير والتجويد بتقديم المقترحات البناءة. كما يؤدي إلى تحقيق رضا العاملين، ويعمل على رفع الروح المعنوية لهم. وتحفيزهم ويفتح المجال لزيادة خبرة الأفراد والتعلم من خلال العمل، كما أن لن هذا المدخل يساعد على تنمية روح المنافسة لاى الأعضاء، وتنمية مهارة صنع القرار، وبالتالي تنمية قادة جدد. ولأن المنظمات تبنى على الثقة؛ فهذا المدخل يجعل الأعضاء يثق كل منهم في الآخر، ويعتمد كل منهم على عمل الآخر، ويتحمل كل عضو مسئولية العلاقات مع أي فرد يعمل معله، وبالتالي لإني فهو يعمل على تنمية روح التعاون بين كافة العاملين بالمدرسة وأفراد المجتمع المحلي المحيط بها، وتعزيز الترابط والتلاحم بين كافة فئات العمل المدرسي. ويؤدي إلى زيادة الاهتمام بالعمل

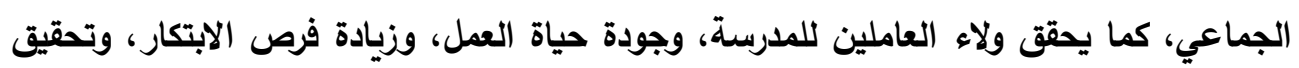
السلوك المقبول (تعديل السلوك الاجتماعي)، وإثبات الذات وروح الانتماء، والتفهم والمشاركة الوجدانية بين الأعضاء. كما أنه مجال خصب لتعلم الأفراد الكثير من مبادئ السلوك الاجتماعي والمشاركة الاجتماعية والتي يتم من خلالها اكتساب القيم والاتجاهات والخبرات والمهارات المرتبطة بالممارسة الإدارية، وهذا يؤدي بدوره إلى تنمية القدرة على اتخاذ القرارات وتحمل المسئوليات بوعي وكفاءة وبالتالي تحقيق هذه المسئوليات. الجانب الثاني: أهمية مدخل لامركزية الإدارة للمؤسسات التعليمية: إن اللامركزية التي يقوم عليها هذا المدخل والتي تتضمن توزيع السلطة (تحقيق ديمقراطية الإدارة من خلال تفويض الصلاحيات) تعمل على زيادة المشاركة. وبالتالي يتوزع العبء على لونى جميع الأعضاء في مجلس الأمناء. كما يمتد ليثمل أفراد المؤسسة التعليمية ككل مما يسمح 
بزيادة قنوات المشاركة الثعبية، ويشجع المرونة والتنافس فيما بين الأفراد؛ مما يعزز من تحقيق مسئوليات مجلس الأمناء. وفي هذا الإطار يثير (Leroy, 2002) إلى أن تطبيق لامركزية

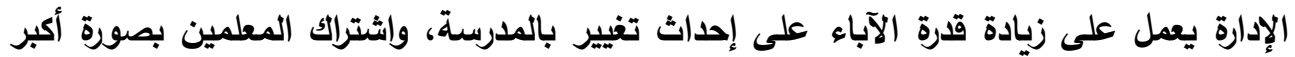
في إدارة المدرسة. وعندما يشارك أعضاء هذه المؤسسات في برامج لتنمية القيادة في إطار تطبيق مدخل لامركزية الإدارة؛ فإن ذلك يعزز العلاقات الثخصية والمهنية فيما بين الأعضاء داخل هذه

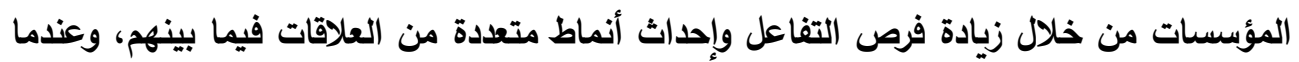
يدرك الأعضاء أهمية شبكة العلاقات فإنهم يظهرون تحسنا في الأداء. وهذا ما أكدته دراسة فان وكونستاس (Van \& Constas, 2011, 74)، فهذا المدخل يحسن الاتصالات غير الرسمية بين الأفراد في المؤسسة التعليمية. ويعتبر آلية لتحقيق التفاعل الاجتماعي والثقافي الإيجابي بين المدرسة والمجتمع. فمدخل لامركزية الإدارة يعمل على دعم المزيد من علاقات العمل بين

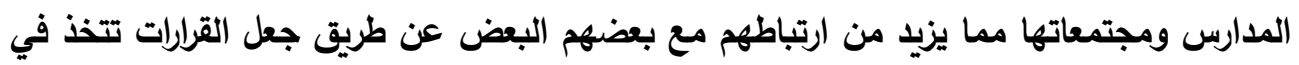

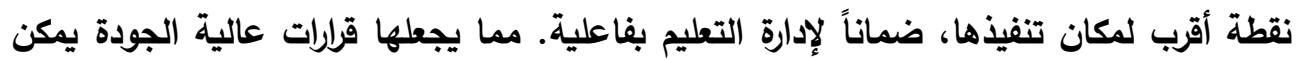

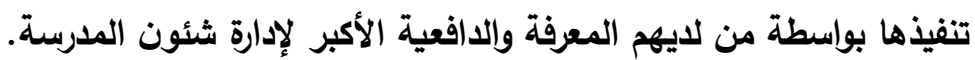
وهذا المدخل يمنح المدرسة قراً من الحرية في توظيف مدخلاتها بما يتفق وظروف المجتمع

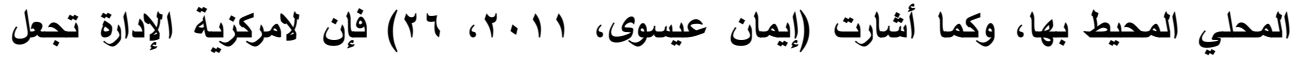
الفريق قادر على إدارة التغيير، وإدارة الجودة، وإدارة المعلومات، حيث أصبحت المدرسة جهة صنع واتخاذ القرارات وليس تنفيذها فقط. هذا وتوجد علاقة وثيقة بين التزام المؤسسات بكل من المشاركة، والثفافية، والكفاءة الإدارية؛

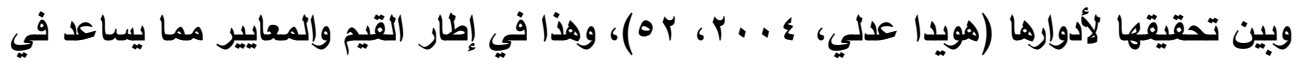
الثعور بالكفاية الأتية، والإيمان بالقدرة على تغيير المدرسة للأفضل. فالالتزام بالقيم يساعد على تحقيق الأدوار والمسئوليات. فهذا المدخل يؤكد السعي إلى المبادرة الإدارية الذاتية، وتحقيق الانضباط الإداري، وترسيخ

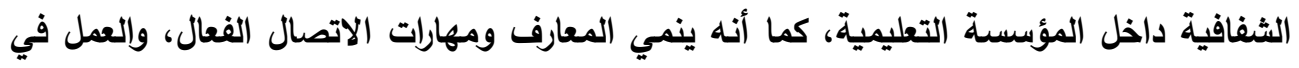
فريق وتفويض السلطة، وبناء قياداته شبكياً وأفقياً لا هرمياً. كما يمثل هذا المدخل طاقة كامنة لحث العاملين في المدرسة والمجتمع المحلي المحيط بها نحو الإصلاح التربوي لما يحثه من 


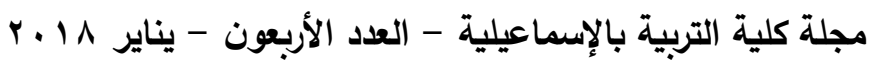
تنمية مهنية، ويوفر قادة جدد على كل المستويات مما يزيد من فعالية الإدارة. ويقدم هيكلاً مرناً

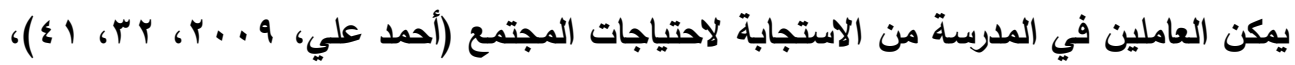
كما أن هذا المدخل يكفل للمدرسة مزيدا من الاستقلالية، ويساهم بدور فعال في ترشيد وتحسين

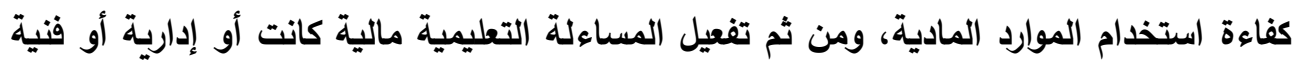

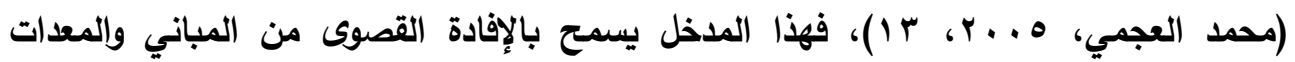
والأجهزة والإمكانات.

فضلاً عن ذلك فإن التنسيق والتنظيم والتعاون التي تعتبر من آليات لامركزية الإدارة تضمن ندرة التعارض في المصالح والأهداف وبالتالي تتحقق المسئوليات. فكما أوضحت (رانيا علي،

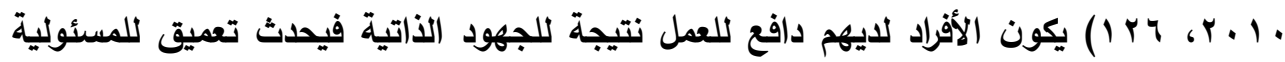
الاجتماعية، فهذه الجهود تقوم بتحقيق مطالب الأفراد حيث إنهم يعرفون ما يحتاجونه وأولوياتهم ويحاولون تحقيقها، كما أن الجهود الأتية تعمل على رفع الكفاءة الإنتاجية، واكتشاف القيادات المبدعة. إن لامركزية الإدارة تتضمن إدارة للوقت والجها والمال، وإدارة للممتلكات وإدارة لتسهيلات

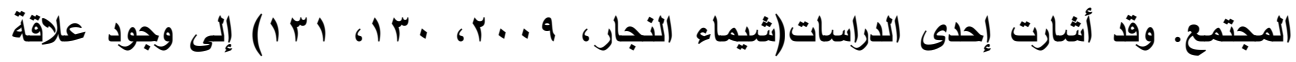
إيجابية بين إدارة هذه الموارد، وبين المستوى العام للمسئولية الاجتماعية. فكلما زادت القدرة على إدى

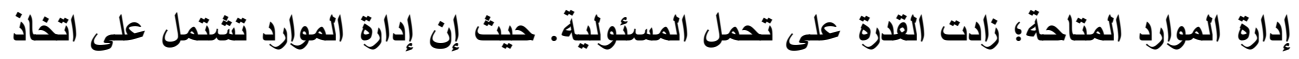
قرارات وتحمل المسئوليات. ومن هنا يتبين أن أغلب أنثطة المسئولية يمكن أن تتحقق من خلال ماخل لامركزية الإدارة. الجانب الثالث: أهمية مدخل لامركزيـة الإدارة للمجتمع: نظراً لأن الدراسة تتناول مسئولية مجالس الأمناء والآباء والمعلمين؛ والتي تعبر عن التزاماتها

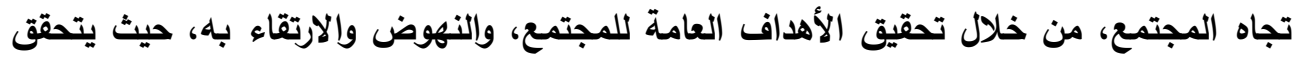
هذا النهوض والارتقاء من خلال تحقيق هذه المجالس والتي أنثئت من أجل المجتمع لأهدافها، حيث تقوم المؤسسات التعليمية بتلبية احتياجات المجتمع التعليمية؛ فلكي يحدث ذلك فالأمر يتطلب استخدام هذه المجالس لمدخل لامركزية الإدارة. الذي يساعد في إيجاد مناخ إيجابي يساعد على تحقيق أهداف هذه المؤسسات، من خلال مشاركة جميع الأفراد بداخلها، ومشاركة أفراد المجتمع الخارجي. بل ومشاركة تنظيمات المجتمع في تحقيق أهداف بعضها البعض. حيث يثير 
(خالد أمين) إلى أن مدخل لامركزية الإدارة يسهل مشاركة المنظمات المدنية في عملية التنمية

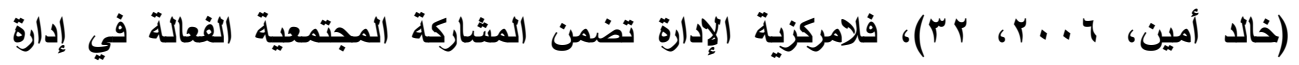

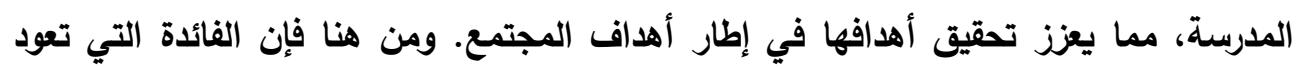
على الأفراد والمدارس من تطبيق مدخل لامركزية الإدارة؛ تعود أيضاً بالفائدة على المجتمع ككل.

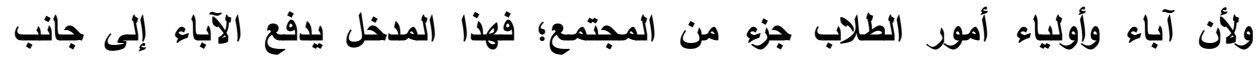

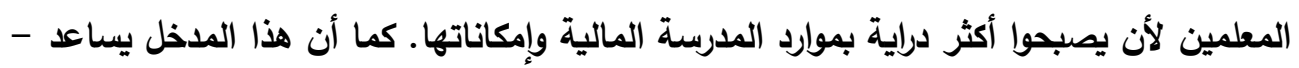
كما أشار (Lane)- في إجراء مناقثات عامة عن أحوال التعليم. بما يعود بالنفع على المجتمع.

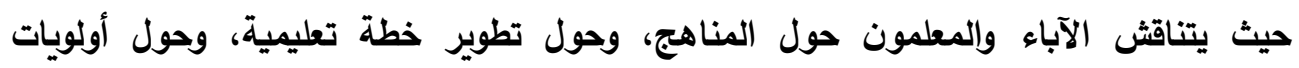
الميزانية. ومن خلال هذا المدخل يمكن التغلب على الحواجز في الاتصالات بين المعلمين وإلمدراء

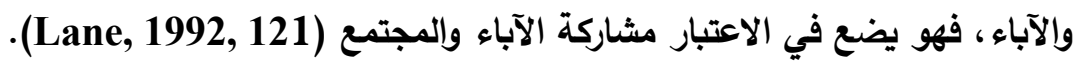
وكما أن تطبيق مدخل لامركزية الإدارة يساعد في تعزيز العلاقات الإيجابية بين أعضاء

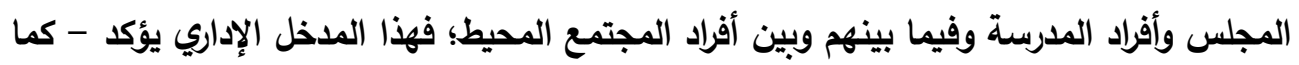

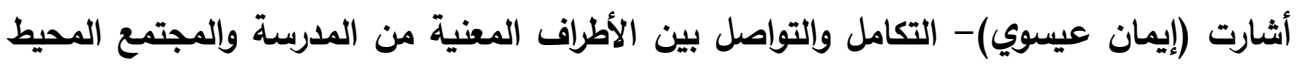

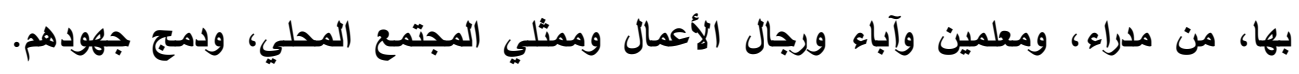

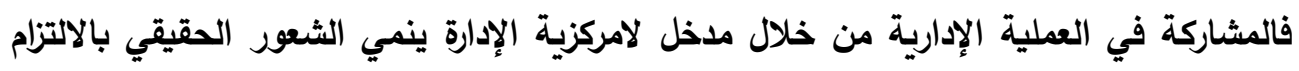

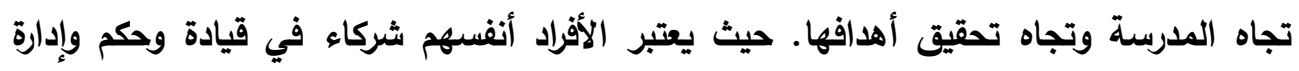

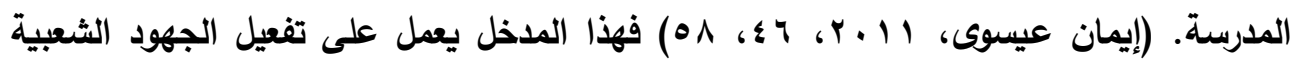
لدعم التعليم، وبالتالي تتحقق المسئولية.

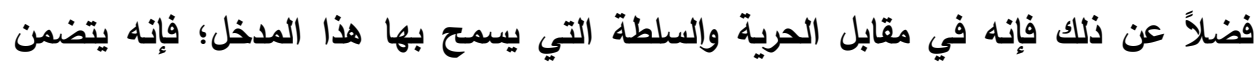

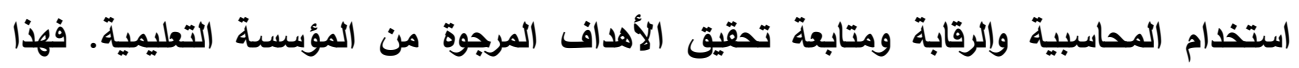

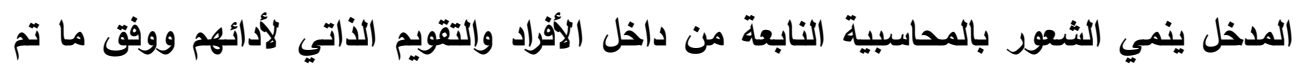
الاتفاق عليه وبالتالي تحديد أوجه القصور والضعف. فعن طريق المحاسبية يبادر الأفراد بأفعالهم

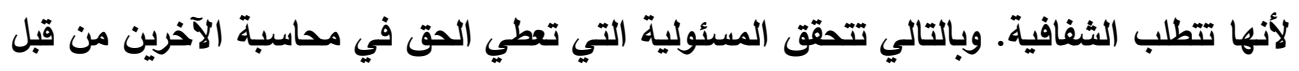

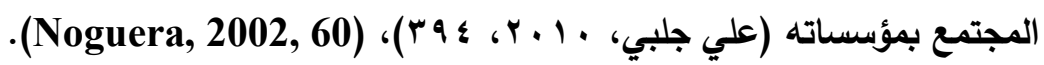

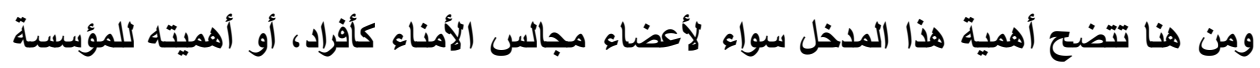
التعليمية في حد ذاتها، إلى جانب أهيته للمجتمع ككل. 


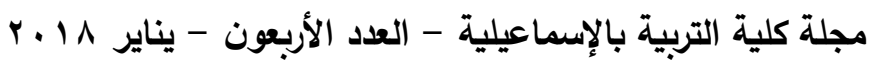
وفي إطار التركيز على مدخل لامركزية الإدارة، ونظراً لأهميته في تعزيز مسئوليات مجالس

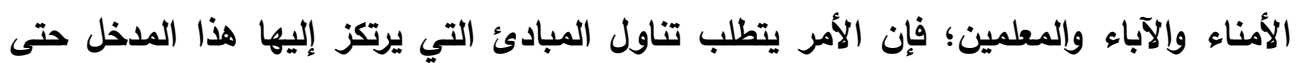
يمكن تطبيقه. فمعرفة هذه المبادئ تمثل أهم المدخلات الإدارية حتى يمكن تطبيق لامركزية الإدارة كنظام على النحو المنوط به. ثانياً: مبادئ مدخل لامركزيـة الإدارة المبادئ "هي حقائق أساسية لها صفة العمومية، وهي كذلك خطوط إرشادية وقواعد موجِهة

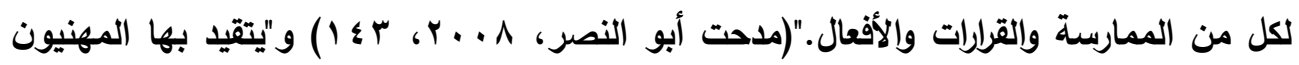

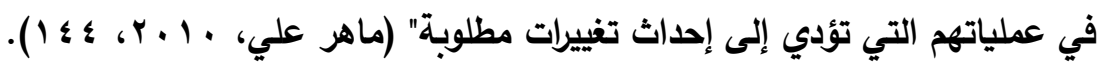

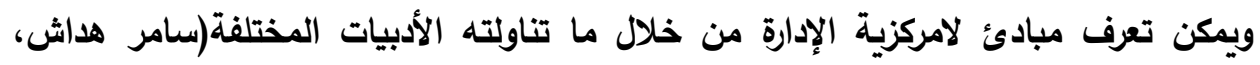

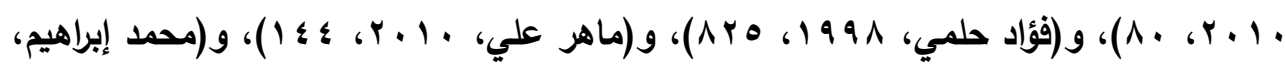

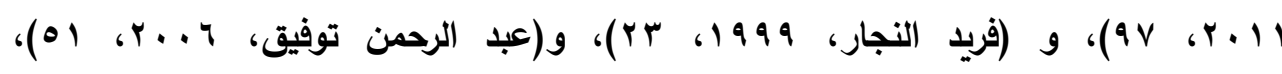

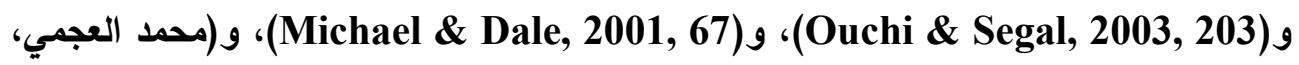

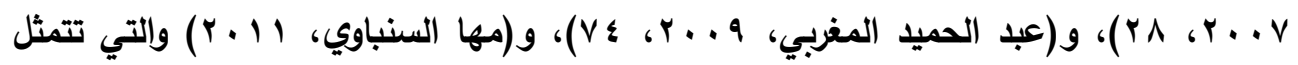
في مبدأ الالتزام بأهداف المنظمة، ومبدأ مراعاة السياق الثقافي للمجتمع، ومبدأ اللامركزية، ومبدأ المشاركة، ومبدأ (العلاقات الإنسانية (وجود رأس المال الاجتماعي)، ومبدأ الاتصال، ومبدأ الثفافية، ومبدأ التنمية المهنية والتمكين، ومبدأ المحاسبية، ومبدأ التغيير، وذلك كالآتي: ا- مبدأ الالتزام بأهداف المنظمة: فمدل لامركزية الإدارة كمثل أي مدخل إداري يقوم على

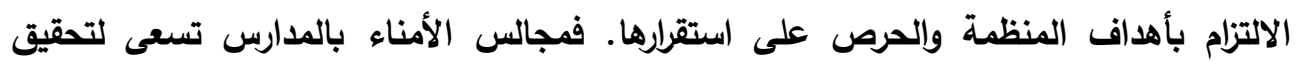
أهداف المدرسة في إطار إمكاناتها وظروفها، وظروف المجتمع الذي توجد فيه، وهذا يتطلب تحديد الأولويات وتحقيق التوازن فيما بينها، إضافةً إلى الحافز الثخصي الذي يتضمن الثيدي الطموح

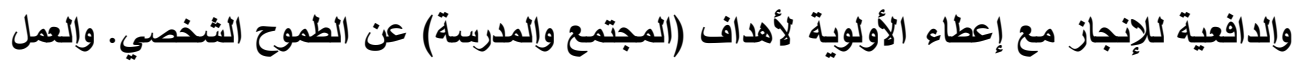
بجدية. كما يتحقق هذا المبدأ أيضاً من خلال تنمية الوعي الأتي الذي يتضمن وضوح الأهداف

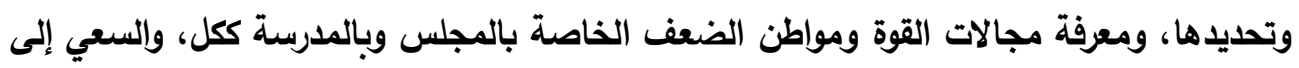
استغلال الفرص وتحقيق المسئولية وبالتالي تحقيق الأهداف. 
دراسة إثنوجرافية لمجالس الأمناء والآباء والمعلمين ---------_ / هند سيد أحمد

وهذه الأهداف تتضمن تحقيق حاجات المستفيدين، والمستفيدون هنا هم الطلاب وأولياء أمورهم والمجتمع ككل. وهذا المدخل يعمل على تحسين ظروف تعليم الطلاب، من خلال ربط الأنشطة غير الصفية كالمسابقات الرياضية بالمناخ المدعم لعملية تعليم الطلاب، وذلك لتحقيق الحد الأقصى لتعليم وإنجاز الطلاب. وفي ظل شعور المعلمين بملكيتهم للمدرسة إثر مشاركتهم في إدارتها ذاتيا يتزايد حماسهم للتدريس، وحل كافة المشكلات التي يمكن أن تجابههم، هذا إلى لتى جانب أن هذا المدخل يساعد من خلال المشاركة المجتمعية في تطوير محتوى المناهج لإنتاج تقنية عالية تخدم المجتمع. وهنا تتحقق الأهداف التعليمية والتي تعتبر من أهم أهداف المجتمع. وهذا يستدعي وجود المبدأ الآتي: r- مبدأ مراعاة السياق الثقافي للمجتمع: فعقائد الناس ووجهات نظرهم، وقيمهم وأحكامهم وخبراتهم تثكل أساس سلوكهم. وهنا حتى يتم استخدام مدخل لامركزية الإدارة بكفاءة؛ فمن المتطلب من أعضاء مجالس الأمناء الالتزام بقيم المجتمع. كما يتطلب الأمر السلوك الأخلاقي لإهي والنزاهة التي تتضمن الصبر والصمود والتعبير عن وجهة النظر بصدق، والاعتراف بالأخطاء،

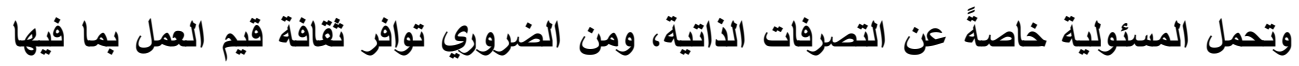
من الالتزام بالمواعيد وتأكيد حرية الأعضاء في التعبير عن أنفسهم وحقهم في المشاركة في اتخاذ القرارات. وهذا يفسح الطريق لظهور المبدأ الآتي: r- مبدأ اللامركزية: وهو يعتبر شكلاً من أثكال الحرية في التعبير عن الآراء ووجهات النظر يُمَكِّن أعضاء المجلس والمدرسة وأفراد المجتمع من المشاركة في إدارة شئون المدرسة بنفئه في ظل مناخ ديمقراطي. فهو يتضمن تحمل المسئولية لإدارة مجموعة من الأفراد بليمقراطية. كما يتضمن تبسيط الإجراءات الإدارية، ومن ثم تبسيط الجهود. ويجعل التظيم قادر على التفويض في ماتي اتخاذ القرارات، والمشاركة في تحمل المسئولية، والسلطة التي تحميها. وتحقيق اللامركزية يساعد على القضاء على المركزية المعرقلة لسير العمل. وإيجاد أكثر من حل ومقترح للمشكلات المتكرة

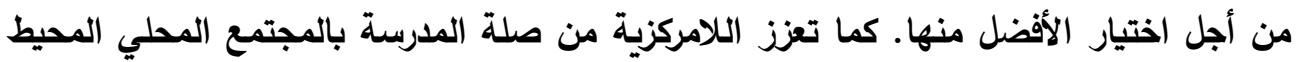
بها؛ ومن ثم تَكُون قاعدة المشاركة والمسئولية أكثر اتساعا. فهذا المبدأ يتضمن شقين الأول: هو الاستقلالية في صنع القرارات على مستوى المجلس. والثاني: هو المشاركة في صنع القرارات

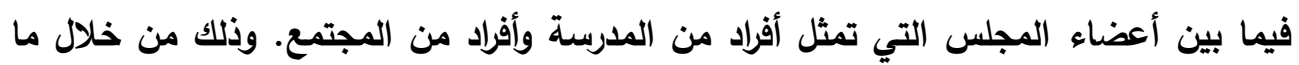

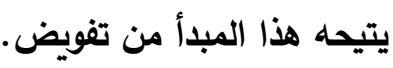


مجلة كلية التربية بالإسماعيلية - العدد الأربعون - يناير 1^ ب r

فالتفويض يقصد به أن يمنح الرئيس بعض مرؤسيه ممن يثق فيهم القيام ببعض المسئوليات

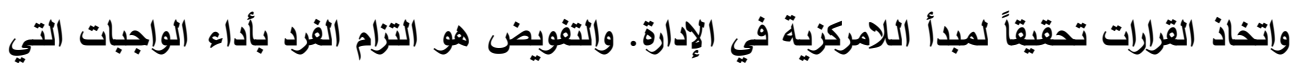
يكلفه بها رئيسه ويمارس الصلاحيات اللازمة لأدائها، ويصبح مسئولاً أمام رئيسه عما قام باه من أعمال. وبالتالي فهو عرضة للمساءلة من قبل الرئيس عن حسن استخدام السلطة، وعن إنجاز المهمة الموكولة إليه بموجب التفويض. فهو توزيع العمل على الأعضاء لغرض إنجازه. فالتفويض يتيح الحرية المطلقة في استخدام وتوزيع وتوظيف الموارد المالية وفقاً لحاجات المدرسة الخاصة وظروف البيئة المحلية.

ومن أهمية التفويض أنه يعمل على تعزيز القدرة على اتخاذ القرارات وسرعتها، ويساعد على حل المشكلات. ويخفض من العبء الناتج عن زيادة المسئوليات. ويعمل على رفع الروح المعنوية للأعضاء نتيجة شعورهم بالمشاركة الإيجابية، وبالتالي ظهور الأفكار الجديدة والعلول المبتكرة. ويهدف التفويض إلى استخراج أفضل ما لاى الأعضاء من مهارات وقدرات، فيتعين عليهم اتخاذ القرار وإجراء التعديلات إذا ما استجدت أمور تستدعي ذلك. وهو ما يعني ضرورة إنثاء

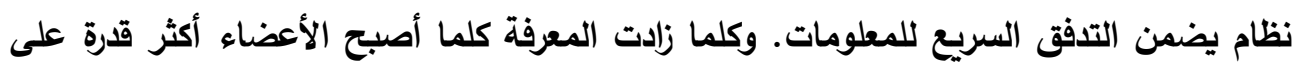
إدارة شئون المجلس على نحو مستقل. ومن هنا فإن مجلس الأمناء بالمدارس يتمتع بالمرونة والتحرر من السلطة العامة؛ بما يتناسب مع ما تم تفويضه من مسئوليات مثل رسم خطط تحسين المدرسة، والتحكم في ميزانيتها.

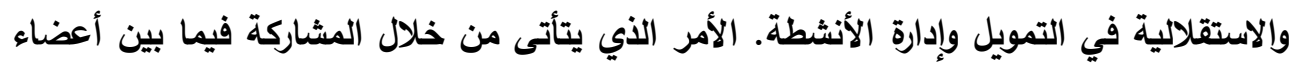
المجلس، وفيما بين المدرسة والمجتمع الخارجي. צ - مبأ المشاركة: ويقوم على التعاون بين جميع الأفراد المهتمين بالعملية التعليمية سواء من المجتمع الداخلي للمدرسة (مدير المدرسة، والمعلمين، والطلاب، ...) أو من المجتمع المحلي لإلي الخارجي (الآباء، ورجال الأعمال، وأعضاء الجمعيات الأهلية، ...). فيتم فتح مجال للحوار والمناقشة فيما بينهم، بما يعمل على تقريب وجهات النظر فيما بين المجتمع الداخلي والخارجي للمدرسة. وينظم هذا التعاون والمشاركة مجالس الأمناء والآباء والمعلمين بالمدارس والذي يضم لئم ممثلين من هؤلاء الأطراف. فيتم تحديد الأدوار والمسئوليات ومنح صلاحيات لتنفيذ الأهداف. والمشاركة لها أشكال منها تمثيل الأفراد في مؤسسات تعتمد على العضوية مثل الجمعيات الأهلية. أو في شكل انتخاب الممثلين من مجالس الأمناء بالمدارس. أو المشاركة في تجميع 
البيانات وتقديمها في تقارير • وتظهر أيضاً المشاركة في الإفادة من المباني المدرسية في تدعيم

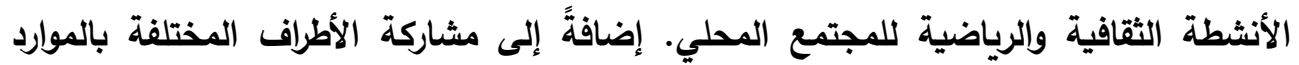
والأموال فيما يطلق عليه التمويل الذاتي الذي يستقل عن التمويل الحكومي. فضلاً عن المشاركة

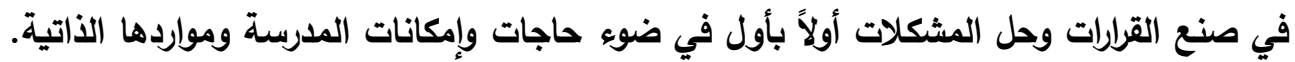
ومن هنا فإن صناعة القرار والمسئوليات تحتاج إلى تضافر جهود كل المشاركين.

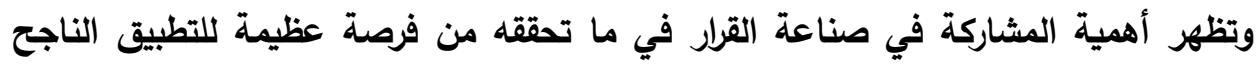

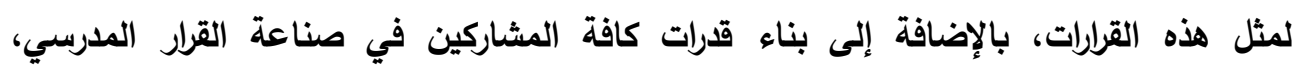
وتأهيلهم لتحمل المسئولية، ورفع مستويات الوعي بينهم بحقيقة المشكلات الاجتماعية والتعليمية والتي تستلزم ضرورة تكاتف الجهود والتقرات والموارد للتظلب على هذه المشكلات. ومن خلال

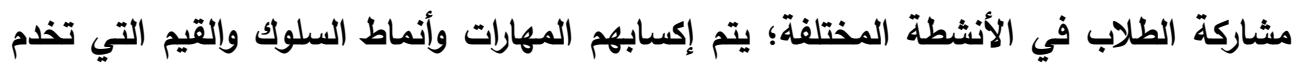

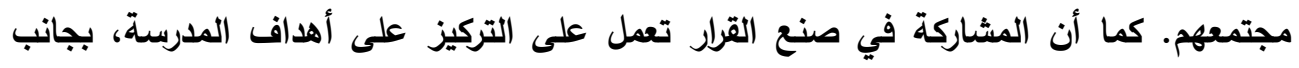

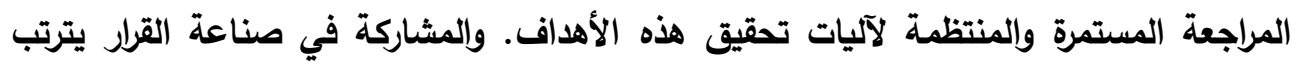

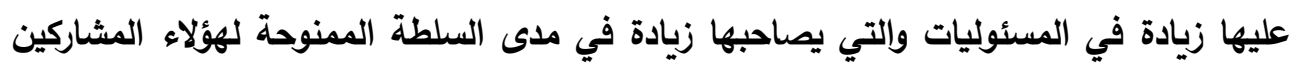
في صناعة القرارات. وهذا يتوقف على قائد المجلس وأن يكون ديمقرطياً تثاركيا يعمل من خلال الترغيب وإلحث

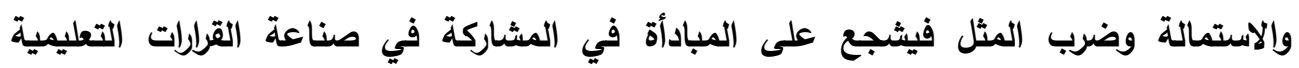

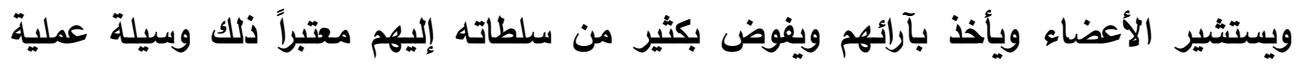

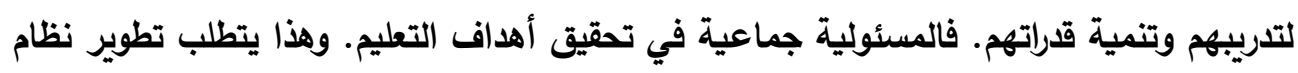

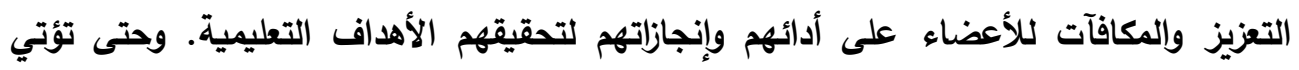

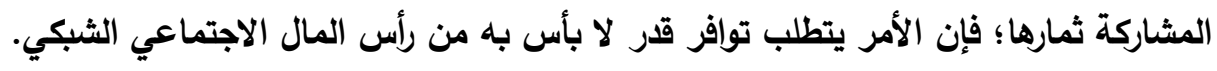

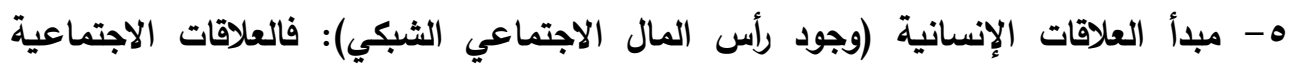

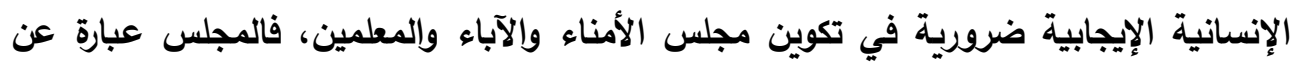

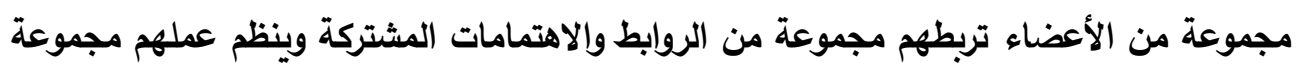

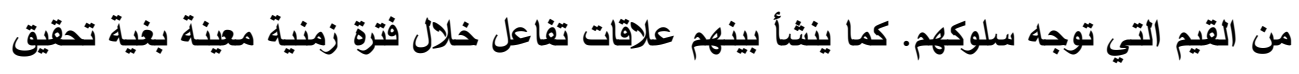

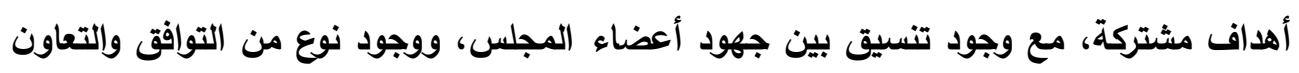
في الاتجاهات بين الأعضاء. كما أن العلاقات الإنسانية الإيجابية الهادفة التي تبني على التهل التقبل 
مجلة كلية التربية بالإسماعيلية - العدد الأربعون - يناير 1^ ب r والتعاون والاحترام المتبادل والمسئولية المشتركة تعتبر الأساس للإدارة الايمقراطية. ومن ثم تحقيق المسئولية. وهذه العلاقات من الضروري تكوينها داخل المجلس وخارجه في المدرسة، بل ومع أفراد المجتمع الخارجي. وذلك لأن أعضاء المجلس يتأثرون بكل من العاملين بالمدرسة،

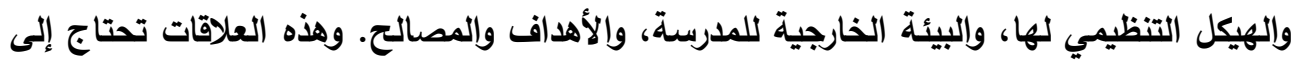
إدارة فيما يطلق عليه إدارة العمل الجماعي. فالقدرة على إدارة العمل الجماعي Teamwork competency Management مطلوبة لإنجاز المهام والمسئوليات، خاصةً في الجماعات الصغيرة مثل مجالس الأمناء، ومن ثم تحقيق المسئولية، حيث يوجد اعتماد متبادل فيما بين الأعضاء وبعضهم البعض. والقدرة على إدارة

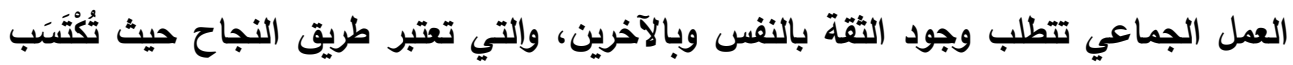
من خلال العلاقات مع الآخرين وتكمن في القيم والمعتقدات. كما تتطلب إدارة العمل الجماعي توافر ثقافة الحوار وثقافة وروح العمل الجماعي، وتوافر مهارات التفاوض، وحل الصراع، وإدارة الوقت، وتثخيص المشكلات وابتكار بدائل لحلها. وأن يكون رئيس المجلس ميسراً ومنسقاً وقائداً

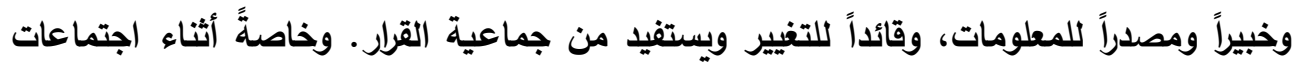

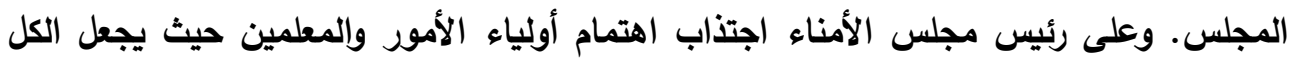
مستعدون للاجتماع في جو من الثقة. وهذا كله يحدث من خلال الاتصال الجيد.

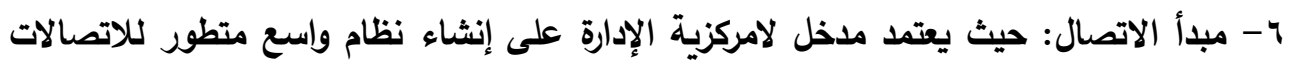
واستخدام قنوات اتصال فعالة لتدفق المعلومات حتى يتسنى لأعضاء المجلس، بل وأعضاء المدرسة المعرفة بقرارات المجلس عن تنظيم المدرسة، وأدائها وإنجازاتها، وإنجازات المجلس. وحتى يتحقق مبدأ الاتصال فمن الضروري توافر مهارات الاتصال فيما بين أعضاء المجلس، إلى لمانى جانب وضوح الأهداف وتحديدها. بالإضافة إلى أن يكون الاتصال مفتوحاً فيما بين الأعضاء، وهذا يتحقق من خلال الثفافية. - V - مبدأ الثفافية: وتعني العلنية في مناقثة الموضوعات، وحرية تداول المعلومات بثأن مفردات العمل. وإتاحتها ونشرها لأعضاء المجلس، وللعاملين بالمدرسة، حتى يكونوا على دراية

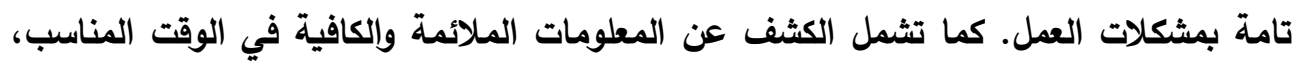
والثفافية تعني الوضوح الذي يؤدي إلى فهم اللوائح والسياسات، والتعليمات، مما ييسر من تطبيقها وتنفيذها، ومن ثم تحقيق الأهداف التعليمية، وبالتالي تحقيق المسئولية. التي تحتاج 
دراسة إثنوجرافية لمجالس الأمناء والآباء والمعلمين ---------_ د هند سيد أحمد

أيضاً إلى تمكن أعضاء المجلس بل والعاملين في المدرسة من أداء المهام والمسئوليات التي تقع على عاتقهم بفاعلية ـ وهذا يحدث من خلال المبأ الآتي:

1 - مبدأ التنمية المهنية والتمكين: فالتمكين يعني توسيع قدرات أعضاء المجلس، وتحويلهم إلى عناصر ديناميكية فاعلة تتمتع بالقدرة على اتخاذ القرار، والتحليل والتعلم من خبرات الحياة

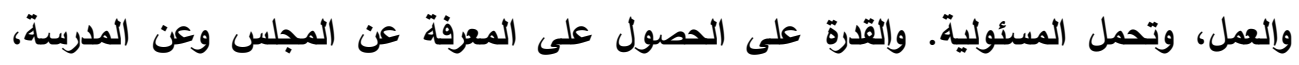
وتطبيق السلوكيات والأساليب. في ظل إتاحة الموارد، وإعطائهم سلطات حل المشكلات (التفويض)، وتنفيذ الحلول التي يتوصلون إليها (اللامركزية). ومشاركتهم في وضع أهداف المجلس وتنفيذها، وإتاحة المعلومات، وبناء الثقة من خلال المشاركة. وبالتالي دعم وتعزيز مسئوليتهر عن العملية التعليمية. وحتى يتم تنمية قرات أعضاء المجلس وتمكينهم؛ فإن الأمر يتطلب تنميته مهنياً، وتنمية بصيرتهم واستتتاجاتهم. والتنمية المهنية هي مجموعة من الإجراءات المخططة والمنظمة والتي ينتج عنها زيادة وتحسين المعارف والمفاهيم والمهارات لاى الأعضاء وتنمية اتجاهاتهم وقدراتهم التي تمكنهم من تحملهم لمسئولياتهم. وتتضمن تحديد الاحتياجات التدريبية، بجانب مساهمة

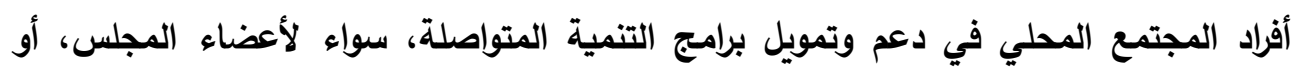
العاملين بالمدرسة. وتوفير المراجع اللازمة للنمو المهني. بالإضافة إلى التدريب على مهارئ مهارات استخدام التكنولوجيا المعاصرة في الإدارة. وذلك بهدف تنمية قدرات جميع العاملين وتنميتهم مهنياً ومهارياً وفكرياً، وتدريبهم على عمليات صناعة القرارات التعاونية على أن يكون هذا التدريب وهذه التهات التنمية مستمرة حتى يتم إكسابهم الخبرة التي تمكنهم من اتخاذ القرارات التعليمية. كما يتطلب الأمر تدريب أعضاء المجلس على التقويم الذاتي والرقابة الذاتية من خلال استعراض الأخطاء كفرص للتعلم. وهذا ما يتضح من خلال المبدأ الآتي: لآي التئ 9 - مبدأ المحاسبية (المساءلة): فالمساءلة هي الوجه الثاني للمسئولية، فحتى تتحقق المسئولية

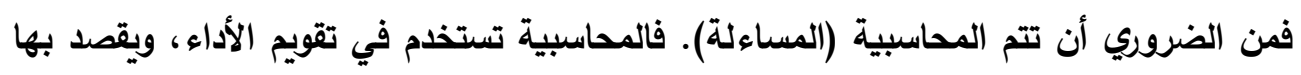
المجال الذي يكون فيه الإدارة والعاملين مسئولين أمام سلطة أعلى (سواء كانت تثريعية أو تنظيمية) عن أفعالهم ونتائج قراراتهم، كما تتضمن أيضاً أن يقدم الإدارة والعاملين البراهين على الإلى أن البرامج التي تم إتباعها قد اتسقت مع الأهداف الموضوعة وأسهمت بفاعلية في تحقيقها. فهناك شقين للمساءلة، شق إيضاحي أو تفسيري، وآخر تبريري. فهي توجب تحديد ما تم إنجازه، 


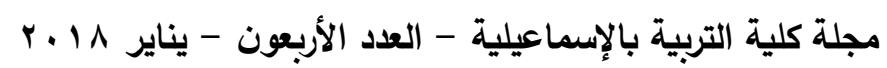
والكشف عن مبررات الفشل في تحقيق الأهداف المخطط لها. وفيها يتم تحديد مسئولية كل فرد عن النهوض بأعمال ومهام بعينها، وكذا تحديد من سيقوم بمساءلته.

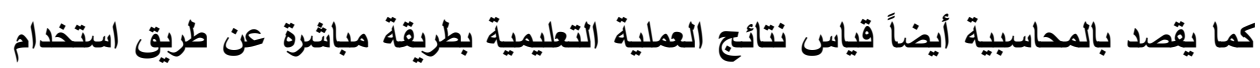
معايير موضوعية في إطار نظام تعليمي يعتمد على تحقيق الأهداف، ويهتم بالفاعلية أكثر من اهتمامه بالكفاية في التعليم، حيث تهتم المحاسبية بجودة الأداء وتتجه نحو نتائج العمله العملية

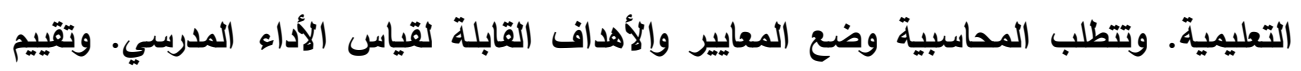
ومراقبة التقدم نحو تحقيق هذه الأهداف. واستخدام البيانات لتحديد مواطن القوة لزيادة تحسينها،

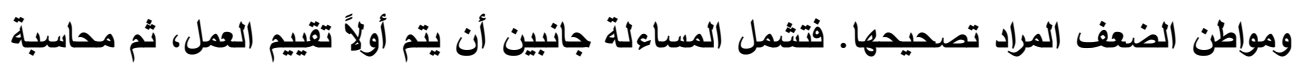
القائمين عليه. وغالبا ما تكون المساءلة مرتبطة بمكافأة أو بعقوبة. والمحاسبة لها أبعاد هي: الأول: هو المساءلة التقليدية وتعني التأكد من اتساق الععل مع دعائه

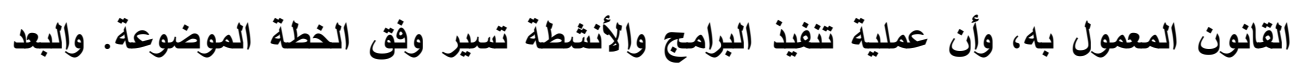
الثاني: محاسبة تفويض السلطة وهي معرفة مدى تحقيق أعضاء المجلس لأدوارهم ومسئولياتهم في اتخاذ القرارات. والبعد الثالث: محاسبة مهنية وهي مدى التزام أفراد المدرسة مهنياً وإدارياً وتربوياً في تحقيق أهداف المدرسة ومشاركتهم في قيادة المدرسة. أما البعد الرابع: محاسبة مدية مجتمعية ويتم فيها محاسبة المدرسة لما تم تحقيقه من مخرجات التعليم واعتبار حق المجتمع فئي المحلي في معرفة مدى تحقيق المدرسة لأهدافها وما أنجزته. كما تعني التأكد من أن الأنشطة

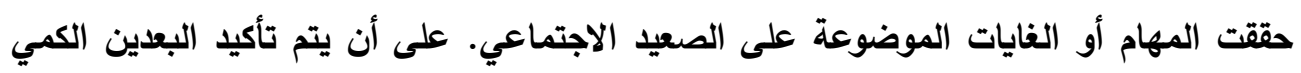
والكيفي للعمل. وتكون هنا المساءلة من قبل المواطنين للقادة وذلك عن طريق المجتمع المدني، أو الأحزاب السياسية أو الاجتماعات العامة التي يشاركون فيها، وهذا ما يتم من خلال مجالس

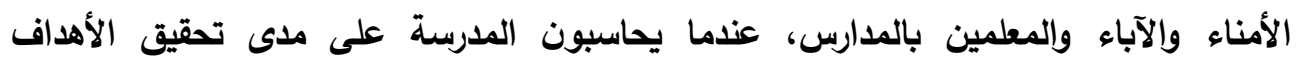
التعليمية.

فالمسئولية مشتركة بين المجتمع والمدرسة بكافة أفرادها في تحقيق المدرسة رؤيتها ومحاولة تنفيذ رسالتها ومدى فهم الأدوار والمسئوليات الخاصة بكل فرد، ومنح المدرسة وقتاً لتنفيذ خطة فئه التحسين ثم محاسبتها. سواء من قبل الإدارات التعليمية العليا أو من قبل مجالس الأمناء والآباء

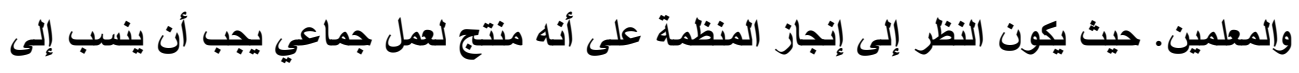
كل فريق العمل بأسره وليس إلى شخص بعينه، ويقتضي ذلك أن تنثط المسئولية الجماعية في 
دراسة إثنوجرافية لمجالس الأمناء والآباء والمعلمين --------- د / هند سيد أحمد

تحمل الأخطاء ومحاولة تصويبها. فيتطلب الأمر وجوب المساءلة التعليمية الموضوعية الشاملة لكافة الأطراف المشاركة في العمل التعليمي. ولكي تتم المساءلة يتم جمع المعلومات والتفسير والحوار وتحديد مساحة القبول العام. وتتم المساءلة على مستويين الأفقي والرأسي فالمساءلة الأفقية تقوم بها جهة أو شخص يتمتع بنفس القدر من المساواة مع الجهة التي تخضع للمساءلة، أما الرأسية تقوم بها جهة أو شخص يتمتع بسلطة ووضع متميز في مواجهة الجهة أو الثخص الذي يخضع للمساءلة. وفي حالة مجلس الأمناء بالمدارس فيخضع أعضاء هذا المجلس لمحاسبة ذاتية، حيث يقوم بإعداد التقارير

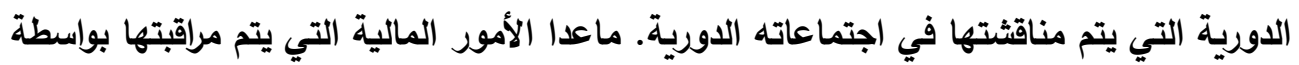
المراقب المالي. فمجس الأمناء والآباء والمعلمين يمارس رقابة مجتمعية على المدرسة، ويمارس رقابة ذاتية على نفسه. وفي كل الأحوال بعد أن تتم المحاسبة فإن الأمر يتطلب تغيير الأوضاع لكأفضضل. • 1 - مبدأ التغيير: فلامركزية الإدارة تتطلب تغييرات مستمرة في الإطار الهيكلي للمجلس. وفي

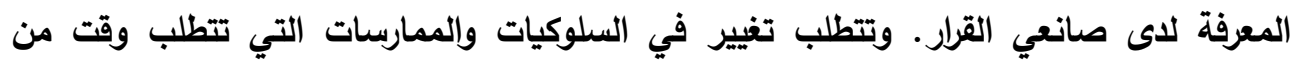
أعضاء المجلس للتكيف معها. وذلك إذا أثتبت المساءلة وجود قصور أو ضعف في أي من هذه الأمور. وذلك رغبةً في الوصول إلى الأفضل، والوصول إلى جودة الأداء بما يحقق أهداف هذه ودئ المجالس ومن ثم الأهداف التعليمية وبالتالي تحقيق المسئولية. وتأسيساً على ما سبق من تحديد المبادئ التي يقوم عليها مدخل لامركزية الإدارة؛ فإن هذه الهابه

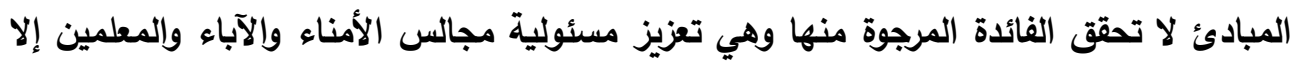
إذا وضعت موضع التففيذ. ومن هنا يعرض الجزء الميداني واقع تحقيق مبادئ لامركزية الإدارة بمجالس الأمناء ببعض المدارس بمحافظة المنوفية. وذلك من خلال تطبيق أداة الدراسة الإثنوجرافية وهي بطاقة المقابلة، وباستخدام الملاحظة بالمعايشة.

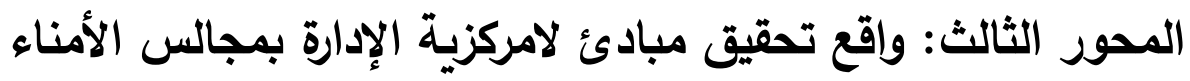
والآباء والمعلمين (دراسة إثنوجرافية) يتضمن هذا المحور هدف الاراسة الإثنوجرافية، وإجراءاتها والتي تشمل: مجتمع الدراسة، وعينة الدراسة وتحديد خصائصها، وتصميم الأداة المستخدمة (بطاقة المقابلة)، كما يتضمن 
مجلة كلية التربية بالإسماعيلية - العدد الأربعون - يناير 1^ ب r إجراءات تطبيق الدراسة الإثنوجرافية، ونتائجها المتمثلة في واقع مجالس الأمناء والآباء والمعلمين بمحافظة المنوفية. أولاً: هدف الدراسة الإثنوجرافية يتحدد هدف الدراسة الإثنوجرافية في الوقوف على واقع تحقيق مبادئ مدخل لامركزية الإدارة بمجالس الأمناء والآباء والمعلمين ببعض مدارس الإنوراهـ محافظة المنوفية.

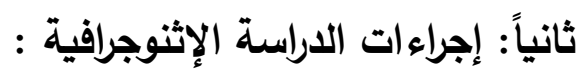
وتثمل مجتمع الاراسة، وعينة الدراسة وتحديد خصائصها، وتصميم الأداة المستخدمة (بطاقة (المقابلة).

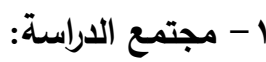

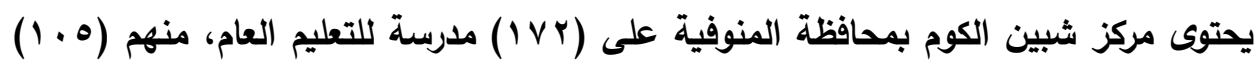

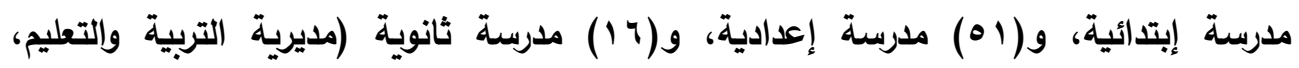
$\cdot(r \cdot 17$ r أعضاء مجالس الأمناء والآباء والمعلمين ببعض المضائه المدارس الابتدائية، والإعدادية، والثانوية بمركز شبين الكوم بمحافظة المنوفية (كدراسة حالة). وصف عينة الاراسة: قامت الباحثة باختيار ثلاث مدارس بالريف؛ الأولى ثانوية، والثانية إعدادية، والثالثة للتعليم

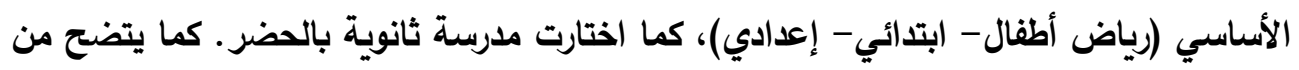

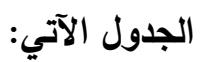
جدول رقم (1): عينة الدراسة (مجالس الأمناء والآباء والمعلمين)

\begin{tabular}{|c|c|c|c|c|}
\hline النسبة لكل مدرسة & أعضاء مجلس الأمناء المفحوصين & المنطقة التي توجد بها & المدرسة & s \\
\hline$\%$ \% , \& & 0 & ريف & حسين عزت الثانوية المشتركة & 1 \\
\hline$\% 0,9$ & 1 & ريف & محمد السيد الثنواني الاعدادية المشتركة & r \\
\hline$\%$ \% , & • & ريف & عبد العزيز عيسى الصعيدي للتعليم الأساسي & $r$ \\
\hline$\%$ \% r,r & 9 & 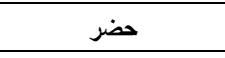 & المساعي المشكورة الثانوية العسكرية & $\varepsilon$ \\
\hline$\%$ & iv & & الإجمالي & \\
\hline
\end{tabular}


دراسة إثنوجرافية لمجالس الأمناء والآباء والمعلمين --------- د / هند سيد أحمد

يتبين من الجدول رقم (1) أن عدد المفحوصين الذين تم إجراء المقابلة معهم هو (IV) مفحوصا، كما هو موضح بالجدول. جدول رقم (ץ): وصف العينة (أعضاء مجالس الأمناء والآباء والمعلمين) هورل)

\begin{tabular}{|c|c|c|c|c|c|c|c|c|c|c|}
\hline \multicolumn{5}{|c|}{ غير إدارية } & \multicolumn{5}{|c|}{ إدارية } & \multirow[t]{3}{*}{ الوظيفة } \\
\hline \multicolumn{3}{|c|}{$\%$} & \multicolumn{2}{|c|}{$ت$} & \multicolumn{2}{|r|}{$\%$} & & \multicolumn{2}{|c|}{$ت$} & \\
\hline \multicolumn{2}{|c|}{$\% \vee \vee, 0$} & & \multicolumn{2}{|c|}{ ir } & \multicolumn{2}{|c|}{$\%$ \%r,o } & & \multicolumn{2}{|l|}{$\varepsilon$} & \\
\hline \multicolumn{5}{|c|}{ أنثى } & \multicolumn{5}{|c|}{ ذكر } & \multirow[t]{3}{*}{ النوع } \\
\hline \multicolumn{3}{|c|}{$\%$} & \multicolumn{2}{|c|}{$ت$} & \multicolumn{2}{|r|}{$\%$} & & \multicolumn{2}{|c|}{$ت$} & \\
\hline \multicolumn{3}{|c|}{$\% 1 \vee, 4$} & \multicolumn{2}{|c|}{$r$} & \multicolumn{2}{|r|}{ \%^r, \& } & & \multicolumn{2}{|c|}{$1 \varepsilon$} & \\
\hline \multicolumn{3}{|c|}{ أعلى من بكالوريوس } & \multicolumn{4}{|c|}{ بكالوريوس أو ليسانس } & \multicolumn{3}{|c|}{ أقل من بكالوريوس } & المؤهل \\
\hline \multicolumn{2}{|c|}{$\%$} & $ت$ & \multicolumn{2}{|r|}{$\%$} & \multicolumn{2}{|c|}{$ت$} & $\%$ & \multicolumn{2}{|c|}{$ت$} & الدراسي \\
\hline \multicolumn{2}{|c|}{ \%rr,o } & $\varepsilon$ & \multicolumn{2}{|c|}{$\% \vee \neg, 0$} & \multicolumn{2}{|c|}{ ir } & - & \multicolumn{2}{|c|}{-} & \\
\hline \multicolumn{2}{|c|}{ أمين السر } & \multicolumn{2}{|c|}{ عضو أمناء } & \multicolumn{2}{|c|}{ عضو آباء } & \multicolumn{2}{|c|}{ معلم } & لدرسة & مدير & طبيعة العمل \\
\hline$\%$ & $ت$ & $\%$ & $ت$ & $\%$ & ت & $\%$ & $ت$ & $\%$ & $ت$ & في المجلس \\
\hline$\%$ \%rr,o & $\varepsilon$ & $\% 0,9$ & 1 & $\%, 0,9$ & 1 & $\% \leqslant v, 1$ & $\wedge$ & $\% \vee v, 4$ & $r$ & \\
\hline
\end{tabular}

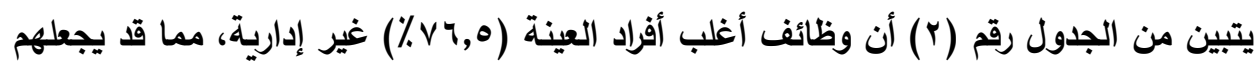

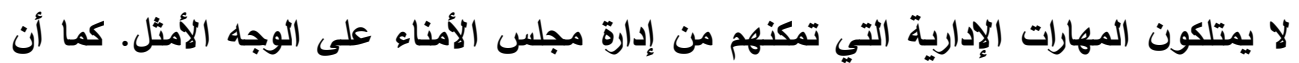

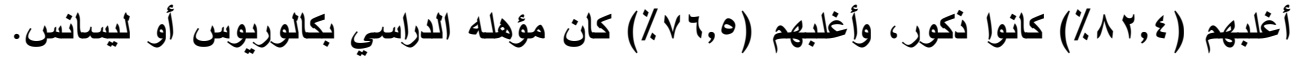

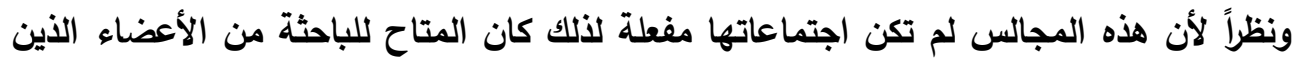

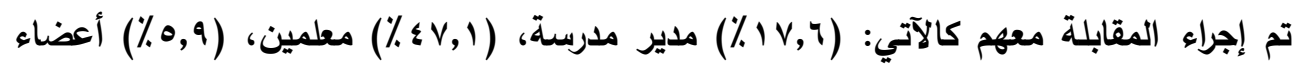

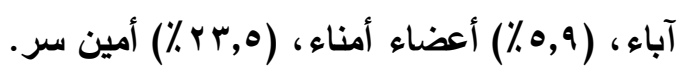
r- تصميم أداة الدراسة (بطاقة المقابلة): لتحقيق أهداف الدراسة الإثنوجرافية تم إعداد بطاقة المقابلة، التي توجه إلى أفراد العينة المكونة من أعضاء مجالس الأمناء والآباء والمعلمين ببعض المدارس، وذلك من أجل: تعرف استجاباتهم حول واقع تحقيق مبادئ مدخل لامركزية الإدارة العشرة إمبدأ الالتزام بأهداف الفئ المنظمة، ومبدأ مراعاة السياق الثقافي للمجتمع، ومبدأ اللامركزية، ومبدأ المشاركة، ومبدأ rMN 


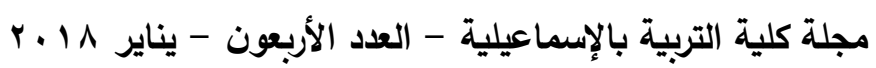

العلاقات الإنسانية (وجود رأس المال الاجتماعي)، ومبدأ الاتصال، ومبدأ الثفافية، ومبدأ التنمية

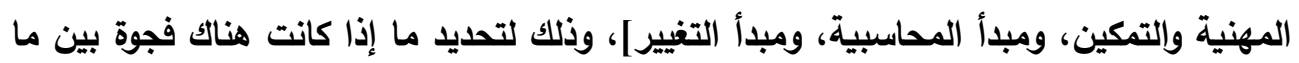

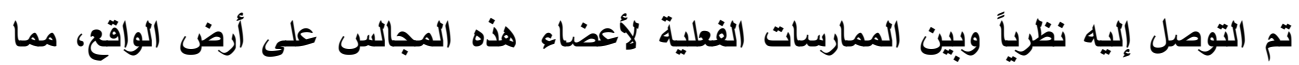
يؤثر على مدى تحقيق مسئوليات المجلس.

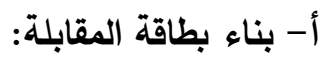

تم اشتقاق محتوى بطاقة المقابلة من الإطار النظري، وقد اشتملت في صورتها الأولية على بطى

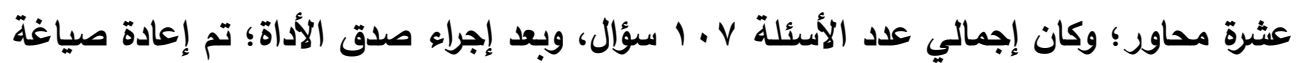

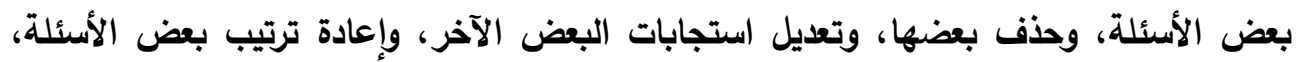

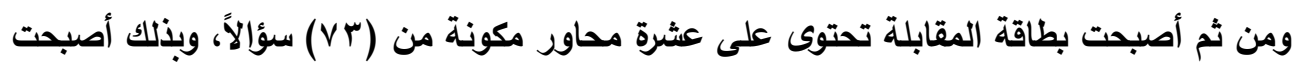
البطاقة صالحة للتطبيق. بطاقة المقابلة في صورتها النهائية: بعد إجراء التعديلات والملاحظات التي أثار إليها السادة المحكمون؛ أصبحت بطاقة المقابلة في صورتها النهائية(")، وقد اشتملت على شقين كما يأتي: الأول: بيانات أساسية: لتعرف خصائص عينة الاراسة بما قد يؤثر على إدارتهم للمجلس وبالتالي تحقيقهم لمسئولياتهم. وتثمل هذه البيانات: اسم المدرسة، اسم الإدارة التعليمية، النوع (ذكر أنثى)، المؤهل الدراسي (أقل من بكالوريوس - بكالوريوس أو ليسانس - أعلى من بكالوريوس)، طبيعة العمل في المجلس (رئيس-نائب رئيس- مدير المدرسة- عضو آباء- معلم- عضو (أمناء - أمين سر).

الثاني: عشرة محاور خاصة بمبادئ مدخل لامركزية الإدارة، حيث يتضمن كل محور أسئلة بـ(هل) تكون استجابات أفراد العينة عليها إما (نعم أو لا)، كما تتضمن بعض الأسئلة تكون إجاباتها

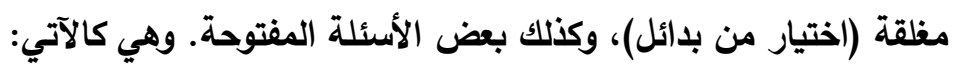

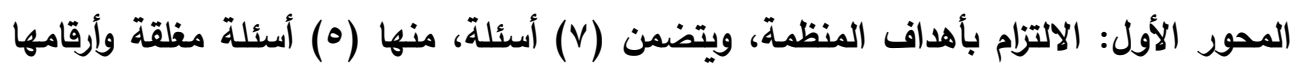

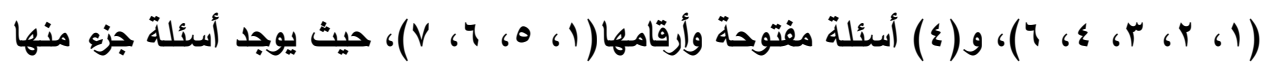

مغلق وجزء مفتوح. 
دراسة إثنوجرافية لمجالس الأمناء والآباء والمعلمين --------- د / هند سيد أحمد

المحور الثاني: مراعاة السياق الثقافي للمجتمع، ويتضمن (^) أسئلة. منها (V) أسئلة مغلقة

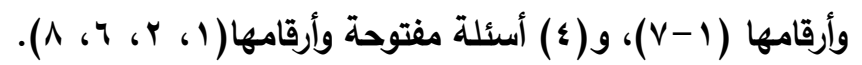

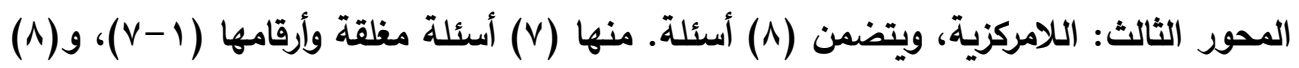
أسئلة مفتوحة وأرقامها (1-1).

المحور الرابع: المشاركة، ويتضمن (^) أسئلة. منها (V) أسئلة مغلقة وأرقامها (V-1)، و(V) (V)

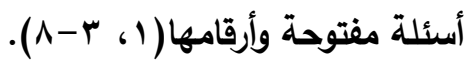

المحور الخامس: العلاقات الإنسانية (وجود رأس المال الاجتماعي)، ويتضمن (9) (9) أسئلة. منها

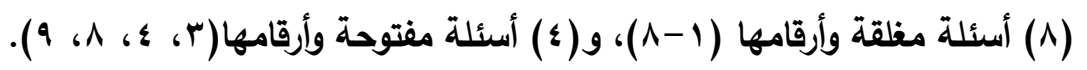

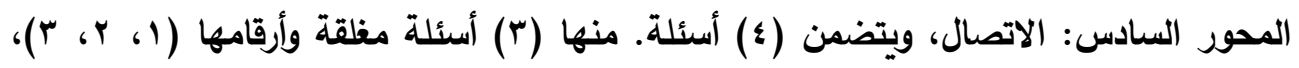
و(r) أسئلة مفتوحة وأرقامها (r ؛ \& ) ).

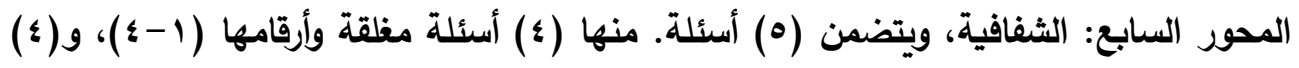

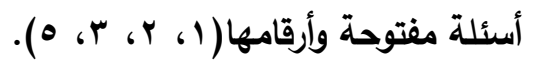
المحور الثامن: التنمية المهنية والتمكين، ويشمل بعدين:

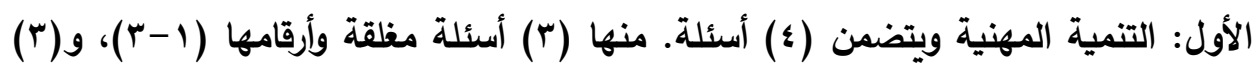

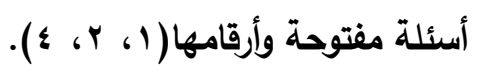

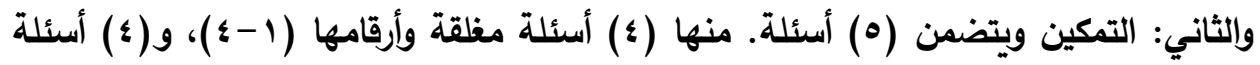
مفتوحة وأرقامها (r - (ه).

المحور التاسع: المحاسبية، ويتضمن (11) سئال. منها (9) أسئلة مغلقة وأرقامها (Y) (1) - (1)،

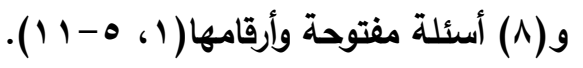

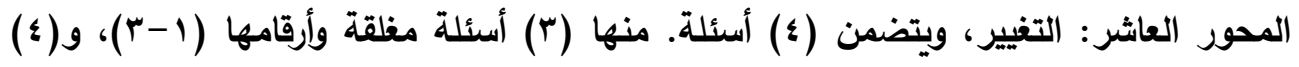
أسئلة مفتوحة وأرقامها (1 - ؛).

ب- صدق وثبات بطاقة المقابلة Validity\& Reliability بالنسبة للصدق الظاهرى (صدق المحكمين) لبطاقة المقابلة؛ تم التأكد منه من خلال عرضها

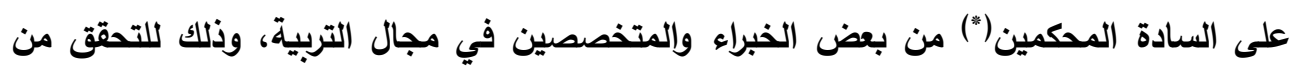




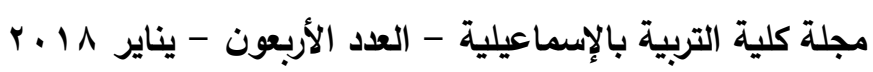

مدى ملاءمة أداة الدراسة للغرض الذي وضعت من أجله، ومدى وضوح الأسئلة وسلامة الصياغة، ومدى كفاية الأسئلة والإضافة إليها والحتف منها. حيث قام المحكمون بإبداء آرائهم في العبارات من حيث مناسبتها للتعريف الإجرائي لكل مبأ من مبادئ مدخل لامركزية الإدارة، وللهاف الذي وضعت من أجله، وكذلك مناسبتها للمحور الذي تندرج فيه. وقد روعي في بناء بطاقة المقابلة الاقة والوضوح، وتجنب استخدام العبارات الغامضة أو غير الواضحة. وفيما يتعلق بالصدق الذاتي الذي يعني صدق الدرجات التجريبية للاختبار بالنسبة للارجات

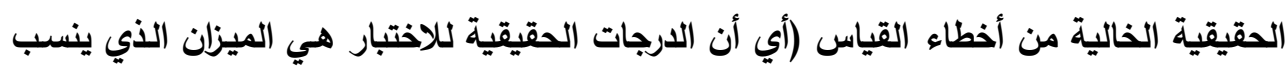
إليه صدق الاختبار)؛ فيقاس عن طريق حساب الجذر التربيعي لمعامل ثبات الاختبار (مصطفى باهي، 9999 19، •)وذلك كما يأتي: الصدقي) الناتي = معامل الثبات

وتم حسابه بعد إيجاد معامل الثبات لبطاقة المقابلة للتأكد من ثباتها كما يأتي:

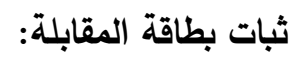
للتأكد من ثبات أداة الدراسة (بطاقة المقابلة) قامت الباحثة بإجراء مقابلة مـع عينة تجريبية مكونة من (^) أفراد من أعضاء مجالس الأمناء والآباء والمعلمين، وبعد مضي ثلاثة أسابيع تم إعادة تطبيق البطاقة على نفس الأفراد في ظروف مشابهة للمرة الأولى قدر الإمكان، وتم حساب ولباء

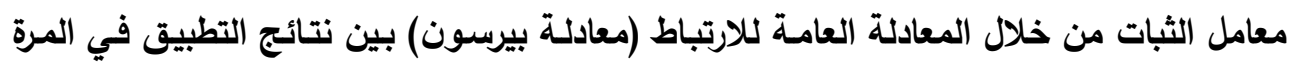

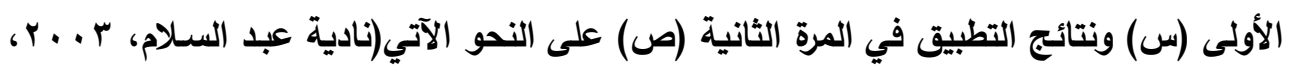

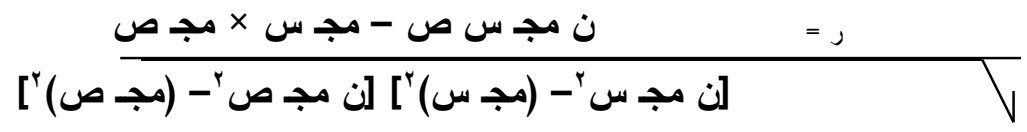

حيث ن= عدد أفراد العينة س= درجات العينة في التطبيق الأول ص= صرجات العينة في

التطبيق الثاني

وقد تم التوصل إلى ثبات بطاقة المقابلة؛ والذي يوضحه قيمة معامل الارتباط لأداة الدراسة (بطاقة المقابلة) وفقاً للمعادلة السابقة؛ حيث وصل الثبات الكلي للبطاقة إلى (هو (9 •))، وهي قيمة عالية تدل على أن بطاقة المقابلة تتميز بقيمة ثبات مقبولة علمياً، وبالتالي القدرة على تطبيقها في أي وقت. 
دراسة إثنوجرافية لمجالس الأمناء والآباء والمعلمين --------- د / هند سيد أحمد

$$
\text { أها الصدق الذاتي = }
$$

وهي نسبة مقبولة إلى حد كبير وتدل على صدق بطاقة المقابلة.

ثالثاً: إجراءات تطبيق الدراسة الإثنوجرافية:

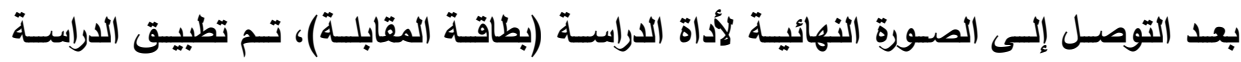

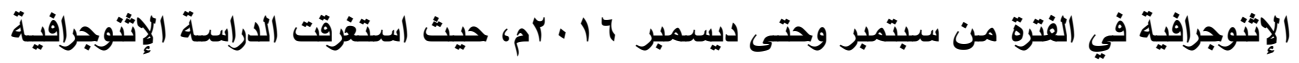
أربعة أشهر؛ وذلك لأن طبيعة المنهج الإثنوجرافي الذي استخدمته الدراسـة يعتمد على الملاحظة

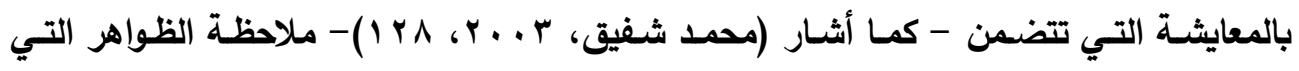
تحدث تلقائياً في ظروف طبيعيـة دون إخضـاعها للضبط العلمي، بـدون استخدام أدوات دقيقـة لقياس الظاهرة موضوع الدراسة ويطلق عليها أيضا الملاحظة غير الموجهة Non-Controlled Observation وتقتضـي الملاحظة المشـاركة أن يثـارك الباحث في الفعل الاجتمـاعي الذني يسعى إلى وصفه وفهمه، ويغلب عليها الطابع الكيفي، وتتضمن اندماج الباحثة في حياة من تقوم

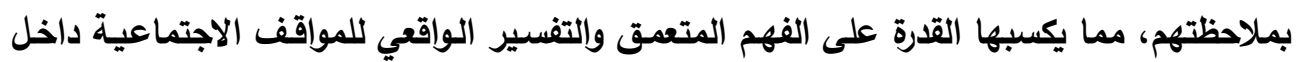

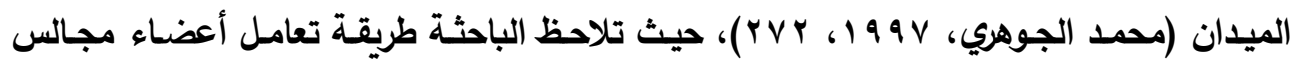
الأمنـاء والآبـاء والمعلمين ببعض المدارس، وذلك أثناء تطبيق أداة الدراسـة (بطاقـة المقابلـة)، وأثناء حضور الباحثة لبعض اجتماعات هذه المجالس. واعتمدت الدراسة على التكرارات، والنسب المئوية لتعرف درجة موافقة أفراد العينة على أسئلة المحاور المختلفة. وبعد عرض إجراءات الدراسة الإثنوجرافية، والخطوات التي اتُبِت في بناء أداة

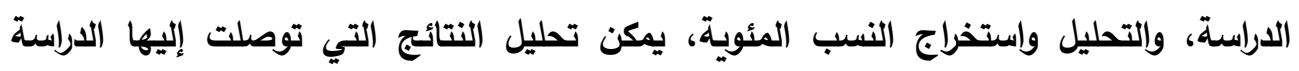
الإثنوجرافية من خلال الآتي:

رابعاً: نتائج الدراسة الإثنوجرافية (واقع مجالس الأمناء والآباء والمعلمين بمحافظة المنوفية) تم تناول نتائج الملاحظة والمقابلة حول واقع توافر مبادئ مدخل لامركزية الإدارة بمجالس الأمناء والآباء والمعلمين التي تم التوصل إليها من خلال المقابلات الثخصية التي تم إجراءها ها مع أعضاء هذه المجالس، بالإضافة إلى نتائج ملاحظات الباحثة أثناء إجراء المقابلات وذلك من خلال عرض واقع إدارة مجالس الأمناء والآباء والمعلمين، من خلال أسلوب التحليل البيئي SWOT Analysis 


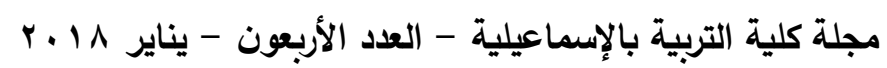

الإداري لهذه المجالس والذي يمثل البيئة الداخلية، كما يعرض الفرص والتهديدات التي تفرضها عليه البيئة الخارجية أو المجتمع المحيط، وهذا من خلال ما توصلت إليه الدراسة الإثنوجرافية عن طريق المقابلات الشخصية، والملاحظة بالمعايشة؛ وذلك من أجل وضع مجموعة من البدائل

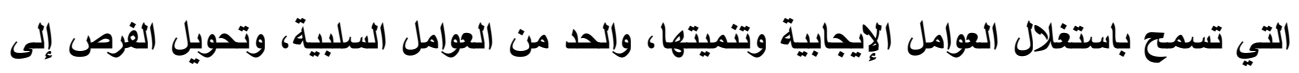
نقاط قوة يمكن استغلالها، والتفلب على التهايدات الخارجية. وهذا ما يتضح من مصفوفة التحليل البيئي الموضحة في الجدول الآتي:

جدول رقم (ॅ)

SWOT مصفوفة التحليل البيئي

\begin{tabular}{|c|c|c|}
\hline مواطن ضعف (Y) (W) & 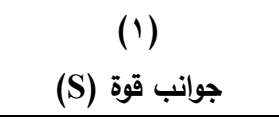 & البيئة الخارجية البيئة الدا \\
\hline (WO) تقليل - زيادة (W) (V) & (0) زلباديل الأول (SO) زيادة & $\begin{array}{c}\text { الفرص (O) } \\
\text { (O) }\end{array}$ \\
\hline (^)البديل الرابع (WT) & (ب) زلبديل الثاني (ST) & $\begin{array}{c}\text { التهايدات (T) } \\
\text { (T) }\end{array}$ \\
\hline
\end{tabular}

والاراسة تستخدم المصفوفة السابقة لتحديد واقع مجالس الأمناء والآباء والمعلمين؛ من خلال الخطوات الأربع الأول وهي: الأولى تحديد جوانب القوة Strengths، وإلثانية تحديد مواطن الضعف Weaknesses، والثالثة تحديد الفرص Opportunities، والرابعة تحديد التحديات Threats أ- الجوانب الإيجابية/ القوة في الأسلوب الإداري لمجلس الأمناء والآباء والمعلمين: توجد مجموعة من نقاط القوة التي يتميز بها الأسلوب الإداري لمجلس الأمناء والآباء الإداء الإباء والمعلمين، ومنها: • القدرة على حل المشكلات التربوية ومواجهتها داخل المؤسسة التعليمية بسهولة ويسر وفي أسرع وقت.

• المشاركة في اتخاذ القرارات الحازمة لحل كافة المشكلات وإزالتها، وتنفيذ هذه القرارات. • فصل الطلاب غير الملتزمين بالحضور أو مثيري الثغب بالفصول. • حربة المناقشة.

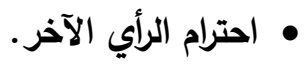


دراسة إثنوجرافية لمجالس الأمناء والآباء والمعلمين --------- د / هند سيد أحمد

• • الاعتماد على جدول الأعمال الذي ينفذ قدر الإمكان.

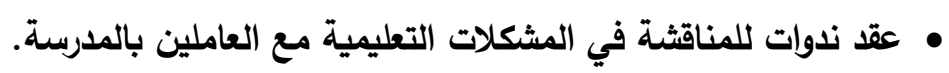

• توفير الموارد المالية من خلال الجهود الذاتية والمشاركة المجتمعية.

• استخدام الهاتف النقال لاتصال أعضاء المجلس ببعضهم البعض مما ييسر من إتمام المهام.

• كلما كان المجلس قويا؛ كانت جهوده ملموسة.

ب- الجوانب السلبية/ الضعف في الأسلوب الإداري لمجلس الأمناء والآباء والمعلمين: توجد مجموعة من نقاط الضعف التي يعاني منها الأسلوب الإداري لمجالس الأمناء والآباء

والمعلمين، وهي:

• ندرة اطلاع الأعضاء على أهداف المجلس من خلال القرار الوزاري والاعتماد فقط على السماع من الأخصائي أو رئيس المجلس.

• ضعف تحقيق جميع أهداف مجلس الأمناء والآباء والمعلمين المحدة بالقرار الوزاري رقم

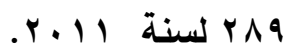

• ندرة التزام الأعضاء بحضور اجتماعات المجلس.

• ندرة التزام أعضاء المجلس بالمواعيد المحددة للاجتماعات.

• ق قلة إيمان بعض أعضاء المجلس بجلية المجلس وأهميته.

• اختيار موعد غير مناسب لاجتماعات المجلس.

• ضعف جدية بعض المجالس وشكليتها، بندرة عقد اجتماعات لها.

• إكمال سجل المجلس والحضور بصورة شكلية غير متكافئة مع الواقع. بون.

• انخفاض قيمة تحمل المسئولية، حيث لا يتحمل أغلب الأعضاء نتيجة أخطائهم.

• انخفاض قيمة الصبر والإقناع عندما تتعارض وجهات نظر الأعضاء مع بعضهم البعض.

• انخفاض مشاركة بعض الأعضاء في إدارة شئون المجلس.

• استئثار بعض مديري المدارس باتخاذ قرارات المجلس.

• استئثار الأخصائي الاجتماعي بوضع خطة المجلس (المدونة شكلياً في سجل المجلس) دون

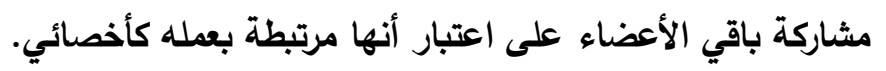

• اعتبار بعض المدارس أن مجلس الأمناء صورة شكلية ولا ترجع إليه في اتخاذ القرارات.

• ندرة عرض مشكلات المدارس على مجلس الأمناء على مستوى الإدارة التعليمية. 


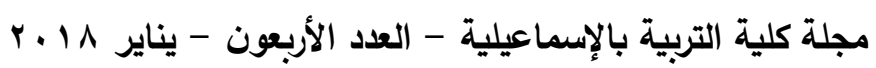
• قلة دراية بعض الأعضاء بوجود مجلس أمناء على مستوى الإدارة والمديرية التعليمية. • اختلاف الانتماءات السياسية فيما بين مجموعات من الأعضاء؛ مما قـ يؤدي إلى قلة الارتياح النفسي، ويقلل من وضوح الأمور ويقلل من التعاون والتواصل فيما بينهم؛ مما يعوق تحقيق أهداف المجلس. • الصراع بين بعض الأعضاء والصوت المرتفع أثناء المناقشة. • انخفاض التعاون والترابط فيما بين بعض الأهراء ولهون الأعضاء.

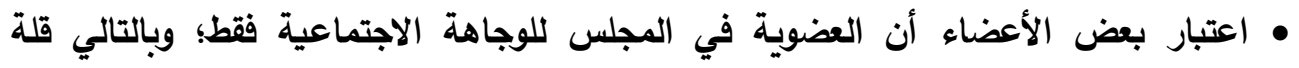
السعي للارتقاء بالمجلس.

• انخفاض رضا بعض الأعضاء عن بعضهم البعض وعن المجلس ككل. • ندرة استغلال العضوية في النقابات أو الجمعيات الأهلية في تعزيز التعاون بين المدرسة والمجتمع. • قلة تنظيم المجلس لأنثطة تخدم المجتمع المحلي للانثغال بالأمور التعليمية. • ضعف استخدام بعض وسائل التكنولوجيا الحديثة مثل المواقع الإلكترونية في الاتصال بأعضاء المجلس أو بأفراد المجتمع الخارجي؛ مما يعوق تكوين علاقات اجتماعية إيجابية.

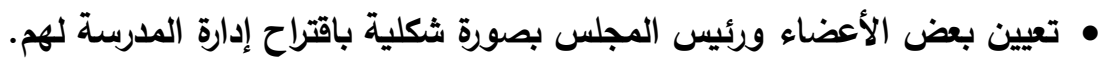

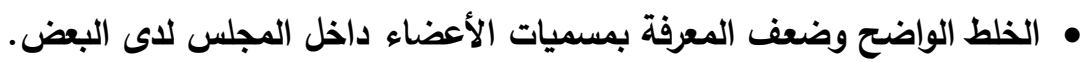
• ندرة التحاق الأعضاء بدورات تدريبية في مجال الإدارة، وندرة تحديدهم لاحتياجاتهم التدريبية في مجال الإدارة؛ لاعتقادهم بأنهم ليسوا في حاجة إلى مثل هذه الدورات. • الحاجة إلى تدريب أعضاء المجلس على مهارات حل المشكلات، واتخاذ القرار، وإدارة الوقت. لإدها. • ندرة توافر مراجع لاى الأعضاء لتنمية قدراتهم الإدارية. • انخفاض القدرة على ابتكار حلول للمشكلات التعليمية في حالة قلة أو انعدام الموارد. • قلة استغلال الأعضاء للقدرة على عرض وتحليل مثكلة أو قضية تعليمية أو اجتماعية من خلال ندوة للطلاب. • انخفاض الوعي بالقواعد المنظمة للمجلس. • لا تضع مجالس الأمناء آليات لزيادة وتحسين جواتب القوة في أسلوبهم الإداري، أو آليات للتغلب على جوانب الضعف بها. 
دراسة إثنوجرافية لمجالس الأمناء والآباء والمعلمين --------- د / هند سيد أحمد

• جمود فكر بعض الأعضاء دون محاولة إجراء تغيير لتحسين الأوضاع للأفضل.

ج- الفرص المتاحة أمام مجالس الأمناء والآباء والمعلمين:

توجد مجموعة من الفرص التي يمكن أن تستغلها مجالس الأمناء والآباء والمعلمين حتى

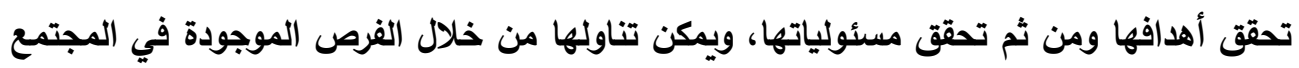

عامةً، والفرص الموجودة في النظام التعليمي خاصة:

- - الفرص الموجودة في المجتمع والتي تساعد المجلس على تحقيق أهدافهـ:

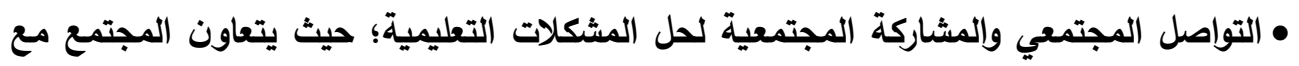
المدرسة من خلال أولياء الأمور، وبعض أعضاء المجتمع المدني، ورجال الأعمال الذين يساعدون المدرسة بما تحتاجه من خلال:

تقديم التبرعات والههبات، والمساعدة في دفع مصروفات بعض الطلاب غير القادرين، وتبرع صاحب مصنع الطوب بكمية منه للمدرسة، ومشاركة رجال الدين في حل بعض المشكلات المدرسية، ومساعدة أصحاب المهن والخبرات لتذليل الصعوبات التي تعوق حل المشكلات. • تأجير بعض أفراد المجتمع لفناء المدرسة بمقابل مادي يمثل زيادة لموارد المدرسة تستخدم لصالح العملية التعليمية.

• العلاقات الاجتماعية الإيجابية مع بعض أفراد المجتمع -خاصةً - في المؤسسات الخدمية المحيطة مما يفيد العمل التربوي. • التكنولوجيا الحديثة من أجهزة حاسب وإنترنت. - الفرص التي يقدمها النظام التعليمي (المدرسة /الإدارة التعليمية/ المديرية/ الوزارة) والتي تساعد المجلس على تحقيق أهدافه: • بالنسبة للمدرسة: تعاون المعلمين والإدارة المدرسية مع المجلس. • المدرسة تتيح الفرصة لعقد اجتماعات مجلس الأمناء؛ حيث يتوافر بها المكان للاجتماع بأعضاء المجلس. • بعض المدارس هي مدارس فصل واحد وعدد طلابها صغير؛ وبالتالي مشكلاتها قليلة. • بض المدارس حديثة الإنشاء فتتسم بقلة المشكلات في البنية الأساسية لها. • المدرسة تفيد في تقديم الخدمة التعليمية التي تمثل أحد أهداف المجلس. • الإدارة التعليمية: تتميز أحياناً بالمرونة في اتخاذ القرار. $r \leq T$ 
مجلة كلية التربية بالإسماعيلية - العدد الأربعون - يناير 1^ ب r • الإدارة التعليمية توفر دورات تدريبية للأخصائيين الاجتماعيين ولبعض أعضاء مجلس الأمناء، ومن خلال هذه الدورات تزبد الخبرات مما يؤدي إلى تفعيل المجلس. • الإدارة التعليمية تعاون مجلس الأمناء والآباء والمعلمين وتساعده في تحقيق أهدافه من خلال الموافقات التي تعطيها على بعض أنشطته.

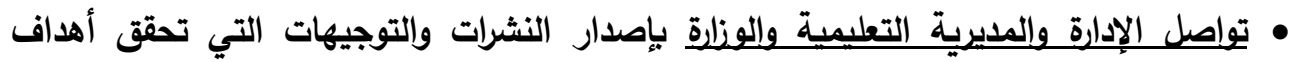
المجلس.

• الوزارة تقدم دورات في بعض الأحيان عن اللامركزية وجودة التعليم مما يساعد أعضاء المجلس من المعلمين والمديرين المشاركين فيها.

د- التهـيدات المحتملة:

يوجد عدد من التهديدات التي تواجه مجالس الأمناء والآباء والمعلمين، ويمكن تناولها من خلال التحديات التي يفرضها المجتمع عامةً، والتحديات التي يفرضها النظام التعليمي خاصة الامناء - التحديات التي يفرضها المجتمع على المجلس والتي تعوقه عن تحقيق أهدافه: • الجمود وقلة الاتصال بالمدرسة. • قلة الإمكانات المتاحة، وقلة تقديم المساعدات. • استهتار بعض أفراد المجتمع بما يطلبه منهم مجلس الأمناء.

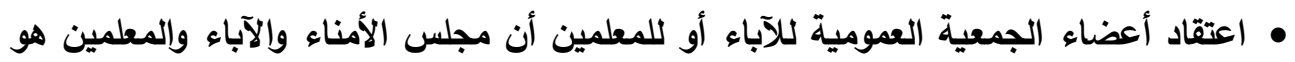
وسيلة لجمع المال، واعتقادهم أن حضورهم لا يؤثر على المدرسة ولا على المجلس، وأن المجلس سيتم تثكيله في كل الأحوال. • من الممكن أن يكون هناك أعضاء جيدين بالمجتمع وأولياء أمور جيدين كان من الممكن أن يستفيد منهم المجلس، ولكن نتيجة ندرة حضورهم الجمعية العمومية فلم تتعرف إليهم المدرسة، وبالتالي تخسر المدرسة عضويتهم في المجلس. - - التحديات التي يفرضها النظام التعليمي على المجلس والتي تعوقه عن تحقيق أهدافه: • توحيد ميزانية جميع المجالس بالمدارس على مستوى الإدارات التعليمية مما يعوق الصرف لفري وإتمام تنفيذ الأنشطة. • بالنسبة للمدرسة والإدارة التعليمية: ندرة توافر الإمكانات، ومثكلة الأثاث والحاجة إلى الصيانة. 
دراسة إثنوجرافية لمجالس الأمناء والآباء والمعلمين --------- د / هند سيد أحمد

• البيروقراطية والروتين الذي يتمثل في الجمود في تنفيذ القواعد أو اللوائح، والتعسف والرفض

والتعقيد؛ عندما يطلب المجلس بناء فصول لحل مشكلة الكثافة بالفصول.

• حاجة بعض المدارس الثانوية إلى فصل الثانوي التجاري عن الثانوي العام كلٍ في مدارس باء لهول مستقلة، بسبب المشكلات التي قد يسببها الثانوي التجاري للعام.

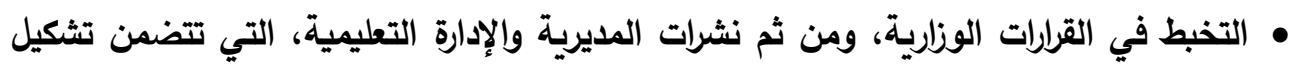

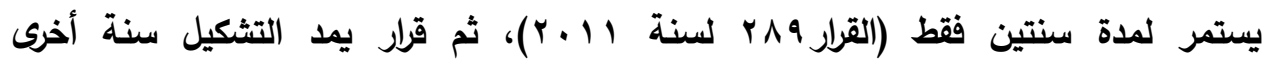

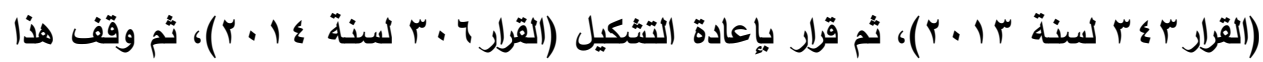

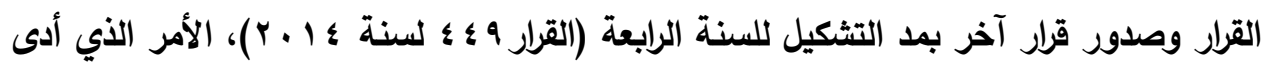
إلى ضياع مصداقية المجلس لاى أولياء الأمور وأفراد المجتمع الخارجي. ومن هنا فإن هذا الجزء الميداني يكون قد عرض نتائج معايثة الباحثة وتطبيق بطاقة المقابلة

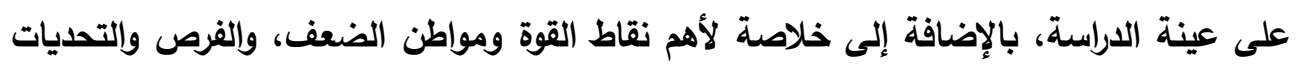
لإدارة مجالس الأمناء والآباء والمعلمين بالمدارس. وفي الجزء التالي يقدم البحث بدائل وآليات مقترحة لتطوير إدارة هذه المجالس وفقاً لمدخل لامركزية الإدارة، وذلك لزيادة كفاءة إدارة هذه المجالس بما يؤدي إلى تحقيق مسئولياتها. المحور الرابع: بدائل وآليات مقترحة لتطوير إدارة مجالس الأمناء والآباء والمعلمين في ضوء مدخل لامركزيـة الإدارة يعرض الجزء الحالي أهم نتائج الدراسة النظرية والإثنوجرافية، كما يعرض البدائل المقترحة لتطوير إدارة هذه المجالس، والآليات المقترحة لتطوير إدارة مجالس الأمناء والآباء والمعلمين،

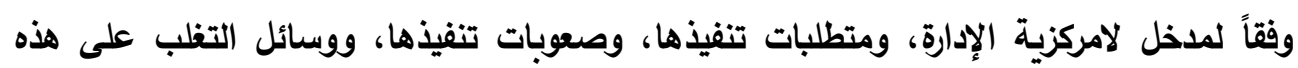
الصعوبات. وذلك على النحو الآتي: أولاً: أهم نتائج الدراسة النظريـة والإثنوجرافية: وداته 1- أثارت الدراسة التحليلية النظرية إلى وجود مجموعة من المسئوليات التي تقع على عاتق مجالس الأمناء والآباء والمعلمين. r- توصلت الدراسة من خلال الأدبيات، وبعض الاراسات السابقة إلى وجود مجموعة من المعوقات التي تحول دون تحقيق هذه المسئوليات، ومعظم هذه المعوقات معوقات إدارية. 


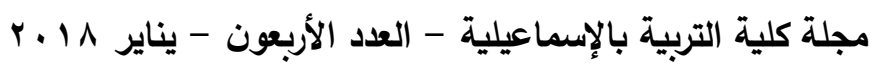

r- بيَّتت الاراسة التحليلية النظرية أن مدخل لامركزية الإدارة هو السبيل للتغلب على هذه باله

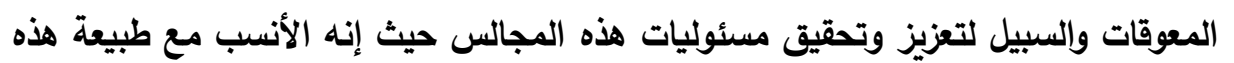
التنظيمات التي تتسم بقدر من الاستقلالية.

؛ - توصلت الاراسة الإثنوجرافية إلى وجود جوانب قصور وضعف في الأسلوب الإداري لهذه

المجالس مما يعوق قيامها بمسئولياتها.

ثانيا: بدائل مقترحة لتطوير مجالس الأمناء والآباء والمعلمين وفي ضوء ما توصل إليه البحث من مسح للبيئة الداخلية التي تتضمن نقاط القوة والضعف بمجالس الأمناء والآباء والمعلمين، والبيئة الخارجية التي تتضمن الفرص والتهديدات التي تؤثر

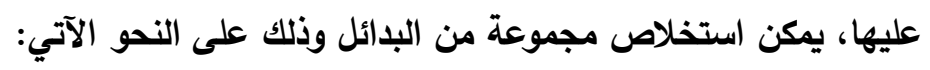
في ضوء مصفوفة التحليل البيئي لمجالس الأمناء والآباء والمعلمين كما يوضحه الملحق الآئ رقئ (ع)؛ توصلت الدراسة إلى أربعة بدائل لتطوير إدارة هذه المجالس، وهي: البديل الأول (SO) زيادة- زيادة:

يتضمن هذا البديل الاهتمام بجواتب القوة وتقويتها حتى يمكن استغلال الفرص الاصديل المتاحة أمام المجلس، ويمكن تحقيقه من خلال الآليات الآتية: • توسيع نطاق الندوات المنعقدة لتشمل العناصر الفعالة من أولياء الأمور، ورجال الأعمال، وأعضاء المجتمع المدني، ورجال الدين، وأصحاب المهن. • تكوين العلاقات الاجتماعية الإيجابية مع هؤلاء الأفراد سواء بالزيارات المباشرة أو من خلال

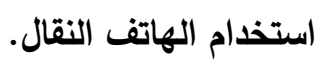

• إتاحة الفرصة لهؤلاء الأفراد لإبداء آرائهح بحرية تامة. • احترام آرائهم تقديراً لمشاركتهم المادية أو المعنوية وتعزيزاً لها. • تنظيم هذه الندوات من خلال إعداد جدول أعمال. • استغلال تعاون المعلمين مع المجلس من خلال دعوة بعضهم لاجتماع المجلس لعرض المشكلات التي تواجههم، والإفادة من اقتراحاتهم لحلها.

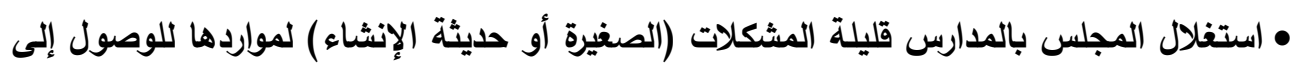
الاعتماد. 
دراسة إثنوجرافية لمجالس الأمناء والآباء والمعلمين --------- د / هند سيد أحمد

• استفلال الخبرات المستفادة من الدورات التدريبية في تحقيق المجلس لمسئوليته؛ من خلال نقلها لباقي الأعضاء وحل المشكلات التعليمية. • التقويم الأتي بتحديد مواضع القوة والضعف بالمجلس. • الاهتمام بوضع آليات لزيادة وتحسين جوانب القوة لدى المجلس. البديل الثاني (ST) زيادة - تقليل:

يركز هذا البديل على استغلال نقاط القوة الموجودة بالمجلس للتظلب على وتحجيم التهديدات

وإلتحديات التي تواجهة، وذلك من خلال الآليات الآتية: • توسيع نطاق الندوات المنعقدة لتشمل العناصر الفعالة من أولياء الأمور، ورجال الأعمال، وأعضاء المجتمع المدني، ورجال الدين، وأصحاب المهن.

• توعية هؤلاء الأفراد بأهمية أدوارهم وحضورهم ومشاركتهم للنهوض باهئ العملية التعليمية.

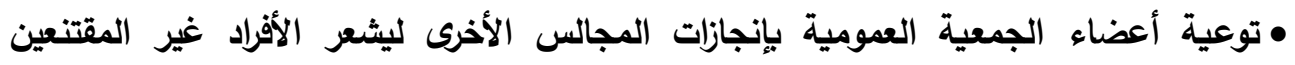
بالمجلس بأهميته، وذلك عن طريق حرية المناقشة وإنشاء موقع إلكتروني لمجالس الأمناء والآباء والمعلمين. • استثمار واستغلال المتوفر من الإمكانات الاستغلال الأمثل ووفقاً لأولويات المدرسة للتغلب على قلة الإمكانات. • الاتصال بالمؤسسات الخدمية المحيطة مثل الوحدة المحلية، أو شبكة الكهرباء التلبية احتياجات المدرسة من أعمال صيانة أو نظافة. • التزام المجلس بتنفيذ ما يطلب منه عن طريق وضع خطة زمنية، وتحديد الهذف منها، وتحديد القائمين على التنفيذ، وأساليب تقويم ومتابعة ومحاسبة القائمين على التنفيذ.

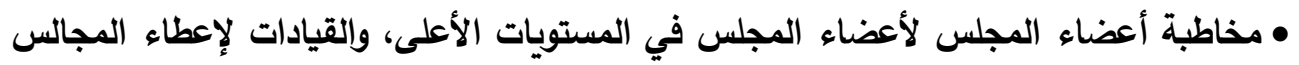

مزيداً من المرونة لتيسير الصرف من ميزانية المجلس حتى يمكن إتمام الأنشطة المقترحة.

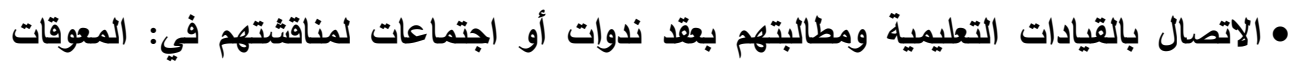
الإدارية التي تواجه المجلس وتعوقه عن تنفيذ الأنشطة التي يقترحها، ومحاولة وضع حلول

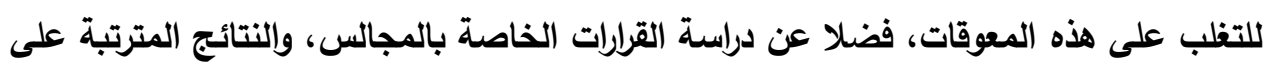
اتخاذ هذه القرارات. البديل الثالث (WO) تقليل - زيادة: ro. 
مجلة كلية التربية بالإسماعيلية - العدد الأربعون - يناير 1^ ب r

يتضمن هذا البديل محاولة تقليل نقاط الضعف الموجودة بالمجلس، واستغلال الفرص المتاحة لتقليل النتائج المترتبة على نقاط الضعف حتى يمكن للمجلس تحقيق أهدافه؛ ويمكن تنفيذ هذا البديل من خلال الآليات الآتية: • الإفادة من الاورات التدريبية المنعقدة من خلال تضمين شرح وافي لأهداف مجلس الأمناء والآباء والمعلمين وتوضيحها، وتوزيع نسخة من القرار الوزاري على جميع الأعضاء. • استغلال التكنولوجيا الحديثة بإنشاء موقع خاص بمجالس الأمناء والآباء والمعلمين يتضمن الاعن أهداف هذه المجالس وتثكيلها، والقواعد المنظمة لها؛ لتوعية الأعضاء والمهتمين بالعملية التعليمية بهذه المجالس وأهميتها لتعظيم الإفادة منها. • نشر تجارب وخبرات مجالس الأمناء الناجحة من خلال هذا الموقع الإكتروني أو الاورات التدريبية للإفادة منها في التغلب على المشكلات والمعوقات التي تواجه المجالس الأخرى. • تعظيم الإفادة من مشاركة أفراد المجتمع عن طريق تفعيل اجتماعات المجلس وذلك من خلال: الاهتمام بعقد اجتماعات المجلس. والتزام الأعضاء بالحضور، والالتزام بالمواعيد المحددة لبداية ونهاية الاجتماعات. وتطبيق النشرات والقرارات الوزارية التي تستوجب عزل الأعضاء الذين يتغيبون عن حضور الاجتماع ثلاث مرات بدون عذر، وتحديد مواعيد مناسبة لحضور الاجتماع، وإخطار الأعضاء مسبقاً بموعد الاجتماع. • الإفادة من الدورات التدريبية في تنمية روح التطوع، وإعلاء الضمير الذاتي، وتحمل المسئولية لاى الأعضاء؛ مما يساعد على تحقيق مسئوليات المجلس وتحقيق أهدافه. • عقد ورش عمل تساعد على التدريب على الحوار، وتقبل الرأي الآخر، والصبر، ومحاولة الإقناع؛ وذلك بمساعدة خبراء الموارد البشرية. • عقد ورش عمل تساعد على التدريب على التعاون، والمشاركة، وتوزيع الأدوار. • توسيع نطاق الدورات المنعقدة لتشمل جميع الأعضاء. • الإفادة من مجالس الأمناء في المستويات الأعلى بعرض المشكلات المتعثرة أو المعوقات التي تواجه المجلس عليها. • تغليب المصلحة العامة على المصالح الثخصية للتظلب على اختلاف الانتماءات السياسية،

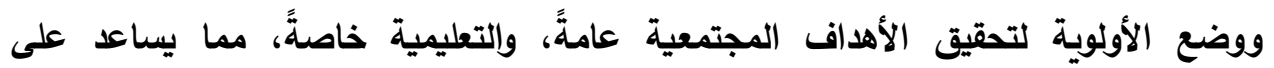
الاستغلال الأمثل لمشاركة أفراد المجتمع، ويعزز التعاون والتواصل. 
دراسة إثنوجرافية لمجالس الأمناء والآباء والمعلمين --------- د / هند سيد أحمد

• استغلال العضوية في النقابات أو الجمعيات الأهلية في تعزيز التعاون بين المدرسة والمجتمع سواء من خلال تعزيز مشاركتهم المادية أو ابتكار أنشطة تتم بالتعاون فيما بينهم. • الالتزام بتعيين الأعضاء بالانتخاب حتى تتوافر روح الحب والود فيما بينهم وبالتالي يقلل من الصراع والتناحر -خاصةً - أثناء النقاثشات.

• استغلال قررة بعض الأعضاء على عرض وتحليل مشكلة أو قضية تعليمية أو اجتماعية من خلال ندوات للطلاب. • الاهتمام بوضع آليات للتظلب على جوانب الضعف بالمجلس. • تضمين بعض المفاهيم في الدورات المنعقدة مثل الإيمان بالتغيير، والمبادرة بالإصلاح. البديل الرابع (WT) تقليل - تقليل: هذا البديل يحاول التغلب على نقاط الضعف الموجودة بالمجلس وعلاجها، مع محاولة التغلب على التهديدات المحتملة، ويشمل الآليات الآتية: • توعية أولياء الأمور بالحضور في الجمعية العمومية، حتى يمكن انتخاب أعضاء المجلس ولتهل بصورة مناسبة.

• عقد اجتماع الجمعية العمومية لأولياء الأمور، وعقد احتفال بأوائل الطلاب لتقديم جوائز لهم

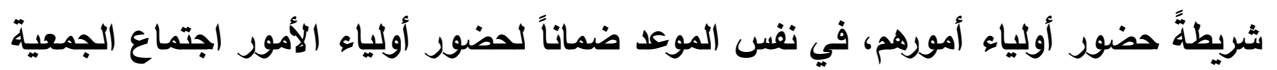

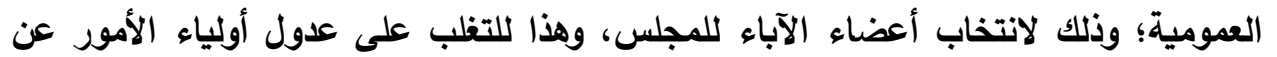
حضور اجتماع الجمعية العمومية الأي يؤثر على انتخاب المجلس. •حسن اختيار أعضاء المجلس بحيث يكونون على دراية بالعمل الاجتماعي، والتعليمي، أو يكوية يكونون رجال أعمال.

• استغلال العضوية في النقابات أو الجمعيات الأهلية في تعزيز التعاون بين المدرسة والمجتمع سواء من خلال تعزيز مشاركتهم المادية أو ابتكار أنثطة تتم بالتعاون فيما بينهم.

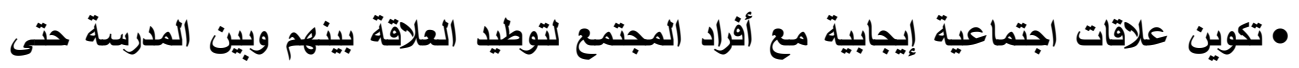
يمكن استغلالها لتحقيق أهداف المجلس. • تفعيل هذه المجالس وبالتالي تحسين صورتها أمام غير المقتنعين بها، وذلك من خلال: الاطلاع على القرار المنظم لعمل المجلس، وتجنب الخلافات فيما بين الأعضاء، ومحاولة التعاون فيما بينهم، وضرورة أن يكون هناك عزل للعضو غير الفعال، ووضع أولويات لتفيذ 


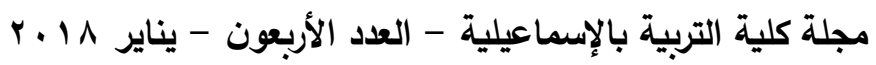
الخطة كما يراها المجلس للتغلب على قلة الإمكانات، والالتزام بتعيين الأعضاء بالانتخاب حتى

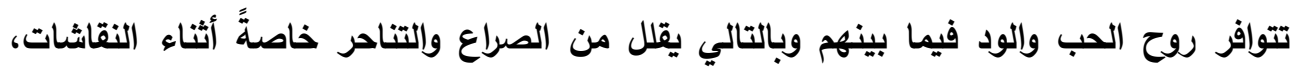
والاهتمام بتنفيذ أنشطة تخدم المجتمع. • محاولة ابتكار وسائل جديدة لزيادة إمكانات وموارد المجل، وذلك بتفعيل اجتماعات المجلس

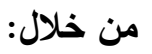

الاهتمام بعقد اجتماعات المجلس. والتزام الأعضاء بالحضور، والالتزام بالمواعيد المحددة لبداية ونهاية الاجتماعات، وتطبيق النشرات والقرارات الوزارية التي تستوجب عزل الأعضاء الذين يتغيبون عن حضور الاجتماع ثلاث مرات بدون عذر، وتحديد مواعيد مناسبة لحضور الاجتماع، وإخطار الأعضاء مسبقاً بموعد الاجتماع. • تعميم الدورات التدربية في مجال الإدارة لتشمل أعضاء مجالس الأمناء والآباء والمعلمين وجميع القيادات التعليمية، وتفعيل هذه الدورات على أرض الواقع للتفلب على الروتين والبيروقراطية والمركزية التي تعوق المجلس عن تنفيذ أنشطته. • أن تتضمن هذه الاورات التدريب على مهارات حل المشكلات ومهارات اتخاذ القرار؛ حتى تكون قرارات إيجابية ومناسبة ومتزنة وتراعي المصلحة العامة. • إجراء أعضاء المجلس لاراسة ذاتية تتضمن تحديد جوانب القوة، والضعف بالمجلس، والفرص والتهايدات التي يفرضها المجتمع الخارجي، وذلك لتحسين أوضاع المجلس والتغيير للأفضل. ثالثًا: آليات مقترحة لتطوير إدارة مجالس الأمناء والآباء والمعلمين (البديل (الخامس) إن تطبيق مدخل لامركزية الإدارة بمجالس الأمناء والآباء والمعلمين يشير إلى مشاركة أعضاء مجالس الأمناء في تيسير شئونهم ذاتياً في جميع الوظائف الإدارية من تخطيط، وتنظيم وتنسيق، وتنفيذ، وتوجيه، ومتابعة ورقابة، وتقويم؛ في ضوء إمكانات المجلس وموارده وظروفه على نحو مستقل، على أن تتم هذه المشاركة (في هذه الوظائف الإدارية) في إطار من العلاقات الاجتماعية الإنسانية الإيجابية فيما بين أعضاء المجلس، في ظل التعاون والثقة، والتماسك والاندماج، والالتزام بالقيم والمعايير الاجتماعية. وهذا أيضاً في إطار من التعاون والتكامل والتثارك مع تنظيمات المجتمع. وهذا ما يبين الفلسفة الاجتماعية للعملية التعليمية. 
دراسة إثنوجرافية لمجالس الأمناء والآباء والمعلمين --------- د / هند سيد أحمد

وفي هذا الإطار يمكن تناول آليات كل من العمليات أو الوظائف الآتية: (التخطيط، والتنظيم والتنسيق، والتتفيذ، والتوجيه، والمتابعة والرقابة، والتقويم) على النحو الآتي:

Planning آليات التخطيط،

التخطيط وظيفة إدارية تهتم بتوقع المستقبل وتحديد أفضل السبل لإنجاز أهداف المؤسسة. ويتضمن إجراء تغييرات مقصودة تتم بواسطة الاستخدام الأمثل واللواعي للإمكانات والموارد المادية والبثرية والتنظيمية ومن الضروري أن يكون واقعياً على أساس المتاح من هذه الموارد، وأن يكون شاملاً ومتكاملاً لمختلف الأنثطة ومن خلال تضافر الجهود الحكومية والذاتية، وأن يكون

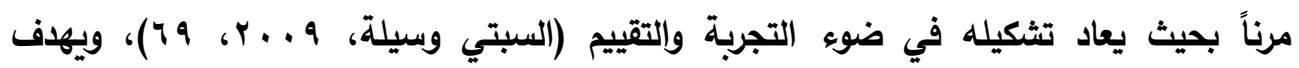
التخطيط إلى تحقيق التميز أي القدرة على إنجاز نتائج غير مسبوقة يتفوق بها الفرد على نفسه وعلى الآخرين وأن يتحاشى قدر الإمكان التعرض للخطأ، وتتمثل آليات التخطيط التي يقوم بها مجالس الأمناء بالمدارس في الإجراءات الآتية: أ- تحديد فلسفة المجلس، ورسم السياسة العامة للمجلس، وتحديد القيم التي يعتمد عليها، وتحديد أهدافه بوضوح، ومن ثم وضع خطة سنوية محدد بها الأهداف والأنثطة للعام التالي. كما تتضمن الخطة تحديد احتياجات ومثكلات المدرسة ومواردها وأولوياتها، حيث يتم محاسبة المجلس في ضوء هذه الخطة أمام الوزارة والمجتمع بثكل عام. وهذا ما أكده بانج ) (Pang, 2006, 13) فبالنسبة لموارد المجلس والتي تعبر عن مصادر قوته، فمن الضروري تحديدها سواء كانت بثرية أو مادية؛ حتى يتم تحديد الأنثطة التي يمكن للمجلس أن يقوم بها. وعلى المجلس أن يحسن من هذه الموارد من خلال تحليل التغذية الراجعة والتي تحدد أيضاً المهارات والمعارف المتطلب إكسابها للموارد البثرية. ب- تصميم فريق العمل (أعضاء المجلس)، على أن تتناسق قيمهم مع قيم المجلس والمدرسة ككل، وخاصةً تنمية قيم الانتماء للمجتمع الصغير (المدرسة) والمجتمع الكبير بصفة عامة، وتحمل مسئولية تطويره، وتعريفهم بمسئوليات المجلس ككل، وتخصيص المهام والمسئوليات على أعضاء المجلس، وإيجاد نظم لتتبع أداء فريق العمل، على أن يتم السماح لأعضاء المجلس بتحديد أهداف العمل بأنفسهم في ضوء الأهداف العامة، وأن تكون أدوار ومسئوليات أعضاء المجلس واضحة؛ ويفهم كل عضو ما هو المتوقع منه، بالإضافة إلى له توضيح كل من الأهداف والهيكل التظظيمي للعاملين. 


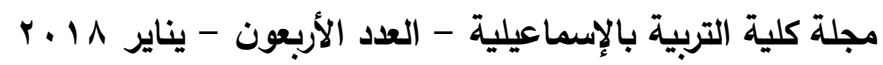

ج- التخطيط يتطلب وضوح الرؤية والفهم السليم، ودراسة احتياجات الطلاب التعليمية واحتياجات كل من المدرسة والمجتمع بثكل عام ومشكلاتهم؛ وذلك من خلال القراءة

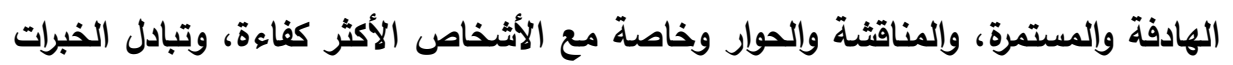

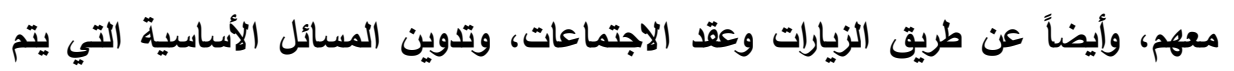
بحثها في الاجتماعات، والقرارات التي اتخذت، والمشكلات التي اكتشفت ولم يتم حلها وذلك ولكارت

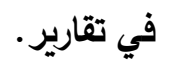

د- يتطلب التخطيط استخدام المعلومات والبيانات لفهم المثكلات وتقويم العلول، الأمر الذي يتطلب توفير كافة المعلومات من خلال وجود قاعدة بيانات متجددة، وإعداد كتيبات إرشادية، وتوفير النشرات الدورية؛ على أن تشمل هذه المعلومات -كما يثير (ضياء الدين)- معالم التطوير والتحسين المستمرين التي يقوم بها المجلس، وما تم إنجازه، والتشريعات المنظمة للعمل المدرسي وقواعد الانضباط المعمول بها داخل المدرسة (ضياء

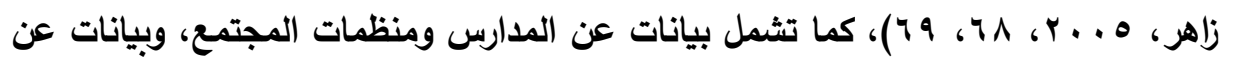
العاملين بالمدرسة ومعرفة الأعداد وحصر العجز والزيادة، وبيانات عن الطلاب. كما تثمل

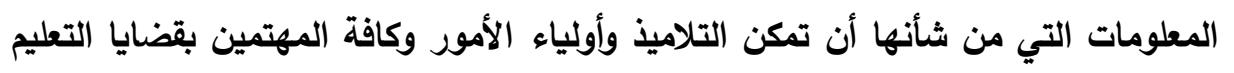
في المجتمع المحلي من المشاركة الفعالة في صناعة القرارات المدرسية، وبما يتيح لأعضاء المجلس الحرية والمرونة في اتخاذ القرارات وفق أسس وقواعد ثابتة ووفق الظروف المحيطة بها، وحث الآباء على النهوض بدورهم المنشود في مجالس الآباء والمعلمين،

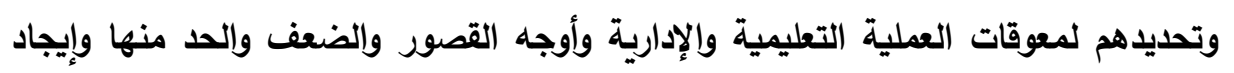

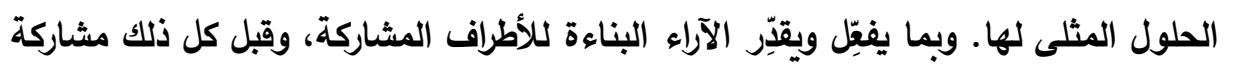
جميع الأطراف في تجميع ووضع هذه المعلومات. هـ - يتطلب الأمر السماح بتداول هذه المعلومات من خلال (الهاتف- الفاكس- البريد الالكتروني) فيما بين أعضاء المجلس، ومن ثم تحليلها ووضعها في تقارير ـ ومن الضروري

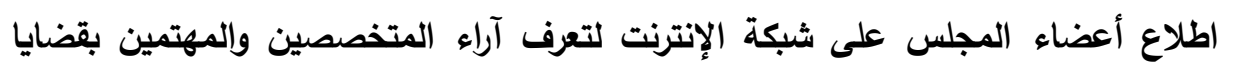
التعليم المختلفة ولتعرف نتائج أبحاثهم وكذلك الاطلاع على ما انتهت إليه المؤتمرات المعنية بالمسائل التربوية والتعليمية المختلفة. وعقد مقارنة بين البيانات السابقة والحالية والمتوقعة. وهذا ما أكدته دراسة (نجوى المسيري، و و . . r ). 
دراسة إثنوجرافية لمجالس الأمناء والآباء والمعلمين --------- د / هند سيد أحمد

و - بالنسبة للتخطيط للتفويض فيتطلب التفويض الناجح تحديد المهام المطلوبة، واختيار الثخص المناسب للتفويض إليه، وبيان حدود الرقابة، ومراعاة تعادل السلطة والمسئولية. ويتطلب أيضا تحديد المحدات والضوابط التي يجب الالتزام بها عند التنفيذ للثخص الأي تم التفوبض إليه، ويتم ترك مساحة مناسبة له ليفكر بنفسه، وتتاح لله فرص الإبداع الثخصي والتعبير عن ذاته وإمكاناته، وكذلك منحه فرصة للتدريب العملي. ز - بالنسبة للتمويل فيتطلب تدبير موارد إضافية لتنفيذ الخطة والأنشطة التي تتضمنها ولتمويل المدرسة. وتزوبد المدارس بكل ما تحتاجه من خدمات وربطها بالبيئة المحيطة بها. وتعزيز

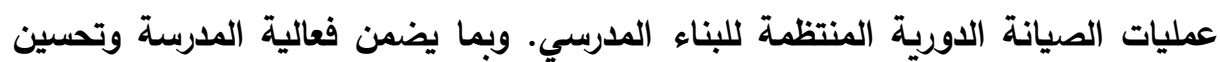

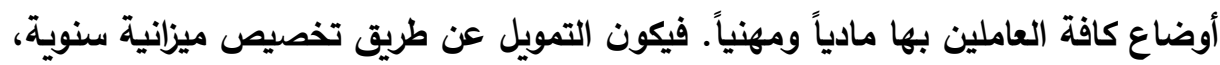
ويكون التمويل ذاتي مقابل الخدمات التي تقدمها المدرسة للمجتمع، أو مساهمة من مؤسسات المجتمع. فهو قـ يكون من خلال الحكومة بالإضافة إلى المصروفات الدراسية. وتقديم منح دراسية للتلاميذ المتفوقين وتقديم معونات مالية من المدرسة لأولياء الأمور.

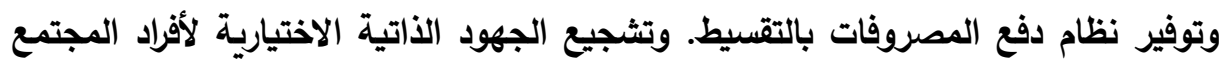
ومؤسساته. التبرع ببناء مدارس جديدة تضمن تخفيف كثافة الفصول، وتحد من تعدد الفترات الدراسية. والمساهمة في منح المدرسة التمويل الكافي لإتاحة الفرص للإبداع والابتكار. تحديد بنود صرف الميزانية. وتحول المدرسة إلى وحدة إنتاجية لتكون مصدراً للاخل.

Organizing\& Coordinating آليات التظظيم والتنسيق

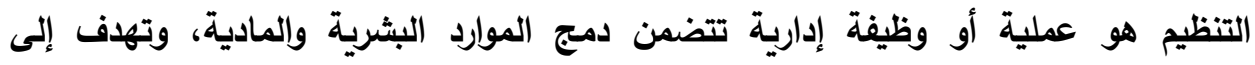
مساعدة الأعضاء على العمل بكفاءة وفي انسجام بما يساعد على تنفيذ المهام لتحقيق الأهداف بكفاءة وفاعلية. ويشمل تحديد المهام والأعمال المطلوب القيام بها، وتحديد المسئولين عن تنفيذها والسلطات الممنوحة لهم. أي يتضمن توصيف العمل؛ فيتم فيه تنظيم الجها والتوجه نحو الهدف. أ- وفقاً لمدخل لامركزية الإدارة من الضروري أن يتم التنسيق بين المدارس المختلفة، وتنسيق الجهود بين وزارة التربية والتعليم، والجهود الحكومية والمحلية الأخرى، ونقابات المعلمين. وذلك على سبيل المثال للاتفاق على أسس توزيع المعلمين على المدارس بما يقضي على 
مجلة كلية التربية بالإسماعيلية - العدد الأربعون - يناير 1^ ب r

العجز والزيادة. وهذا التنسيق يتم من خلال جهود أعضاء مجالس الأمناء والآباء والمعلمين؛ التي تسعى إلى تكوين علاقات جيدة والقيام بمبادرات لمقابلة أفراد هذه الجهات المختلفة والمتخصصين من ذوي الخبرات لجذب مشاركتهم في تقديم بعض الخدمات والأنثطة وحل المشكلات التعليمية والنهوض بالتعليم. ب- توطيد الاتصال بين المدرسة والمجتمع يتم عن طريق أمور عديدة منها: إعداد البرامج

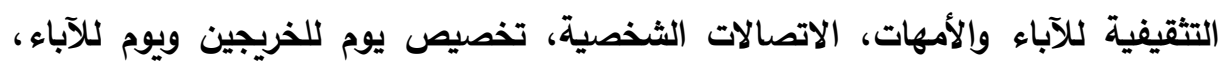

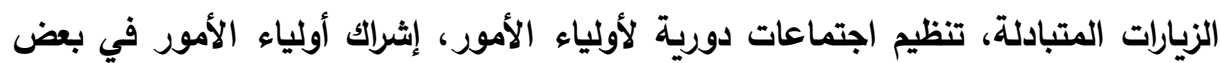
الأعمال المدرسية مثل: الإشراف على الاراسات المسائية، وتنظيم نقل الطلاب في الرحلات. وإنشاء قاعدة بيانات تربوية تتضمن نماذج للمشاركة المجتمعية. وهذا ما أكدته دراسة

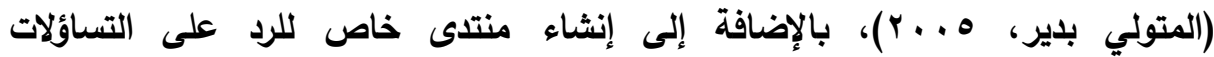

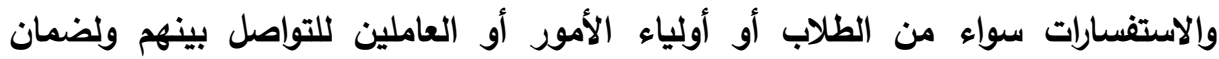

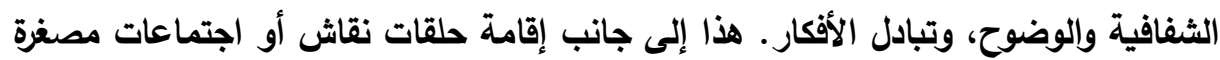

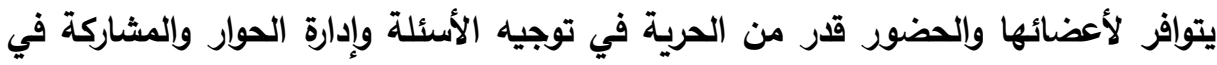
صنع القرار . ج- من آليات التظيم والتنسيق العمل على ترسيخ ثقافة المشاركة والعمل ضمن فريق بين أعضاء مجالس الأمناء والآباء والمعلمين وأيضاً كافة مؤسسات المجتمع المحلي المحيط،

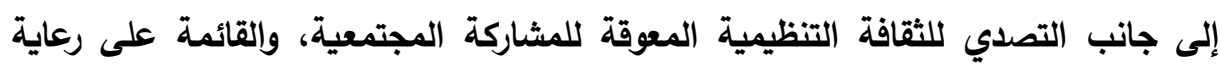
المصالح الاتية. وهذا ما أكدته دراسة (محمد العجمي، ه . . ب). حيث إنه من خلال المشاركة تتضافر الجهود والإمكانات والموارد والأفكار والخبرات وتبادل المعلومات فيما بين أعضاء مجلس الأمناء، وفيما بين أفراد المجتمع، بما يسمح بتيسير شئونهم، وبما يسمح

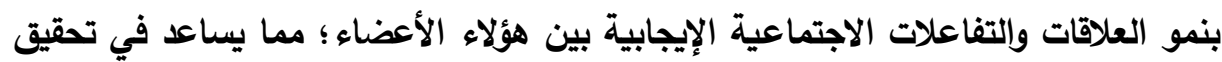

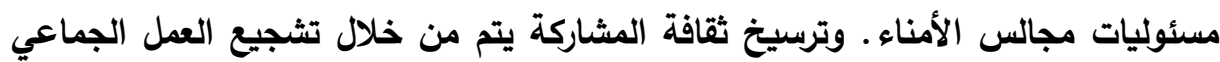
وتنمية العلاقات وإزالة المعوقات الاتصالية بين الأعضاء، إلى جانب إثراء وتنمية الوعي مني

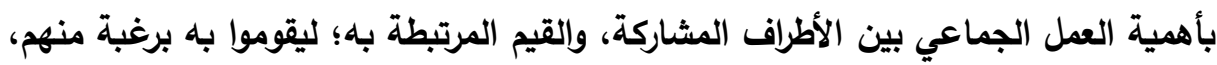
وخلق الثعور بأهمية جماعية القيادة فيما بين الأعضاء. وحثهم على المشاركة في جميع الوظائف الإدارية التي يقوم بها المجلس. 
د- المشاركة تكون إما بالرأي أو جمع المعلومات أو الدراسة أو النقاش في كل جزئية في العمل المشترك والتي تحتاج إلى قرار. مع محاولة تشجيع الأعضاء على تقديم آرائهم في صورة جاته مكتوبة، والتي تساعدهم على تنظيم أفكارهم وصياغتها في شكل منطقي، ومحاولة إيجاد علاقات منطقية بين المعلومات المتاحة، وهو ما يثيع مناخاً عقلانياً في صناعة القرار أولاً ثم تنفيذه. وقد تكون المشاركة من خلال تقديم الدعم المالي للمدرسة، والمشاركة في أنشطة المدرسة. بهدف الإفادة بما يتوافر من موارد وإمكانات في دعم العملية التعليمية. هـ - في إطار تنظيم وتنسيق جهود أعضاء مجالس الأمناء والآباء والمعلمين في ضوء فئ مدخل

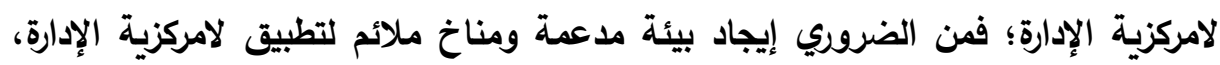
وهذا ما يتم من خلال بناء وتنمية مهارات الأعضاء بما يؤدي إلى تمكينهم، وتمتعهم بالكفاءات المطلوبة، وبحيث تكون هذه المهارات موجهة نحو العمل الجماعي؛ الذي يتضمن احترام جميع الأعضاء لبعضهم البعض ولقائدهم. وبالنسبة لرئيس المجلس عليه أن يكون

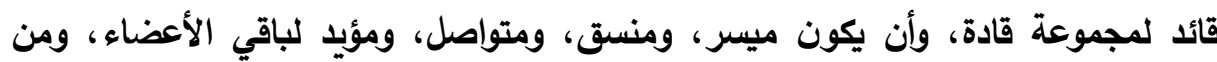

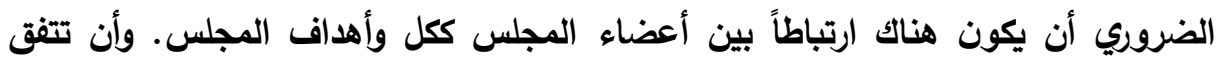

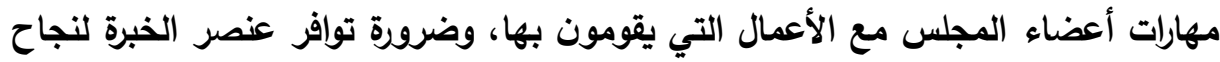
أعضاء المجلس في أداء أدوارهم. و - يتم تنمية هذه المهارات عن طريق تدريب الأعضاء وتأهيلهم لتحمل المسئوليات الجديدة؛ فيتم توفير برامج تدريب منظمة للارتقاء بمهاراتهم ومعارفهم، يقدم من خلالها التدربب

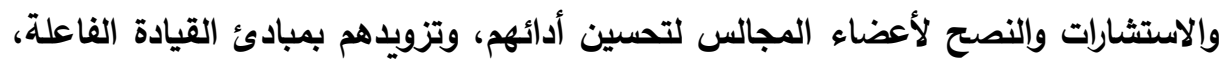
ومساعدتهم على المشاركة في اتخاذ القرار الجماعي واعتبار كل فرد قائداً في مهمته. وتأهيل المتطوعين للمشاركة في مشروعات تجويد الأداء المدرسي، على أن يتم الاستعانة بالخبراء الذين يساعدون على إطلاق القدرات المتنوعة للأعضاء وتفعيل طاقاتهم الكامنة، وإكسابهم مهارات التفكير النقدي، وتدريبهم على العصف الذهني، بالإضافة إلى التدربب على التفاعل والمشاركة فيما بينهم، والعمل بروح الفريق مع وجود الحوار . ز - عقد ندوات وحلقات عمل للتعريف بلامركزية الإدارة وأهدافها، والنتائج الإيجابية لتطبيقها لضمان وصول هذا المفهوم إلى الأعضاء وزيادة حصيلتهم من المهارات والمعارف، وضرورة نشر القيم التظيمية الإيجابية بين الأعضاء من خلال اطلاعهم على كافة 


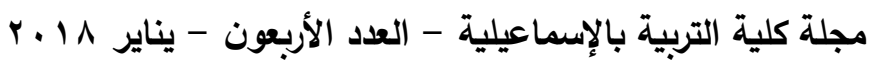

المعلومات فيما يخص الأهداف والخطط مما يعمل على دعم الالتزام بالقيم والتوجهات التي

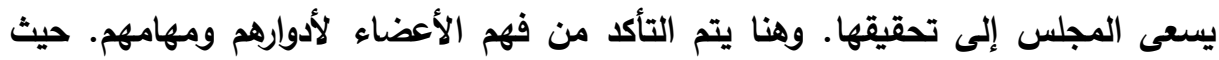
يتطلب الأمر حسن توزيع السلطات والمسئوليات على أعضاء المجلس حتى يشعر كل عضو منهم بأنه مسئول، إلى جانب زيادة مساحة المسئولية والمساءلة، فالمناخ المتحرر المرن؛ يستتبعه بالضرورة تحديد المسئوليات حتى يمكن أن تتم المحاسبة. ح- استكثاف الدوافع المؤدية لتحقيق أعلى مستويات الرضا لاى الأعضاء عن العضوية في لبوني المجلس، وبحث السبل التي تؤدي إلى إثباع هذه الدوافع؛ من خلال تقديم الحوافز المرتبطة

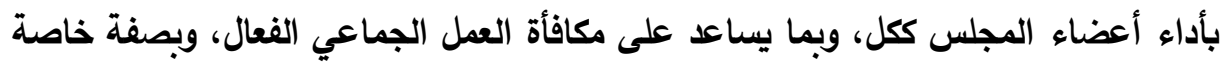
معنوياً لأن هذا العمل يعتمد على التطوعية. ط- الاعتراف بغياب المعرفة بثأن أمر ما، حتى يصبح لاى العضو المزيد من الوقت للبحث

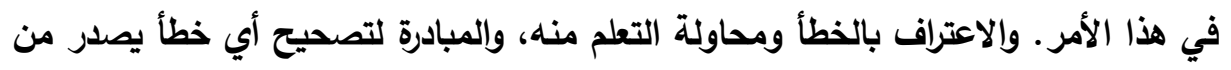
أي عضو من أعضاء المجلس. وضرورة هيمنة الثفافية والوضوح على أساليب العمل.

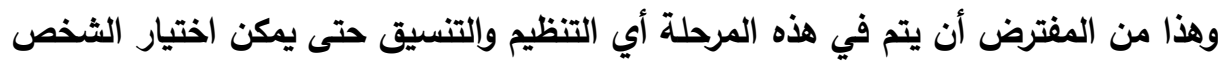
المناسب للمهمة المناسبة. ي - الإدارة بأسلوب الفعل وليس بأسلوب رد الفعل. بالإضافة إلى الدمج والتكامل في الجهود بين المستويات الأفقية والرأسية في نفس الوقت. والتنسيق بين الأدوار. وإزالة الازدواجية في المسئوليات والسلطات فيما بين الأعضاء. وعلى رئيس المجلس الأس أن يقوم بتثجع أعضاء المجلس، وتنظيم الاجتماعات، ووضع جدول أعمال للمجلس. ك- من أهم آليات التظيم والتنسيق لجهود أعضاء مجالس الأمناء والآباء والمعلمين وفقاً لمدخل لامركزية الإدارة عقد الاجتماعات. وهذه الآلية لا تستخدم لهذه الوظيفة الإدارية فقط؛ وإنما يتم من خلال هذه الاجتماعات التخطيط، والتنظيم والتنسيق، والتوجيه، وبعض أعمال المتابعة والرقابة والتقويم. فالاجتماعات فرصة جيدة للتعلم وفرصة لتوجيه الأعضاء ، وإعطاء

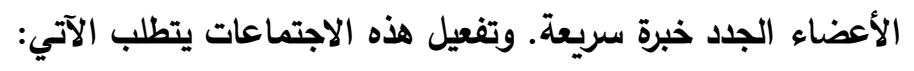
- - مضور الاجتماعات بطريقة دورية وباستمرار. - - أخذ خلفية عن موضوعات الاجتماع قبل حضور الاجتماع من خلال جدول الأعمال المعد مسبقاً. 
دراسة إثنوجرافية لمجالس الأمناء والآباء والمعلمين --------- د / هند سيد أحمد

- - دعوة أفراد من شأنهم المشاركة في حل المشكلات التعليمية وتحقيق مسئوليات المجلس مثل: العاملين بالمدرسة الذين يمتلكون صورة أوضح للاحتياجات والمثكلات التعليميةالخبراء المثقفون الذين يمتلكون الأفكار المبتكرة لحل هذه المشكلات - أفراد مجتمع (رجال

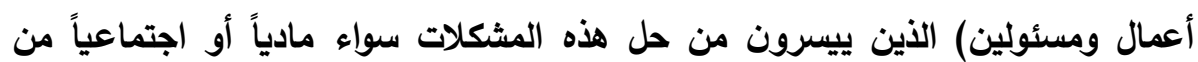
خلال تسهيل الحصول على موافقات لتنفيذ بعض الأنشطة. على أن يكون لايهم اتجاه إيجابي وفعال نحو مسئولية المجلس. - ترحيب أعضاء المجلس وبصفة خاصة مدير المدرسة بهؤلاء الأفراد، وتقديرهم، وذلك لجذب اهتمامهم لتعزيز مسئولية المجلس. - - - طرح الأسئلة والتوضيحات والاقتراحات من قبل الأعضاء أثناء الاجتماع. - - تحفيز رئيس المجلس لأعضائه على توليد الأفكار الجديدة القابلة للتطبيق.

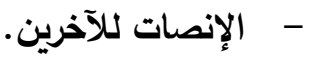
- - الاعتراف بالأخطاء ، وتحمل المسئولية. - - توفير المناخ الذي يسمح بالمناقشة والحوار وإبداء الرأي بطريقة ديمقراطية والمساعدة ولإنة على اتخاذ القرارات المناسبة. - - م- إدارة وقت الاجتماع بثكل مفيد. r-

يمكن تعريف التنفيذ بأنه يتمثل في الأداء الفعلي وممارسة المهام والأنثطة المتفق عليها، سواء أكان ذلك من قِبل أعضاء مجلس الأمناء والآباء والمعلمين أم من قبل الأطراف المشاركة لهذه المجالس (طلاب- معلمين - أولياء أمور - أفراد المجتمع). وهو يعني التحرك من المعرفة إلى العمل، مع تحمل العضو أو الفرد لمسئولية الفعل الذي يقوم به، ومن آليات التنفيذ: أ- تفعيل آليات الممارسة العملية للديمقراطية وذلك بتعزيز ثقة الآباء والمهتمين بالقضايا التعليمية والمجتمعية بمكانة المدرسة؛ عن طريق الترحيب بهم، وإعطائهم الاهتمام الكافي الذي يُشعرهم بأهميتهم وتقدير المدرسة لهم. لهمبه ب- مشاركة جميع الأعضاء والأطراف في اتخاذ القرارات لحل المشكلات المدرسية. ج- تحقيق الثمولية والتكامل فيما بين موضوعات القرارات التي يتم اتخاذها في المجلس. د- تيسير تفعيل القرارات التي تم اتخاذها. rT. 


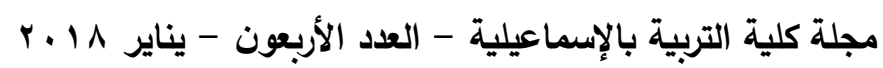
هـ - المبادرة، وأن يبدأ الفرد بالأهم فالمهم.

و - معالجة العادات التي تحبط من الفاعلية في الأداء، مثل التقصير في متابعة الإنجاز. ز - التفكير أثناء التففيذ في تحقيق المنفعة العامة وأن تكون الأولوية لخدمة العملية التعليمية. ح- الاستخدام الأمثل للموارد المتاحة بما يحقق أفضل النتائج. ط- القيام بالأفعال دون انتظار مقابل لذلك؛ لأن عمل هذه المجالس يعتمد على التطوعية. ي - أن تكون النتائج التي سيتم التوصل إليها ذات معنى ومرئية وإذا تيسر الأمر يمكن قياسها. ك- حرية العمل، وتبادل الأدوار. ل - السماح لأعضاء المجلس بتحديد مواعيد بلاية الدراسة. م- ضرورة تمركز القرارات حول التلميذ والمعلم، وذلك بالتركيز على مستوى أداء المعلمين وجودة المخرجات التعليمية (التلاميذ).

ن - قيام الطلاب بالمعكرات الصيفية أو بأنشطة تخدم المجتمع. س -تفعيل دور الطلاب في إدارة الأنشطة الطلابية كالرحلات والمعكرات تحت إثراف المعلمين. ع- الاهتمام بممارسة الأنثطة التي تساعد الطالب على تحمل المسئولية وإدارة المواقف المختلفة.

ف- اختيار المعلمون للمناهج التي يقومون بتدريسها ومدى صلاحيتها لاحتياجات الطلاب ومناسبتها للمرحلة العمرية ووفق ثقافة المجتمع المحلي والقيم التي تتناولها هذه المناهج. ومناقثة الآباء للمناهج التي تم اختيارها؛ مع عرض ما تم مناقثته على المتخصصين

$$
\text { والخبراء في المناهج. }
$$

ص - تكامل الأداء فيما بين أعضاء المجلس والأفراد المشاركين. ق - تنفيذ اللوائح والقواعد الخاصة بتنظيم العمل داخل المدرسة. ر - استخدام أعضاء المجلس حق التعيين والاستغناء عن بعض الأفراد بالمدرسة. ش -التركيز على أهمية الدور القيادي لتيسير وتسهيل أداء الأدوار. ت- تطبيق سياسة المرونة في أداء المهام بما يتوافق مع ظروف المبل المدرسية.

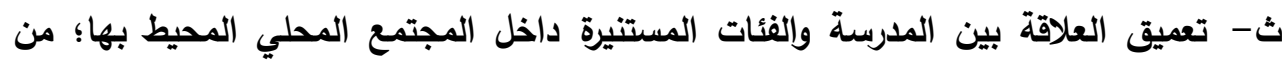
خلال دعوتهم لإلقاء ندوات للطلاب والعاملين بالمدرسة، واستثارتهم في حل المشكلات 
دراسة إثنوجرافية لمجالس الأمناء والآباء والمعلمين --------- د / هند سيد أحمد

خ- تنفيذ وحدة الأمر بحيث لا يكون هناك تضارب في القرارات التي تم اتخاذها.

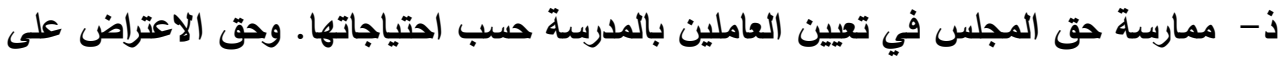
نقل مدرس (بصورة عقابية أو غيرها) طالما يحترم زملاءه ويتواصل معهم، ويلتزم بقواعد بادين العمل السائدة في مدرسته. ومشاركة أولياء الأمور الفعلية في اختيار المعلمين القائمين على التعليم.

ض - منح أولياء الأمور الحق في المشاركة في بحث المشكلات التعليمية بالمدرسة وإبداء الرأي فيها من خلال مجلس الأمناء.

ظ- تفويض بعض الأعضاء أو أي من الأطراف المشاركة للقيام ببعض المسئوليات مع محاسبتهم بما يضمن تحقيق المرونة والحرية والاستقلالية في أداء المجلس.

ـ - آليات التوجيه

التوجيه عملية إدارية يقصد بها إصدار الإرشادات والتعليمات والتوجيهات لإرشاد وتحفيز العاملين على تنفيذ الأعمال حتى تتحقق الأهداف المنشودة، ويهذف التوجيه إلى تصحيح المسار وتجنب الممارسات غير الفعالة في أداء أعضاء المجلس؛ الأمر الأي يزيل من فعالية المجلس. ويتم التوجيه وفقاً لمدخل لامركزية الإدارة من خلال الآليات الآتية: أ- أن يكون التوجيه مبيناً على الإرشاد وليس اصطيهادا للأخطاء. ب- تكوين علاقات جيدة وفعالة بين الأعضاء وبعضهم البعض، وبينهم وبين أفراد المجتمع الخارجي. فهذه العلاقات تسهل من فهم الأعضاء لبعضهم البعض؛ مما يتيح إفادتهم من إمكاناتهم وطاقاتهم في تحقيق مسئولياتهم. وتنظيم هذه العلاقات يحتاج إلى ما يسمى بإدارة الثئون الاجتماعية التي تتطلب الآتي: - مراعاة حقوق ومشاعر الأعضاء لبعضهم البعض وليلأفراد المشاركين في تنفيذ أنشطة المجلس. - - أن تقوم هذه العلاقات على التعاون والاحترام. - - احترام القانون والقيم الأخلاقية. - - الحفاظ على العلاقات الإيجابية مع قادة المجتمع وحائزي القوة الاجتماعية والمؤسسات

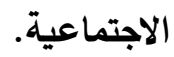
- - تغليب المصلحة الجماعية ومصلحة العملية التعليمية على المصالح الفردية. 


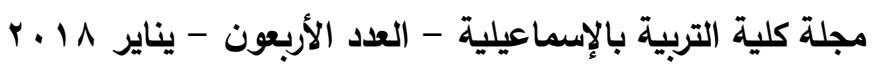
ج- أن يراعي المساواة والثفافية والتسامح مع الجميع؛ وتكوين العلاقات الاجتماعية الإيجابية القائمة على القيم الإيجابية.

د- ولأن مدخل لامركزية الإدارة يعتمد على مشاركة جميع الأعضاء في الإدارة والتوجيه فمن الإنه

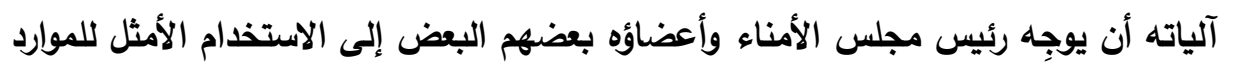
المتاحة؛ إضافةً إلى توجيه وإرشاد بعضهم البعض إلى إلى استكشاف أي موارد غير ظاهرة

$$
\text { ويمكن استغلالها. }
$$

هـ - إعادة توجيه الموارد لتتناسب مع الأهداف المرجوة في المدرسة ومع الميزانية المخصصة لنشاط أو مجال معين.

و - مساعدة رئيس المجلس للأعضاء على التفكير الذاتي واتخاذ القرارات بتثجيعهم عند ظهور أي مبادرة أو فكرة مبتكرة من أي منهم.

ز - تنظيم مشاركة الأعضاء في إدارة شئون المجلس أو في تنفيذ المهام المتفق عليها. ح- تعزيز رئيس المجلس للأعضاء عند قيامهم بسلوكيات تحقق مسئوليات المجلس. ط- وضع برامج تعزيز ومنح حوافز(بصفة خاصة المعنوية) لأعضاء المجلس أو أيّ من المشاركين لتحثهم على أداء العمل بكفاءة وفعالية وتشعرهم بأهمية دورهم وتجعلهم أكثر إيجابية ومسئولية عن النتائج. ي - أن يتم التعزيز ومنح المكافآت والامتيازات للعناصر الجيدة فقط من أعضاء المجلس أو أيٍّ من المشاركين؛ حيث إن المساواة في المكافآت ليست دائماً حافزاً جيداً للعمل. ك- أن يثكر العضو الآخرين ويعترف بجهودهم وأفكارهم، وتقديرهم حيث يؤدي التشجيع إلى تفجير أفضل ما لاى الأفراد من طاقات كامنة. ل - إكساب الأعضاء ثقتهم بأنفسه وفي بعضهم البعض، وتعزيز قيم العمل الجماعي لديهم حتى يقومون بمسئولياتهم بفاعلية.

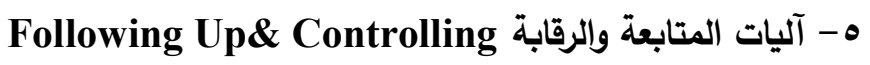
يمكن تعريف المتابعة والرقابة على أنهما عمليتان إداريتان مرتبطتان يقصد بهما الإثراف على الإنى تنفيذ الأنشطة والمهام التي تم التخطيط والتنظيم لها، وتتطلب الاتصال الدائم بمجالات العمل والتأكد من أن الأعمال تسير كما خُطط لها وتحقق الأهداف المتفق عليها. وتتم المتابعة والرقابة

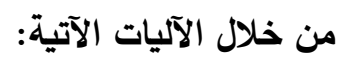


دراسة إثنوجرافية لمجالس الأمناء والآباء والمعلمين --------- د / هند سيد أحمد

أ- التحديد الدقيق لنظام الإشراف، واستخدام اللجان للاراسة؛ بما يسمح بمشاركة ودمج وتفعيل

جهود جميع أعضاء المجلس في عملية المتابعة والرقابة.

ب- أن تكون عملية المتابعة والرقابة داخلية من قبل رئيس المجلس وأعضائه أو خارجية من

قبل أفراد المجتمع أو الإدارة المحلية أو الإدارة والمديرية التعليمية.

ج- متابعة تحديد أولويات تنفيذ الأنشطة.

د ـاكتشاف الأخطاء، وتحديد المسئولين عنها، واتخاذ الإجراءات لتصحيحها.

هـ - إزالة المعوقات التي تعترض التنفيذ، وحل المشكلات المحتمل حدوثها.

و - فهم جوانب قوة ومواطن ضعف أعضاء المجلس واستخدام جوانب قوتهم لإنجاز المهام كفريق.

ز - المصارحة بحقائق الصراع والخلافات لتيسير سلوك التعاون والحفاظ على تحرك المجموعة

نحو أهدافها.

ح- إعداد ودراسة التقارير الدورية عن الخدمات والأنشطة المنفذة والتي تحدد مدى التقدم في

إنجازها.

ط-الثفافية وإتاحة نشر التقارير للأعضاء، والعاملين بالمدرسة، وللمهتمين بالعملية التعليمية. ي - الإثراف على ومراجعة الميزانية. ك- أن تكون عملية المتابعة مستمرة.

ل- تحديد حجم مشاركة الأعضاء في تخطيط وتنظيم وتنفيذ أنشطة المجلس.

م- تحديد مستوى المشاركة والحضور في اجتماعات المجلس، والذي يدل على مستوى فعالية ومشاركة الأعضاء في صنع توجهات المجلس ومن ثم المدرسة.

ن- متابعة مدى التغيير ومعدلاته في عضوية المجالس مما يدل على إتاحة الفرصة لتداول القيادة أمام أكبر عدد من الأفراد؛ وبما يفسح المجال للمبتكرين.

צvaluation آليات التقويم

يمكن تعريف التقويم بأنه عملية إدارية يقصد بها تحديد مدى النجاح أو الفشل في تحقيق الأهداف المتفق عليها، ومعرفة الإيجابيات والاستمرار فيها، والسلبيات وحلها أو الابتعاد عنها؛

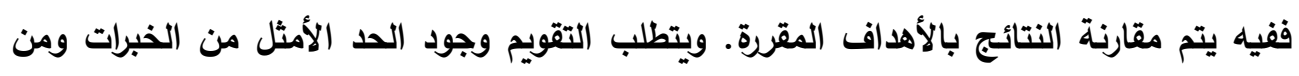
البيانات الحديثة. وتتمثل آلياته في الآتي: 


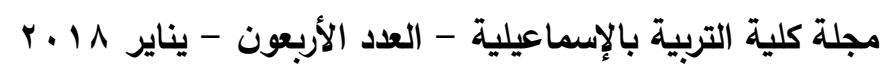
أ- وضع معايير لتقييم الأنشطة والنتائج التي تم التخطيط لها؛ وتثتق هذه المعايير من الأهداف التي تم الاتفاق عليها مسبقاً. ب- دراسة طبيعة العمليات التي يتم بواسطتها تحقيق الأهداف. ج- تحديد مصادر التمويل التي تم الاستعانة بها. د-تحديد مدى مراعاة التوقيت الزمني المحدد لتفيذ النشاط والمحدد بالخطة. هـ - تحديد حجم وأعداد المستفيدين من تنفيذ كل نشاط. و - تحديد معدل كفاءة القائمين بالعمل بالنسبة للمسئوليات المختلفة. ز - تحديد المعوقات والاحتياجات التي واجهت الأعضاء أثناء تنفيذ الأنثطة. ح- أن يتم التقويم بطريقة منظمة وموضوعية. ط-أن يكون التقويم شامل لجميع الأنشطة التي تم التخطيط لها، وأن يكون شامل لكل أعضاء المجلس والأفراد المشاركين في تنفيذ الأنشطة. ي - أن يكون التقويم على المستوى الفردي والجماعي؛ أي يكون التقويم لأداء كل عضو على الآنى حده، وللمجلس ككل، وللمدرسة بصورة أكبر.

ك- أن يكون التقويم مستمر وبصورة منتظمة؛ بحيث يتم قياس الأداء أثناء تنفيذ النشاط، وفي

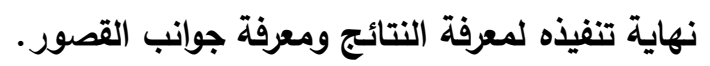
ل - تحديد العوامل المؤثرة على أداء أعضاء المجلس في ضوء البيئة المحيطة.

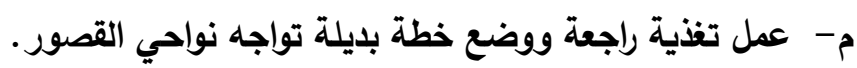
ن- بناءً على نتائج التقويم يتم الإعداد لتيسير سبل تعزيز وتطوير العلاقات بين المدرسة والمجتمع المحلي.

س - إبداء التوصيات اللازمة لتحسين سير العمل واللازمة لإعداد خطط جديدة. ع- الكثف عن حقيقة التأثير الناتج عن تنفيذ نشاط ما. ف- الكثف عن حقيقة التغيير الاجتماعي والمعنوي الناتج عن تنفيذ نشاط ما. ص- إجراء المجلس عملية تقويم للمدرسة التي يشرف عليها؛ من حيث تحديد الاحتياجات التعليمية والتدريبية للمدرسة والعاملين بها، وتحديد وسائل التغلب عليها لتحسين الأداء

$$
\text { المدرسي. }
$$
ق - تحديد مستوى التلاميذ (التحصيل الدراسي) بالمدرسة التي يشرف عليها المجل. 
دراسة إثنوجرافية لمجالس الأمناء والآباء والمعلمين ---------_ د / هند سيد أحمد

ر - تحديد مدى المشاركة في صناعة قرارات تحسين وتجويد المنظومة التعليمية بالمدرسة. س -إعداد التقارير النهائية. ت- أخذ آراء المستفيدين والمهتمين بالعملية التعليمية (طلاب- أولياء أمور - أفراد المجتمع)

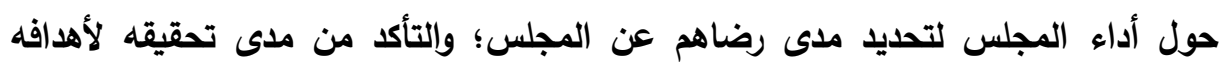

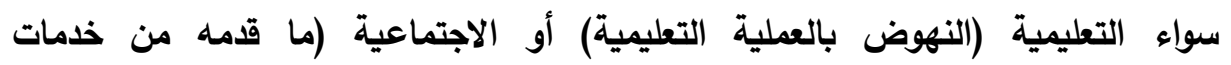
للمجتمع). ومن ثم تحديد احتياجات ومتطلبات النهوض بأداء المجلس وتحقيقه لمسئولياته؛

$$
\text { وبالتالي ترتيب أولويات علاج هذه الاحتياجات. }
$$

ث - مقارنة معدلات الأداء عبر فترات زمنية مختلفة، أو بأداء المجالس بمدارس أخرى بهدف التحسين المستمر لأدائها مما يشجع المبادرات الفردية والجماعية والتتافسية للمجلس.

خ- أن يقوم أعضاء المجلس بعمل تقويم ذاتي حيث يُقَّوم كل عضو نفسه وأفعاله. بالإضافة إلى عمل تقويم ذاتي لمدى تحقيق المجلس لمسئولياته (إنجازات المجلس)، وتقويم ذاتي لأداء أعضاء المجلس ككل (الأسلوب الإداري للمجل)؛ بحيث يشمل هذا التقويم تحديد لنقاط القوة والضعف داخل المجلس، والفرص والتهديدات التي تفرضها البيئة الخارجية للمجلس. وبالتالي يحدد المجلس مدى نجاح عمل أعضائه بثكل جماعي، ومن ثم يصبح المجلس في عملية تعلم مستمر وتطوير تنظيمي دائم يزيد من فعاليته.

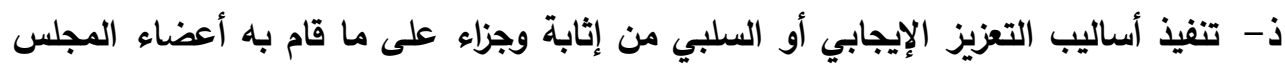

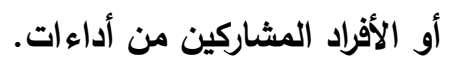
ض- - أن تتم تغييرات في أداء المجل،، وطريقة تنفيذ الأنشطة بناءً على نتائج عملية التقويم.

وترى الدراسة أن هذه الوظائف أو العمليات الإدارية الستة (التخطيط، والتنظيم والتنسيق،

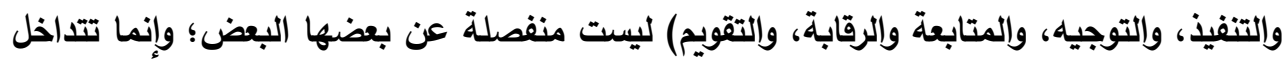
آلياتها في بعض الأحيان. وعلى سبيل المثال؛ فإن ما يقوم به أعضاء مجلس الأمناء والآباء والمعلمين في عملية التخطيط وجودة الآليات التي تم إتباعها في هذه العملية؛ يؤثر بالضرورة

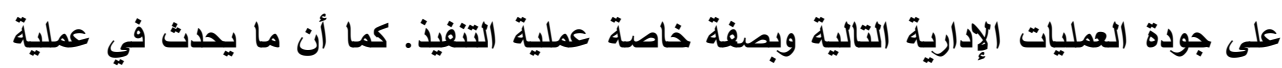
التوجيه والمتابعة والتقويم يساعد في عملية التخطيط في المرة المقبلة حيث يتم مراعاة ما واجه أعضاء المجلس من احتياجات ومعوقات أثناء أدائهم لمسئولياتهم وتنفيذهم لأنشطة المسئولية. 


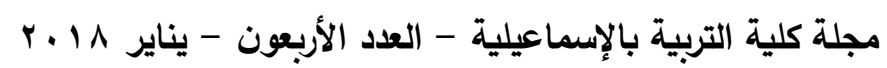

أيضاً فإن الجودة التي تمت بها آليات التوجيه، والمتابعة والرقابة تؤثر على النتائج النهائية التي تتوصل إليها عملية التقويم. وفي هذا الإطار فإنه من الضروري أن تتم آليات الوظائف أو العمليات الإدارية الستة بمشاركة

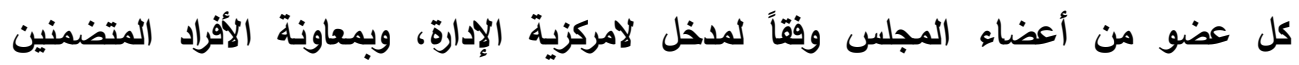

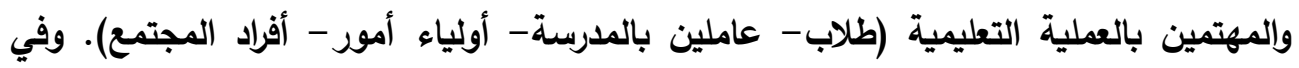

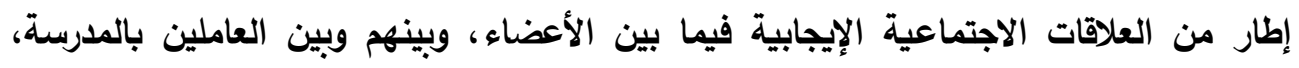
وفيما بينهم وبين أفراد المجتمع الخارجي، والذي يعزز تفعيل هذه الآليات؛ ومن ثم يؤدي إلى لئى تفعيل هذه المجالس وتغلبها على معوقاتها. رابعا: متطلبات تنفيذ الآليات المقترحة يتطلب تنفيذ الآليات المقترحة السابقة ما يأتي:

ا - الحاجة إلى تفعيل القرارات الوزارية.

ץ- وضع خطط متكاملة لاعم المشاركة المجتمعية وخدمة المجتمع وذلك لتفعيل العلاقة التبادلية بين المدرسة والمجتمع. r- وضع معايير عامة ونوعية مختلفة كعلامات مرجعية فاصلة من أجل تقييم أداء العمل ولئ بالمجلس. ؟ - إثراك الطلاب في تنفيذ الأنشطة التي تخدم بها المدرسة المجتمع.

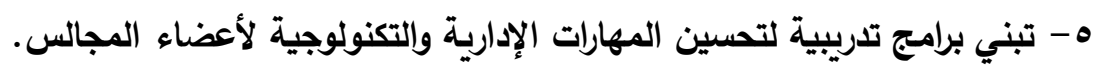
צ- تزويد المدرسة بقاعدة بيانات مكتملة تضم بيانات عن المؤسسات المجتمعية وأفراد المجتمع التي يمكن أن يستفيد المجلس من مساهماتهم. - V توفير الاعتمادات النلازمة لتنفيذ أنشطة المجلس. خامساً: صعوبات تنفيذ الآليات المقترحة ووسائل التغلب عليها توفيا ا - قلة كفاية الموارد اللازمة للتففيذ. ويمكن التغلب عليها من خلال مرحلية تنفيذ الأنثطة بما يساعد على التغلب على نقص الموارد المالية، ووضع وتنفيذ خطة لتنمية الموارد الذاتية للمجلس. ץ- القصور في الإعداد والتهيئة الإدارية لأعضاء المجالس بما يعوق سير العمليات

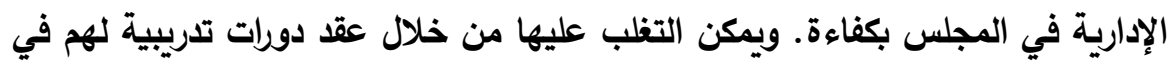


دراسة إثنوجرافية لمجالس الأمناء والآباء والمعلمين ---------- د / هند سيد أحمد

مجال الإدارة، واختيار الأعضاء ذوي الخبرات الإدارية، وخلق مناخ للتفكير الاستراتيجي بين أعضاء المجلس.

r- ندرة توافر ثقافة المسئولية تجاه المجتمع للأعضاء أو أطراف المشاركة. ويمكن التظلب

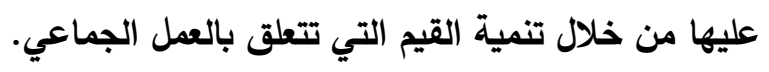

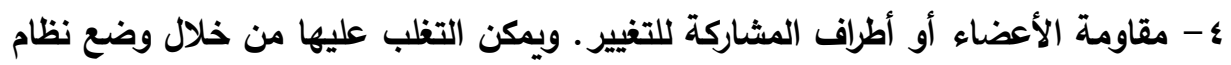

للتقييم والمتابعة يتصف بإجراءات واضحة ومعلنة، واتخاذ إجراءات تصحيحية عند وجود

$$
\text { انحرافات في الأداء. }
$$




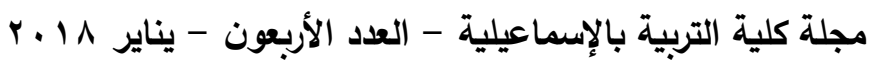

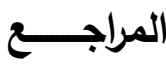

ابتسام الجعفراوي ( • • (Y). المسئولية الاجتماعية للمؤسسات الحكومية وغير الحكومية في مكافحة

الفقر في ضوء خصائص واحتياجات الأسر الفقيرة. المؤتمر السنوي الحادي عشر -

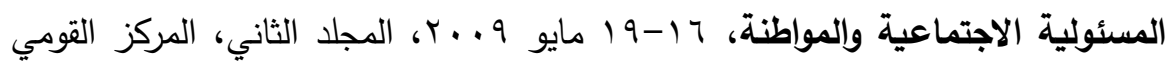
للبحوث الاجتماعية والجنائية، القاهرة.

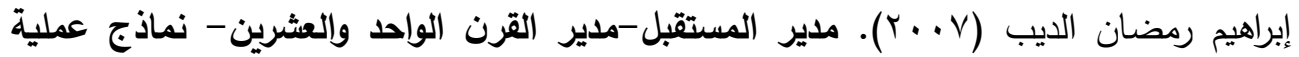
لمديرين وقادة معاصرين. مؤسسة أم القرى للترجمة والتوزيع، المنصورة.

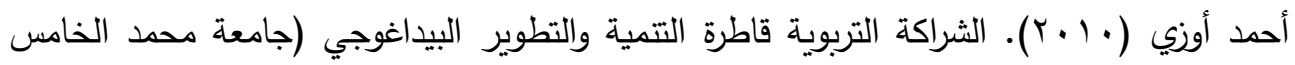

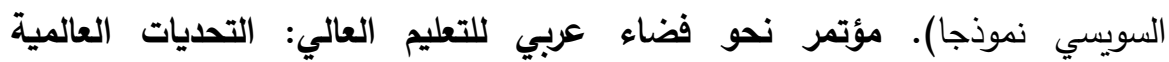
والمسؤوليات المجتمعية، أعمال المؤتمر الإقليمي العربي حول التعليم العالي، القاهرة اس اس

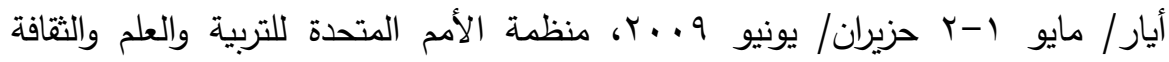
UNESCO

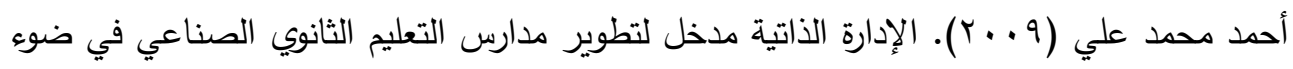
التحديات المعاصرة. رسالة دكتوراه غير منشورة، قسم أصول التربية، كلية البنات للآداب والعلوم والتربية، جامعة عين شمس.

أمنية فاروق شارودة (· ( (ץ). مشكلات مجالس الأمناء والآباء والمعلمين ومواجهتها باستخدام أسلوب حوكمة المدرسة في ضوء خبرات بعض الدول. رسالة ماجستير غير منشورة، قسم

التربية المقارنة والإدارة التعليمية، كلية التربية، جامعة بنها.

آية الله فريد ياسين (• ( ب). تحقيق اللامركزية بقوانين الإدارة المحلية وتأثيرها على تحسين البيئة

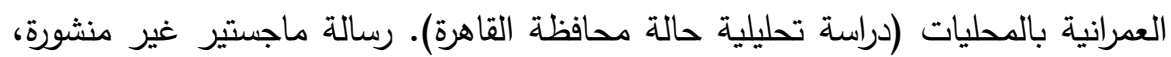
كلية الهندسة، جامعة القاهرة.

إيمان محمد عيسوي (11) (1). تطوير إدارة المدارس التجريبية الرسمية للغات في ضوء مدخل اللامركزية في جمهورية مصر العربية. رسالة ماجستير غير منشورة، قسم أصول التربية، معهد الدراسات التربوية، جامعة القاهرة. 


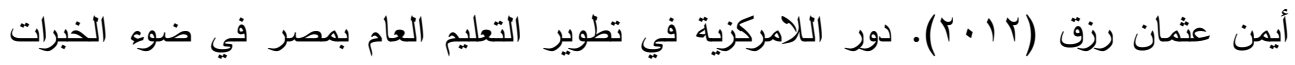

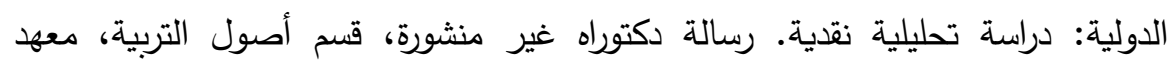
الدراسات والبحوث التربوية، جامعة القاهرة.

بيتر ف. دروكر (·( • (ب). تحديات الإدارة في القرن الحادي والعشرين. (ترجمة) توفيق علي منصور . المركز القومي للترجمة، القاهرة.

جورج عون (·(r). الالتزام الاجتماعي للطلبة الجامعيين: تجربة جامعة القديس يوسف في بيروت. مؤتمر نحو فضاء عربي للتعليم العالي: التحديات العالمية والمسؤوليات

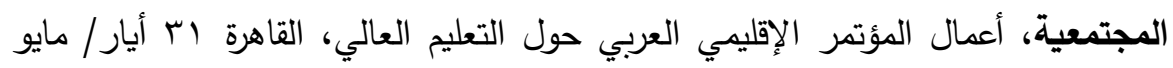

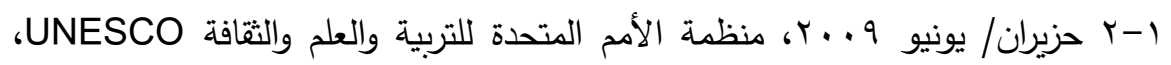
مكتب اليونسكو الإقليمي للتربية في الدول العربية، بيروت، لبنان البنان.

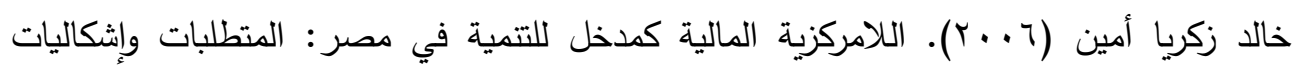
التطبيق. مجلة النهضة، مجل، ع ا، كلية الاقتصاد والعلوم السياسية، جامعة القاهرة.

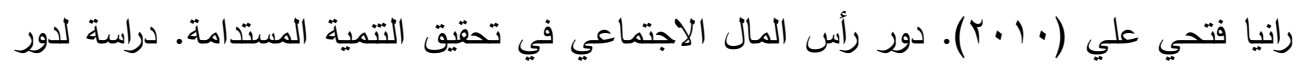
المنظمات غير الحكومية في تطوير رأس المال الاجتماعي لتتمية مدينة بورسعيد. رسالة ماجستير غير منشورة، قسم الاجتماع، كلية الآداب، جامعة عين شمس.

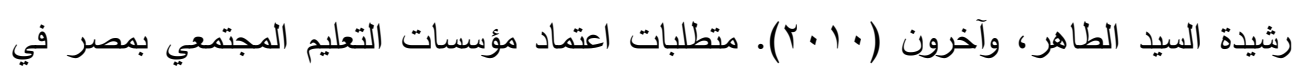
ضوء معايير الهيئة القومية لضمان جودة التعليم والاعتماد. المؤتمر الدولي السابع (التعليم

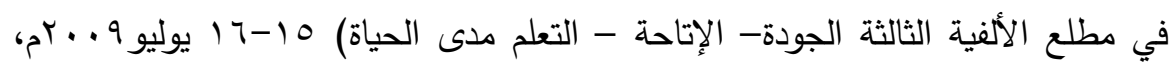

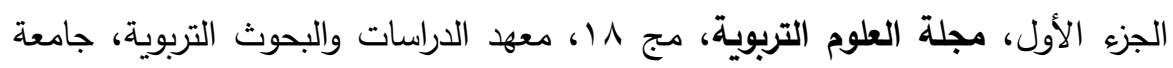
القاهرة.

روبرت إيمرسون، وآخرون (• ( • ( ). البحث الميداني الإثنوجرافي في العلوم الاجتماعية. (ترجمة)

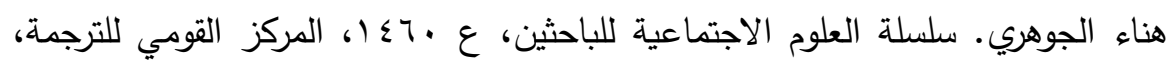
الجيزة.

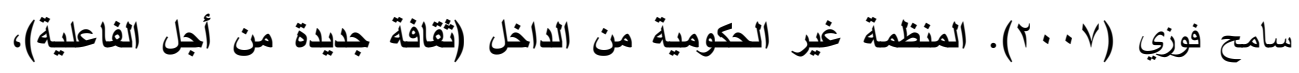
كراسات علمية، سلسلة غير دورية تعني بالاتجاهات العلمية الحديثة. المكتبة الأكاديمية، الجيزة.

$r v$. 


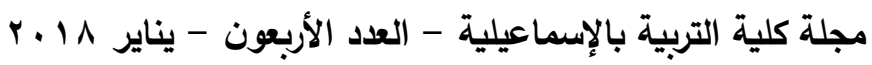

سامر عبد الله هداش (· (Y). نموذج مقترح لعلاقة الثقافة التظيمية بفرق العمل ذاتية الإدارة بالتطبيق على الثركات السعودية المنتجة في جدة. رسالة دكتوراه غير منشورة، قسم إدارة الأعمال، كلية التجارة، جامعة عين شمس.

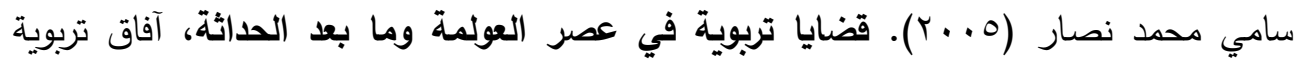
متجددة. الدار المصرية اللبنانية، القاهرة.

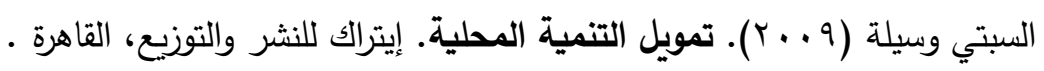

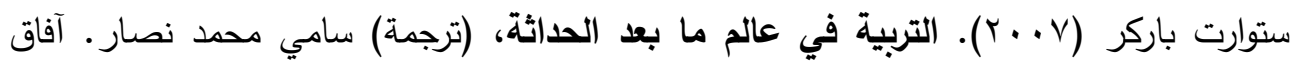
تربوية متجددة، الدار المصرية اللبنانية، القاهرة.

سماح رشاد حسن (ع . . ب). دور مجالس الآباء والمعلمين في المدارس الابتدائية (دراسة تقويمية). رسالة ماجستير غير منشورة، قسم أصول التربية، كلية البنات للآداب والعلوم والتربية، جامعة عين شمس. سماح زهران (• ( + ). المسئولية المجتمعية إزاء أشكال العنف ضد الأطفال دراسة تحليل محتوى.

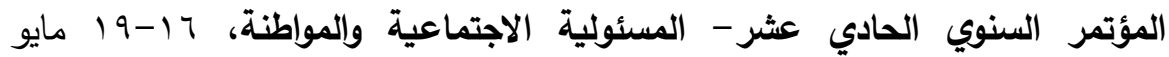
9 . . r، المجلد الثاني، المركز القومي للبحوث الاجتماعية والجنائية، القاهرة. سناء مبروك (· ( • ( ). المسئولية الاجتماعية والمواطنة دراسة أنثروبولوجية لقيم الولاء والانتماء في

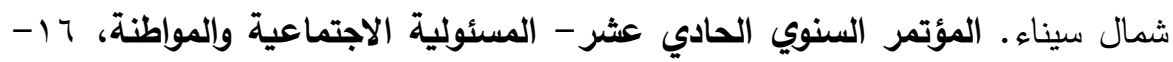
9 1 مايو 9 . . ب، المجلد الأول، المركز القومي للبحوث الاجتماعية والجنائية، القاهرة.

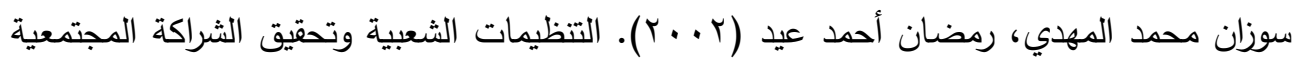
في التعليم دراسة مقارنة في الولايات المتحدة الأميريكية وانجلترا وبلجيكا وإمكانية الإفادة منها في مصر • مجلة التربية والتنمية، السنة • ا، عجr، المكتب الاستشاري للخدمات

$$
\text { التربوية. }
$$

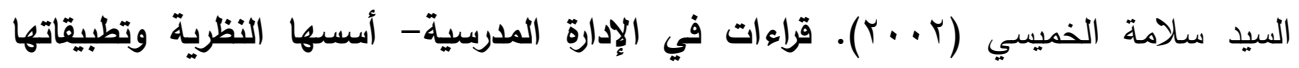
الميدانية والعملية. دار الوفاء للطباعة والنشر، الإسكندرية.

شيفا لوهاني، وآخرون (· ( • ( ). التعليم الابتدائي الثامل في نيبال: الوفاء بالحق في التعليم. مجلة مستقبليات 100، مج، ع، عَ، مركز مطبوعات اليونسكو (منظمة الأمم المتحدة للتربية

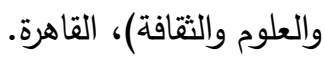


دراسة إثنوجرافية لمجالس الأمناء والآباء والمعلمين --------- د / هند سيد أحمد

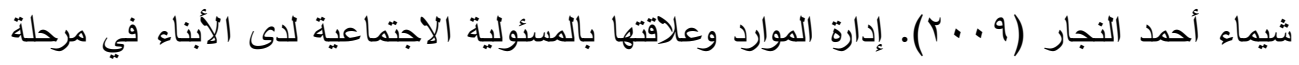
المراهقة. رسالة ماجستير غير منشورة، قسم إدارة المنزل والمؤسسات، كلية الاقتصاد

$$
\text { المنزلي، جامعة المنوفية. }
$$

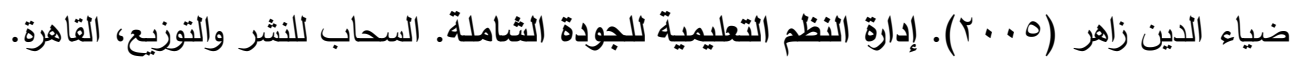
عبد الحميد عبد الفتاح المغربي (9 . . r). أنماط الثخصية الإدارية وقياسها - كيف تبني وتنمي شخصيتك. المكتبة العصرية للنشر والتوزيع، المنصورة.

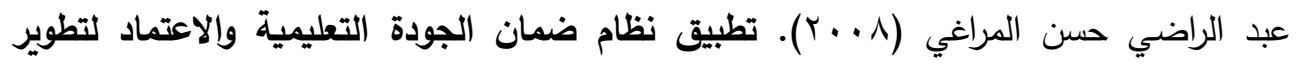
التعليم الجامعي وقبل الجامعي. القاهرة، دار الفكر العربي.

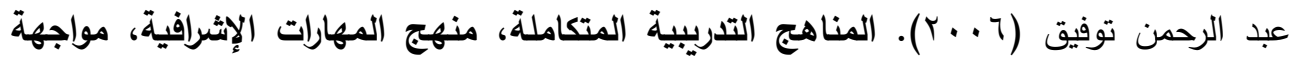
ضغوط العمل، طء. مركز الخبرات المهنية للإدارة - بميك، القاهرة.

عبد الرحمن عبد الرحيم الخطيب (r . . ץ). واقع دور مجالس الآباء في تدعيم العملية التربوية في

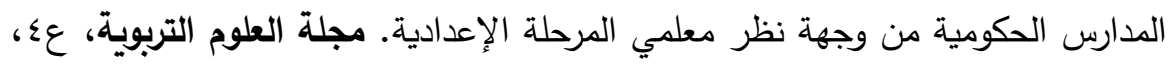

معهد الدراسات والبحوث التربوية، جامعة القاهرة.

عبد علي حسن (999 (1). برنامج مقترح لتفعيل أدوار أولياء الأمور في العملية التعليمية/التعلمية.

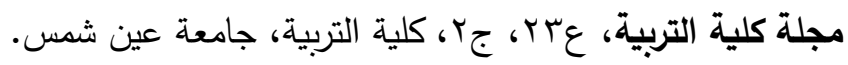

عفاف عبد القوي (· (ب). المسئولية الاجتماعية للمؤسسات الصناعية في التدريب- دراسة

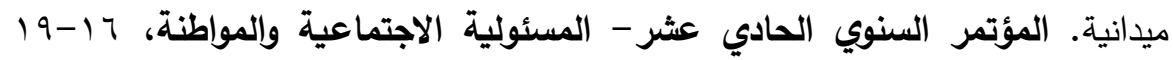
مايو 9 ×. . Y، المجلد الثاني، المركز القومي للبحوث الاجتماعية والجنائية، القاهرة. علي جلبي (• ( ·). المواطنة والمشاركة وانعكاساتها في حياتتا اليومية. المؤتمر السنوي الحادي

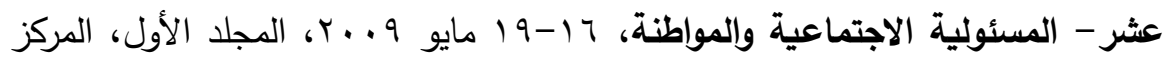
القومي للبحوث الاجتماعية والجنائية، القاهرة. علي صالح جوهر ، محمد حسن جمعة (· ( ·). الثراكة المجتمعية وإصلاح التعليم- قراءة في الأدوار التربوية لمؤسسات المجتمع المدني، المكتبة العصرية للنشر والتوزيع، المنصورة. علي ليلة (· ( + ( ). المسئولية الاجتماعية - تعريف المفهوم وتعيين بنية المتغير • المؤتمر السنوي

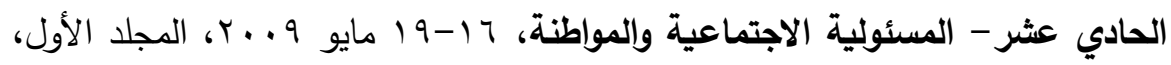
المركز القومي للبحوث الاجتماعية والجنائية، القاهرة. TVY 


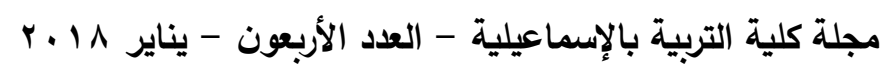

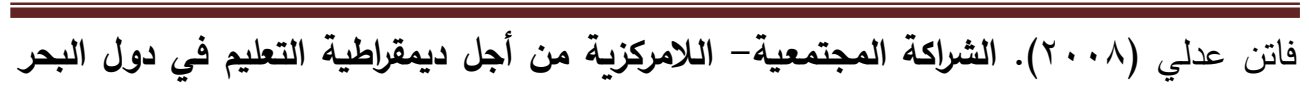
المتوسط. المكتب الجامعي الحديث، الإسكندرية.

فردوس عبد الحليم، فريد عباس (ء79 (1). تتظيم مجلس الآباء والمعلمين. المؤتمر السنوي الرابع لمجالس الآباء والمعلمين بالجمهورية. وزارة التربية والتعليم، القاهرة.

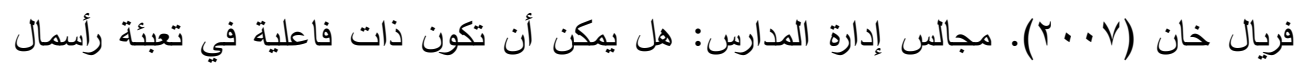

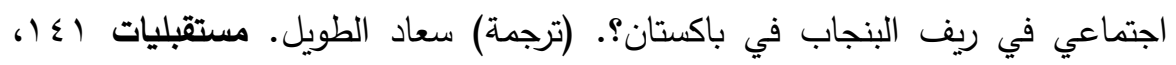
مجلr، ع ا، مركز مطبوعات اليونسكو، القاهرة.

فريد راغب النجار (999 19). المديرون والمنظمات، مدخل تجريبي لتنمية المهارات. مؤسسة شباب

$$
\text { الجامعة، الإسكندرية. }
$$

فؤاد أحمد حلمي (991 (1). مدخل المساءلة والمحاسبية التعليمية. دار سفير ، القاهرة.

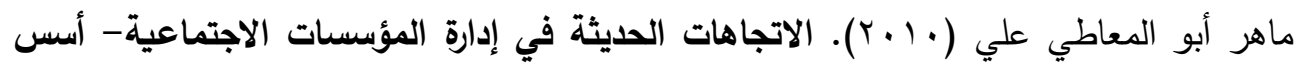
نظرية ونماذج تطبيقية. المكتب الجامعي الحديث، الإسكندرية.

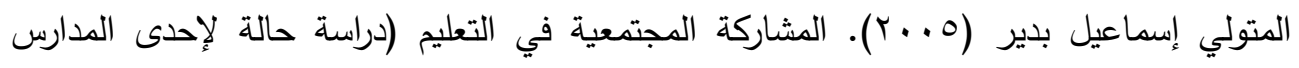
التعاونية). مجلة كلية التربية، ع9ه، جاعل، كلية التربية، جامعة المنصورة.

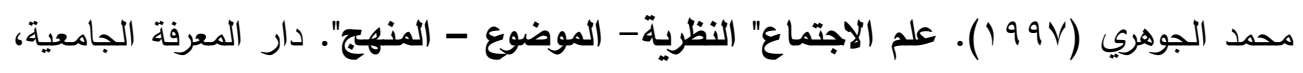
الإسكندرية.

محمد حسنين العجمي (0 . ب). المشاركة المجتمعية لتفعيل مدخل الإدارة الذاتية لمدارس التعليم

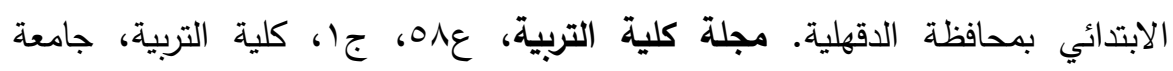

$$
\text { المنصورة. }
$$

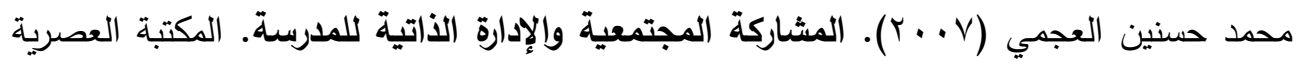

$$
\text { للنشر والتوزيع، المنصورة. }
$$

محمد سعد، ومنال زكريا (• ( • ( ). العلاقة بين أبعاد التفاعلات الأسرية وكل من الثعور بالانتماء

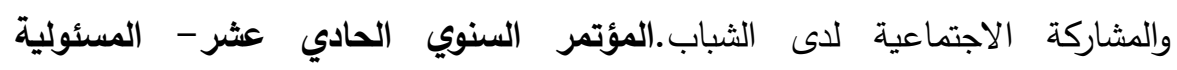

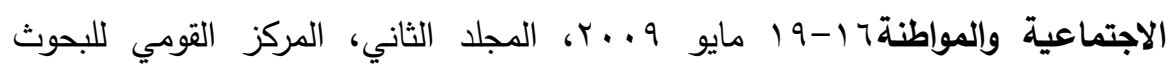
الاجتماعية والجنائية، القاهرة. 
دراسة إثنوجرافية لمجالس الأمناء والآباء والمعلمين --------- د / هند سيد أحمد

محمد شفيق (r . . r). البحث الاجتماعي، الأسس والخطوات المنهجية. المكتب الجامعي الحديث،

الإسكندرية.

محمد عاطف شاهين (• (Y). تفعيل المشاركة المجتمعية في تتمية السلوك الاجتماعي المرتبط بالبيئة لاى تلاميذ الددرسة الابتدائية في المناطق العشوائية. رسالة ماجستير غير منشورة،

قسم العلوم الإنسانية، معهد الدراسات والبحوث البيئية، جامعة عين شمس.

محمد محمد إبراهيم (1) (1). إعادة الهيكلة الإدارية للمؤسسات العربية للتعامل مع التحديات والأزمات المعاصرة في ضوء إدارة تداعيات الأزمة المالية العالمية. الدار الجامعية،

$$
\text { الإسكندرية. }
$$

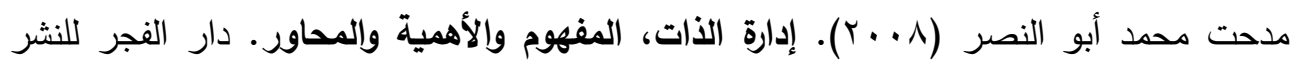

$$
\text { والتوزيع، القاهرة. }
$$

مديرية التربية والتعليم (T (1 ب). إحصائية بأعداد المدارس بمحافظة المنوفية للعام الدراسي

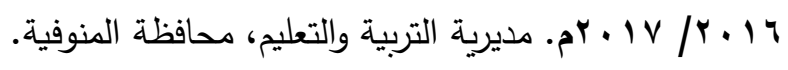

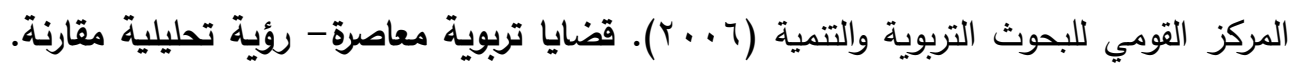

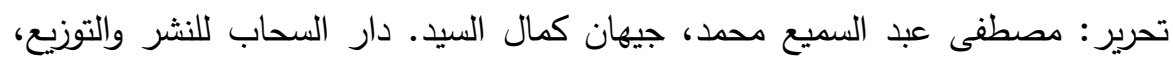

$$
\text { القاهرة. }
$$

المركز القومي للبحوث التربوية والتتمية (191 (1). وزراء التعليم في مصر وأبرز إنجازاتهم

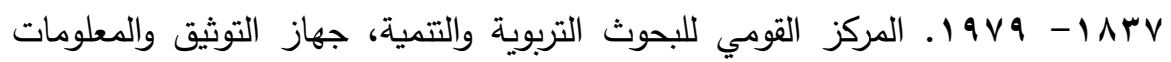

$$
\text { التربوية، القاهرة. }
$$

مصطفى حسين باهي (999 (1). المعاملات العلمية والعملية بين النظرية والتطبيق. مركز الكتاب

$$
\text { للنشر ، القاهرة. }
$$

مها عبد الحميد السنباوي (11 + ب). لامركزية التعليم كمدخل لتطوير التعليم الأساسي مع دراسة الحالة المصرية. رسالة ماجستير غير منشورة، قسم الإدارة العامة، كلية الاقتصاد والعلوم السياسية، جامعة القاهرة.

ميرفت حافظ مصطفى (9 9 . r). أساليب الربط بين المدرسة والمجتمع المحلي في ضوه خبرات بعض الدول الأجنبية. رسالة ماجستير غير منشورة، قسم أصول التربية، معهد الدراسات والبحوث التربوية، جامعة القاهرة. 


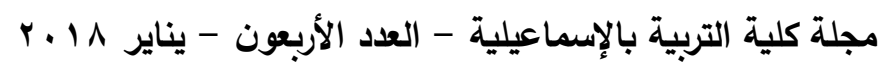

نادية محمد عبد السلام (ץ... م).الإحصاء الوصفي في العلوم النفسية والتربوية.مكتبة الأنجلو المصرية،القاهرة.

نبيل سعد خليل (9 . . ب). أنماط الإدارة التعليمية- أصولها - وتطبيقاتها. دار الفجر ، القاهرة.

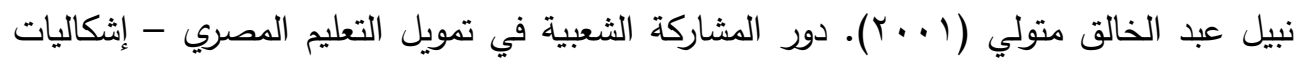

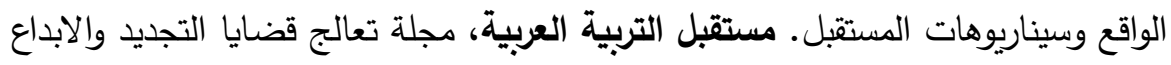

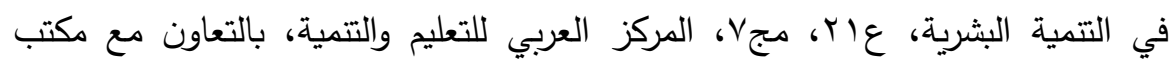
التربية العربي لدول الخليج، جامعة المنصورة، المكتب الجامعي الحديث. نجدة إبراهيم سليمان (99V (19). تطوير الإدارة المحلية في التعليم رؤية مستقبلية. رسالة دكتوراه غير منشورة، قسم أصول التربية، معهد الدراسات والبحوث التربوية، جامعة القاهرة.

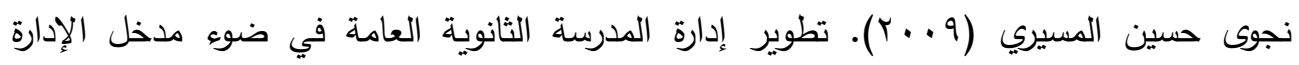
الذاتية. رسالة دكتوراه غير منشورة، قسم أصول تربية، معهد الدراسات والبحوث التربوية، جامعة القاهرة.

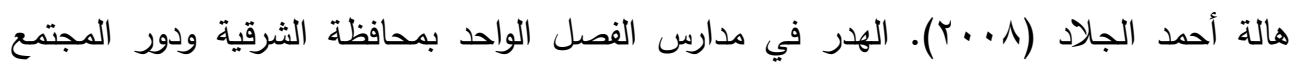
المحلي في مواجهته (تصور مقترح). رسالة ماجستير غير منشورة، قسم أصول التربية، معهد الدراسات والبحوث التربوية، جامعة القاهرة. هناء محمود القيسي (• ( • ( ). الإدارة التربوية، مبادئ- نظريات- اتجاهات حديثة. دار المناهج للنشر والتوزيع، عمان، الأردن.

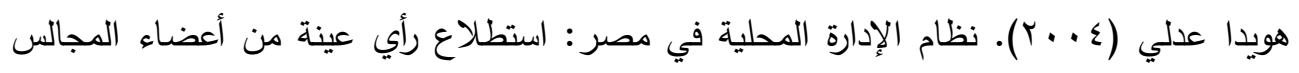

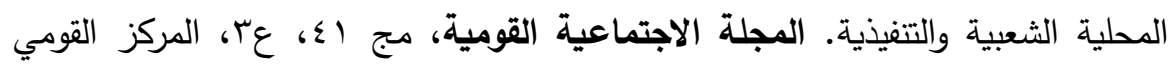
للبحوث الاجتماعية والجنائية، القاهرة.

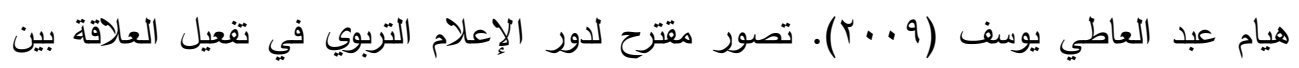

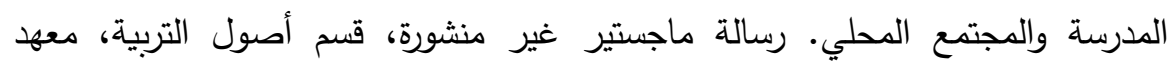
الدراسات والبحوث التربوية، جامعة القاهرة.

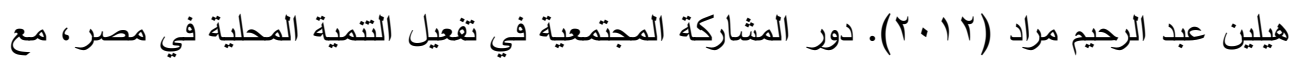
دراسة حالة محافظة الإسماعيلية. رسالة دكتوراه غير منشورة، قسم الإدارة العامة، كلية الاقتصاد والعلوم السياسية، جامعة القاهرة. 
وداد على الرحمن، شهيرة أسامة (· (Y. (Y). جامعة الأحفاد للبنات- مابعد الامتياز الأكاديمي: المسؤولية الاجتماعية والمشاركة المدنية، مؤتمر نحو فضاء عربي للتعليم العالي:

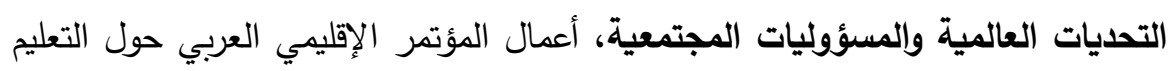

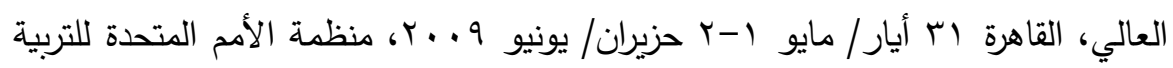

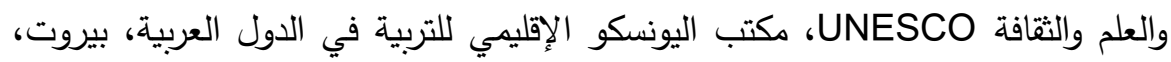

لبنان

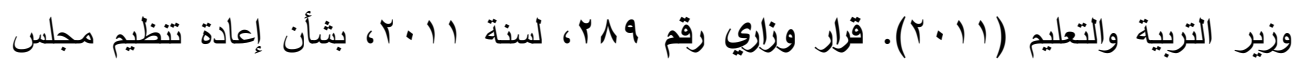

الأمناء والآباء والمعلمين. مكتب الوزير، وزارة التربية والتعليم، جمهورية مصر العربية.

وفاء زكي بثاي (Y Y (Y). صيغة مقترحة لتحقيق المشاركة المجتمعية وتفعيل مجالس الأمناء

بالمدارس المصرية في ضوء تجارب بعض الدول. رسالة دكتوراه غير منشورة، قسم التربية

$$
\text { المقارنة، كلية التربية، جامعة الإسكندرية. }
$$

Bando, Rosangela (2010). The Effect of School Based Management on Parent Behavior and The Quality of Education in Mexico. A Dissertation of Doctor of Philosophy, University of California, Berkeley.

Cheng, Yin Cheong \& Chan, Man Tak (2000). Implementation of SBM: A Multi- Perspective Analysis of The Case of Hong Kong. International Review of Education, Vol. 46, Issue 3-4, Kluwer Academic Publishers, Printed in Netherlands.

Fullan, M. \& Watson, N. (2000). School Self-Management: Reconceptualizing to Improve Learning Out comes. School Effectiveness and School Improvement, Vol. 11, No. 4.

Hollaway, John H. (2000). The Promise and Pitfalls of SBM. Educational Leadership . Vol. 57, No.7.

Lane, John J. (1992). Instructional Leadership and Community:A perspective on School Based Management. Theory into Practice, Vol.30, No.2, Spr.1991. Academic Search Complete, EJ433780.

Leroy, Reine Carmel. (2002). School-Based Management in Haiti: Committee Members' Perceptions of Benefits, Disadvantages, Constraints And Facilitators, Doctor of Education. Dissertations from ProQuest. 


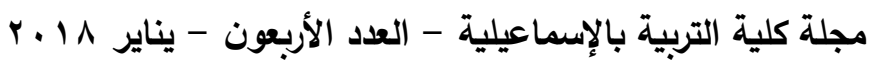

http://scholarlyrepository.miami.edu/dissertations/1874 Retrieved in $19 / 4 / 2016$

Majhanovich, Suzanne (2008). Decentralization of Education: Promising Initiative or Problematic Notion?. Ph D., University of Western Ontario, Canada. Community Participation, Decentralization and Education to Democracy in The Mediterranean Area $\backslash$ Countries, Edited By: Adly Faten, ASCHRD.

Michael, Podgursky\& Dale, Ballou (2001). Personal Policy in Charter School. U.S.A., Washington, Dc.

Noguera, Pedro. A. (2002). Beyond Size: The Challenge of High School Reform. Educational Leadership, Vol. 59, Issue 5.

Ouchi, W.G.\& Segal, L.G. (2003). Making Schools Work. A Revolutionary plan to Get Your Children The Education They Need. New York, Siman \& Schuster.

Pang, Nicholas S. K. (2006) . Managing School Change through SelfEvaluation in The Era of Globalization . Paper Presented at The 19 Annual World International Congress for School Effectiveness and Improvement, ICSEI, Florida.

Parker, Sharon K (2007). That Is My Job: How Employees' Role Orientation Affects Their Job Performance. Human Relations, Vol. 60, No. 3.

Smith, Richard \& Clinton, Janet (2001). Evaluating The Evaluators • New Zealand Education Review_, Wellington, No. 13.

Van De Valk, Lawrence J.; Constas, Mark A. (2011). A Methodological Review of Research on Leadership Development and Social Capital: Is There a Cause and Effect Relationship?. Adult Education Quarterly: A Journal of Research and Theory, Vol.61, No.1.

Wells, Ryan S.; et al. (2011). Why Do More Women than Men Want to Earn a Four-Year Degree? Exploring the Effects of Gender, Social Origin, and Social Capital on Educational Expectations. Journal of Higher Education, Vol. 82 , Issue 1. 
دراسة إثنوجرافية لمجالس الأمناء والآباء والمعلمين --------- د / هند سيد أحمد مستخلص

استهدفت الدراسة تطوير إدارة مجالس الأمناء والآباء والمعلمين في ضوء مدخل لامركزية الإدارة، وقد استخدمت المنهج الإثنوجرافي، وطبقت بطاقة المقابلة على عينة من أعضاء مجالس الأمناء والآباء والمعلمين، معتمدة على الملاحظة بالمعايثة، بهدف تحديد واقع تحقيق مبادئ مدخل لامركزية الإدارة بمجالس الأمناء والآباء والمعلمين ببعض المدارس، وقد توصلت الدراسة التحليلية النظرية إلى تحديد مسئوليات مجالس الأمناء والآباء والمعلمين، والمعوقات التي تحول دون تحقيق هذه المسئوليات، ومعظمها معوقات إدارية، كما أشارت نتائج الدراسة الإثنوجرافية إلى وجود قصور وضعف في الأسلوب الإداري لهذه المجالس مما يعوق قيامها بمسئولياتها، وقدمت الدراسة مجموعة من البائل والآليات المقترحة لتطوير إدارة مجالس الأمناء والآباء والمعلمين في ضوء مدخل لامركزية الإدارة. 


\section{Abstract}

The study was designed to develop the management of the boards of trustees, parents and teachers in light of decentralization. The ethnographic approach was used, and the interview was applied to a sample of members of boards of trustees, parents and teachers, based on the observation of coexistence in order to determining the actuality of achieving the principles of decentralization in these boards. The theoretical analysis of the study determine the responsibilities of the boards of trustees, parents and teachers, and the obstacles to the achievement of these responsibilities, Most of the obstacles were administrative, And the results of the ethnographic study found that there were deficiencies and weakness in the managerial techniques of these councils, which hamper its responsibilities, The study presented a set of suggested alternatives and mechanisms for the development of the management of boards of trustees, parents and teachers in light of decentralization. 